Corpo de provas 
Sara Miriam Goldchmit

\section{Corpo de provas}

\section{Book of Proofs}

Tese apresentada à Faculdade de Arquitetura e Urbanismo da Universidade de São Paulo para obtenção do título de Doutor

Área de concentração: Design e Arquitetura

Orientador: Prof. Dr. Silvio Melcer Dworecki 
Autorizo a reprodução e divulgação total ou parcial deste trabalho, por qualquer meio convencional ou eletrônico,

para fins de estudo e pesquisa, desde que citada a fonte.

E-mail: sara@saragold.com.br

\begin{tabular}{|c|c|}
\hline G618c & $\begin{array}{l}\text { Goldchmit, Sara Miriam } \\
\text { Corpo de provas / Sara Miriam Goldchmit. } \\
\text { São Paulo, } 2013 . \\
296 \text { p.; } 235 \text { il. }\end{array}$ \\
\hline & $\begin{array}{l}\text { Tese (Doutorado - Área de Concentração: } \\
\text { Design e Arquitetura) FAUUSP. } \\
\text { Orientador: Silvio Melcer Dworecki }\end{array}$ \\
\hline \multicolumn{2}{|c|}{$\begin{array}{l}\text { 1. Imagem (Artes) 2. Comunicação visual 3. Percepção visual } \\
\text { 4. Criação artística 5. Artes visuais (Estudo e ensino) 6. Design } \\
\text { I.Título } \\
\text { CDU } 7.04\end{array}$} \\
\hline
\end{tabular}

\section{Sara Miriam Goldchmit | Corpo de provas}

Tese apresentada à Faculdade de Arquitetura e Urbanismo da

Universidade de São Paulo para obtenção do título de Doutor

Área de concentração: Design e Arquitetura

Aprovado em:

Banca examinadora

Prof. Dr.

Instituição

\section{Assinatura}

Prof. Dr.

\section{Instituição}

Assinatura

\section{Prof. Dr.}

Instituição

Assinatura

Prof. Dr.

Instituição

Assinatura

Prof. Dr.

Instituição

Assinatura 


\section{Agradecimentos}

Ao Silvio Melcer Dworecki, pela orientação generosa e amizade que vão muito além do espaço e tempo deste doutorado, pelo compromisso com minha formação artística e humanística, por ter me proposto tantos desafios, pela disponibilidade e atenção com que conduziu este trabalho. Sou profundamente grata pelo privilégio do nosso convívio.

Ao Claudio Mubarac, pela dedicação e conhecimentos transmitidos nas aulas que cursei na pós-graduação da Escola da Comunicações e Artes, colaboração que foi fundamental para consolidar os caminhos da pesquisa, assim como a apreciação cuidadosa feita na banca de qualificação.

Ao Sérgio Régis Martins, pela participação na banca de qualificação e pelas contribuições importantes que avivaram meus diálogos com a arte contemporânea.

Aos colegas professores do Grupo de Disciplinas de Programação Visual do Departamento de Projeto da FAU-USP, pela oportunidade de ter atuado como professora nos cursos de Design e Arquitetura simultaneamente ao período de realização da tese, pelos ensinamentos e convivência sempre formadora, por todo o apoio e incentivo: Carlos Zibel, Chico Homem de Melo, Cláudio Tozzi, Clice de Toledo Sanjar Mazzilli, Daniela Kutschat Hanns, Eleida Pereira de Camargo, Feres Khoury, Gil Barros, Marcelo Bicudo, Priscila Farias, Takashi Fukushima e Vicente Gil.

Aos alunos da oitava turma do Curso de Design da FAU-USP, pelo entusiasmo com que cursaram minhas aulas de Linguagens 
Visuais, tornando a experiência docente um aprendizado. Sou grata especialmente àqueles que tiveram sua produção documentada nesta tese: Ana Carolina Presta, Caroline Ploennes, Claudio Luiz, Dream Choi, Erika Vanoni, Fernanda Abe, Fernanda Tottero e Felipe Cavalheiro dos Anjos, Isabela Costard, Isabela Monteiro Sanches, Jessica Strazzi, João Eduardo Pinhata, João Schmitt, Julia Kao Igarashi, Laraíne Roque, Leonardo Abreu, Lívia Naomi Takemura, Mateus Dal Vesco e Sabrina Duarte.

Agradeço ao Istituto Europeo di Design, faculdade que tem me possibilitado exercer a prática docente com ampla liberdade. Sou grata aos alunos do IED pela confiança e ao corpo docente pelo compartilhamento de vivências em torno do ensino do design.

Sou grata aos funcionários da Secretaria da FAU Maranhão, do Departamento de Projeto da FAU-USP, do Laboratório de Produção Gráfica da FAU-USP, das Bibliotecas da FAU-USP e FAU Maranhão, por todo o seu apoio.

A Regina Stocklen, pelo cuidado na revisão dos textos originais.

Aos colegas mestrandos e doutorandos da área de Design e Arquitetura, pelas interlocuções em diversos momentos de nossos percursos: Ana Paula Campos, Elizabeth Romani, Eunice Liu, Gil Tokio, Iara Pierro de Camargo e Rodrigo Araújo.

A Adriana Ferla, Mariana Dupas, Mirella Marino e Renata Bueno por sua companhia, amizade e pelas conversas sempre estimulantes que temos ao compartilhar esse território específico na fronteira entre arquitetura, design, arte e ensino.

A Marcelo Queiroz, por me ensinar sobre coragem e determinação, por seu amor, incentivo e cumplicidade na construção conjunta do projeto das nossas vidas.

Aos meus pais e irmãos, porque sou parte de vocês e vocês são parte de mim. 
O fim da atividade artística não é a obra, mas a liberdade.

Octavio Paz 


\section{Abstract}

The present research aims to create a collection of visual artworks and document its creation process, while also focusing on developments for the teaching of visual languages in the field of Design Studies. The images were created from observation, reflection, and gesture and took shape through a number of practices including photography, scanning, collage, digital manipulation, drawing, and print. An investigation into the genesis of the process was made possible through the association of the creative act and a deliberation on its praxis: theory became practice, and practice turned into reflection. The first part of this thesis offers figurative sequences and accounts by the author, which convey the motivations and meanders of her creation process. That material was subsequently confronted to theoretical concepts and contemporary visual works. The second part displays visual products created by the author's students in the context of an undergraduate Design class, and includes her accounts regarding this academic experience. As a document of the trajectories, detours, difficulties, and achievements experienced throughout the reflective practice in the construction of visual languages, Book of Proofs suggests options and offers support for teaching these processes.

\section{Keywords}

Image, photography, collage, contemporary art, visual design, print, visual arts teaching, perception, testimonies,

creative processes.

\section{Resumo}

O objetivo desta pesquisa é a criação de um corpo de trabalhos visuais e registro de seu processo criativo, tendo em vista desdobramentos didáticos para o ensino de linguagens visuais no campo do Design. Imagens foram geradas a partir da observação, do pensamento e do gesto, e ganharam visibilidade através de procedimentos como fotografia, escaneamento, colagem, manipulação digital, desenho e impressão. $\mathrm{O}$ ato criador, aliado à reflexão sobre esse fazer, permitiu a investigação sobre a gênese deste processo: a teoria é uma prática, o fazer é um pensar. A primeira parte da tese expõe sequências figurativas em simultaneidade com depoimentos, ambos produzidos pela autora, onde se apresentam as motivações e os meandros deste processo criativo, cotejados com conceitos teóricos e com a produção contemporânea da visualidade. Na segunda parte, produtos visuais realizados pelos alunos da autora, no âmbito de uma disciplina de graduação em Design, são apresentados com os relatos sobre essa experiência docente. Corpo de provas, enquanto documento dos trajetos, desvios, dificuldades e conquistas vivenciados na prática reflexiva da construção de linguagens visuais, fornece subsídios e aponta possibilidades didáticas para seu ensino.

\section{Palavras-chave}

Imagem, fotografia, colagem, arte contemporânea, design visual, impressão, ensino de artes visuais, percepção, depoimento, processos criativos. 
17 Introdução

\section{Embates}

22 Ventos

Desenhos de observação

Vazios

Cenas

Corpos de água

Comprovantes

Cor-luz

\section{Fluxos}

273 Lista de imagens

289 Referências bibliográficas 


\section{Introdução}

A questão desenvolvida neste trabalho vem sendo amadurecida desde os anos de graduação na Faculdade de Arquitetura e Urbanismo da Universidade de São Paulo. Ali comecei a definir interesses que direcionaram meu percurso por três vertentes complementares: a prática profissional de projetos visuais no campo do Design, uma investigação tácita sobre a poética da visualidade, especialmente nas linguagens do desenho e fotografia e, mais recentemente, a atuação didática como professora em faculdades de Design e Arquitetura.

$\mathrm{Na}$ intersecção destas três vertentes - design, arte e ensino -, surge a motivação para realizar esta pesquisa de Doutorado. Entendo a arte como um exercício de liberdade de pensamento e ação, que informa e oxigena a maneira de projetar em arquitetura e design e, sobretudo, emancipa aquele que projeta. O âmago do meu trabalho se constitui e se renova nas contaminações entre arte e design. A pergunta - como criar imagens? - intimamente respondida no fazer específico de cada projeto, visto que não há regras dadas a priori, converte-se em um desafio a ser explicado aos alunos, a partir do momento em que começo a atuar também como professora. À reflexão sobre o fazer somou-se a necessidade de refletir sobre o ensinar a fazer.

Os conjuntos de ensaios visuais realizados em simultaneidade com depoimentos sobre o processo criativo constituem o corpo da tese. A natureza metodológica da prática reflexiva dá-se em consonância com os procedimentos que caracterizam a minha trajetória híbrida como designer, artista e professora. 
Depoimentos e imagens - rastros do gesto criador - conformam este livro como plataforma, em permanente estado de inacabamento, à maneira de um corps d'ouvrage ${ }^{1}$. Embates, primeira parte desta tese, acolhe os ensaios sobre minhas experiências figurativas ${ }^{2}$ realizados em sincronia com depoimentos sobre o processo de criação. Em Fluxos, segundo momento do trabalho, estão as imagens produzidas por meus alunos durante uma disciplina de graduação em Design. Observei o meu percurso criativo e, quase simultaneamente, coloquei à prova minhas percepções e procedimentos em uma situação coletiva de ensino. Desta forma, alimento o debate sobre a contiguidade que há entre o trabalho criativo do professor e do aluno.

As imagens têm um papel central nesta pesquisa. Procuro validar a manifestação visual como forma autônoma de pensamento, ao dispor as imagens lado a lado com textos que as complementam, mas não as traduzem. O conceito de prova entendida como documento, testemunho ou experiência é também fundamental no corpo da tese. Imagens fotográficas são provas de um determinado fato e podem ser postas à prova: até onde uma imagem resiste, e o que possibilita, ao ser ampliada, distorcida, cortada, desfocada? Imagens digitais, fluidas, em função de sua natureza imaterial, podem assumir o tamanho da página impressa, de um cartaz, da tela - do suporte, enfim. Estas se adaptam e, ao mesmo tempo, definem este objeto-livro. Não há legendas, pois não há obras: as imagens são provas de uma ação.

Nos depoimentos, a busca de conceitos teóricos que os embasassem e circunstanciassem, transbordou naturalmente para outras áreas do conhecimento. Este trabalho também registra o que atualmente significa estar à deriva entre os signos da cultura, seja costurando linhas de errância entre autores diversos, seja colecionando imagens, impressões ou dialogando com outras obras de arte, cinema, literatura... Deriva que resulta na formação de um repertório estimulante ao pensamento e à participação criativa na dança das imagens que povoam o mundo contemporâneo.

${ }^{1}$ A expressão corps d'ouvrage significa o miolo do livro, da primeira página à última, antes de receber a capa. Disponível em: $<\mathrm{http}$ //www.bibliopolis.net/ glossaire/glo_aaz.htm>, em francês. Acesso em 5/10/2013. O miolo do livro é conformado pelas folhas impressas e dobradas de acordo com a imposição das páginas em cadernos. Os cadernos dobrados são reunidos na ordem correta (processo de alceamento), o bloco do livro é então costurado e refilado, ficando pronto para ser revestido pela capa. (HASLAM, 2010).

2 "O $\mathrm{O}$ ato de figurar [...] é aquele de conceber imagens de quaisquer naturezas e torná-las visíveis. [...] pensamento figurativo, plástico ou estético são usados como sinônimos" (DWORECKI, 1998, p. 201). “[...] existe um pensamento plástico como existe um pensamento matemático ou um pensamento político [...]" (FRANCASTEL, 1993, p. 3). 


\section{Embates}


Ventos

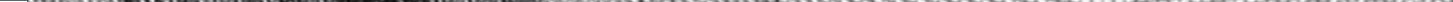




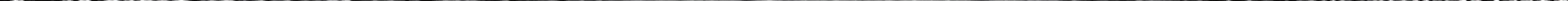


H.
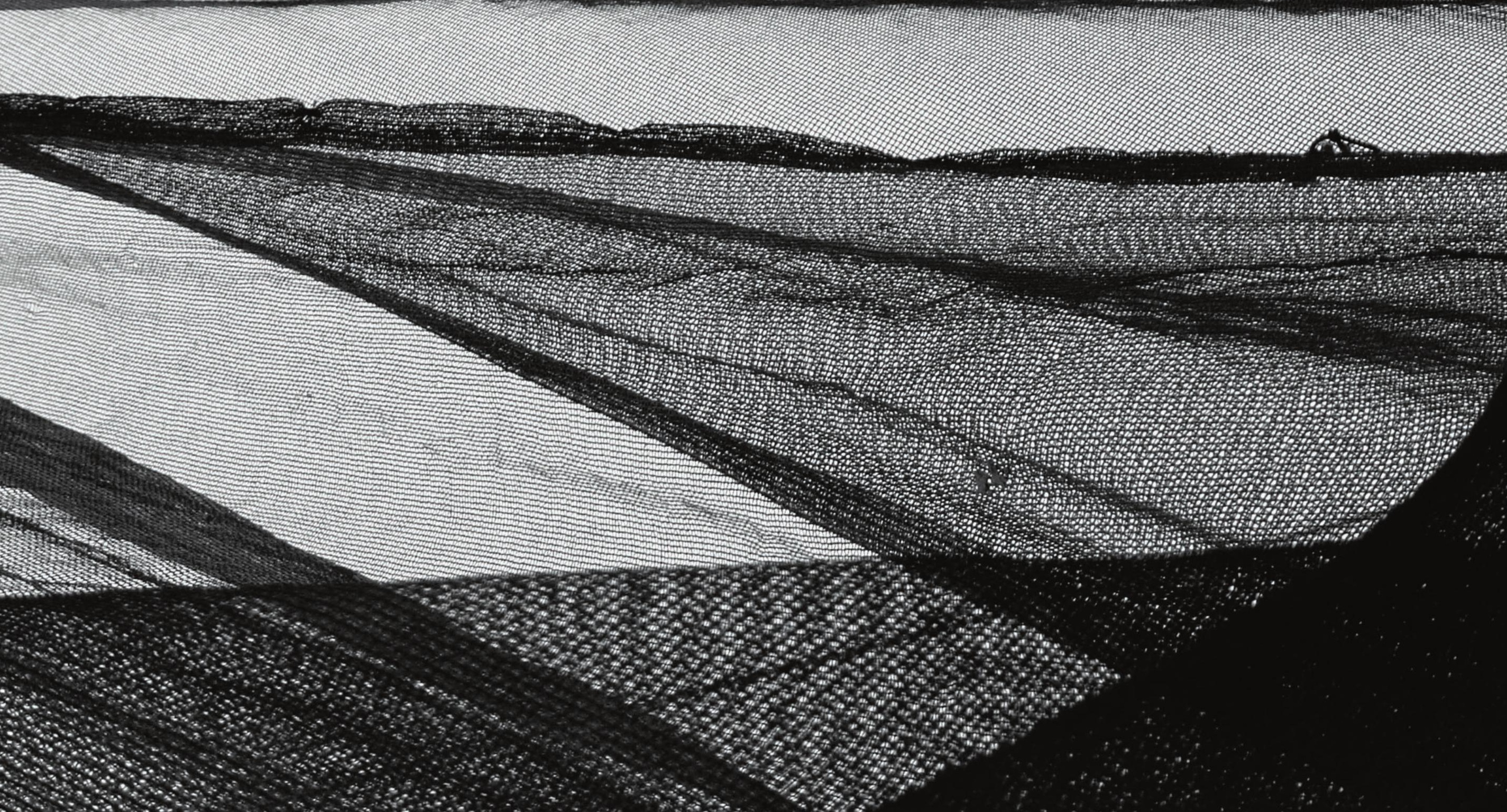

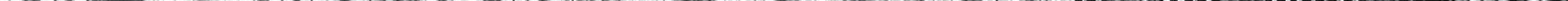


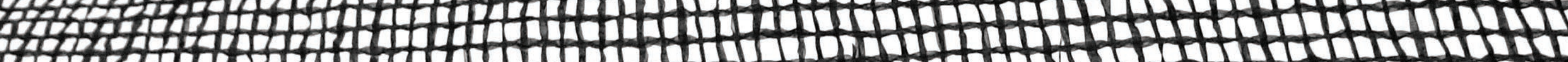

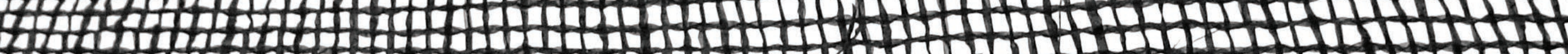

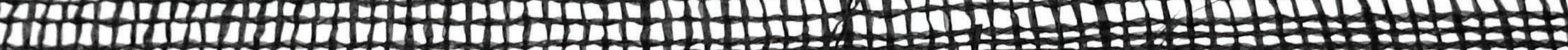

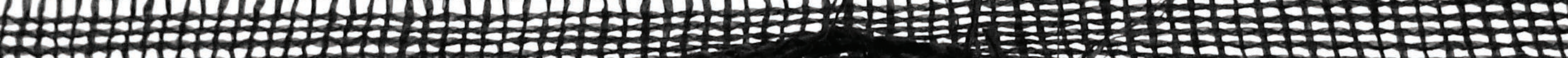

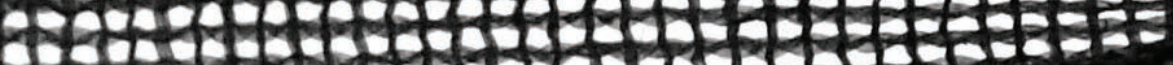

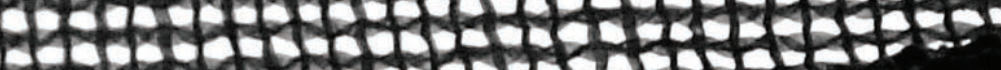
17+1

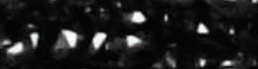
T3 Tht H.t. (1)

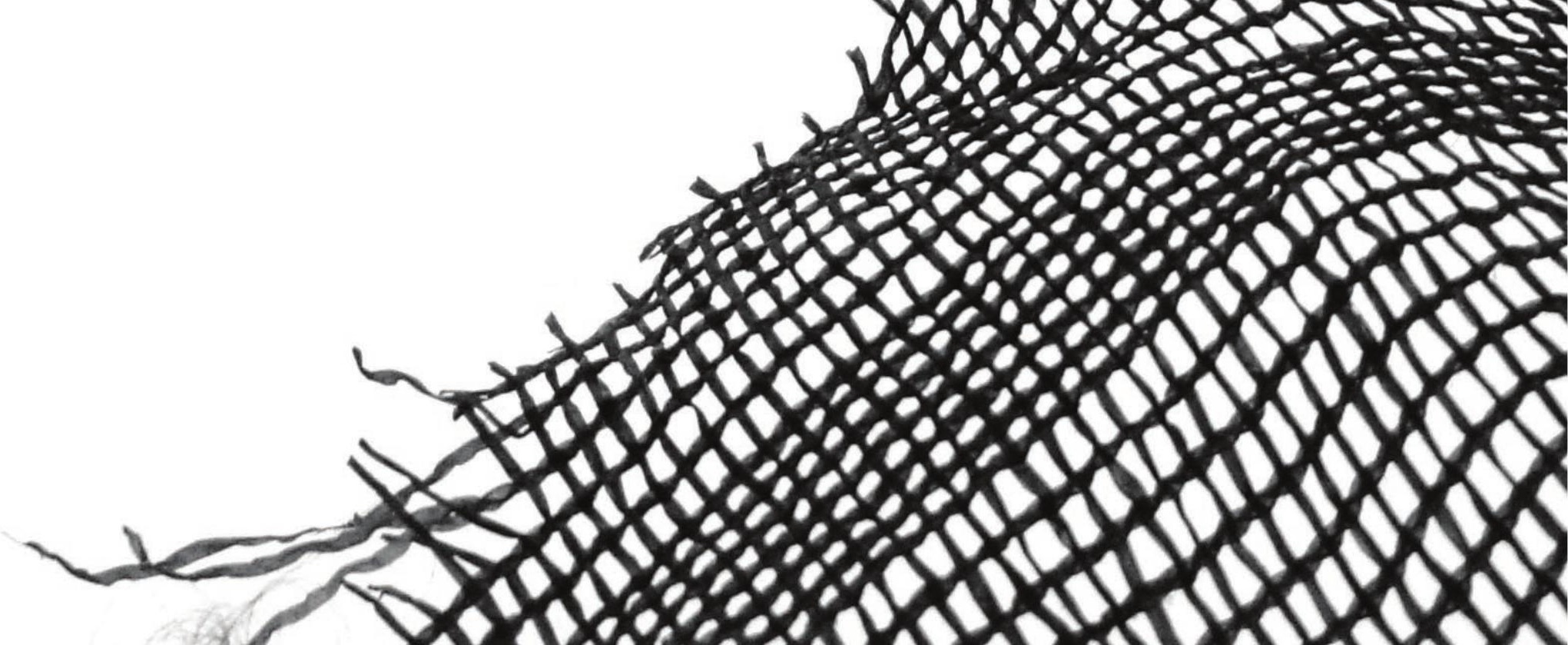




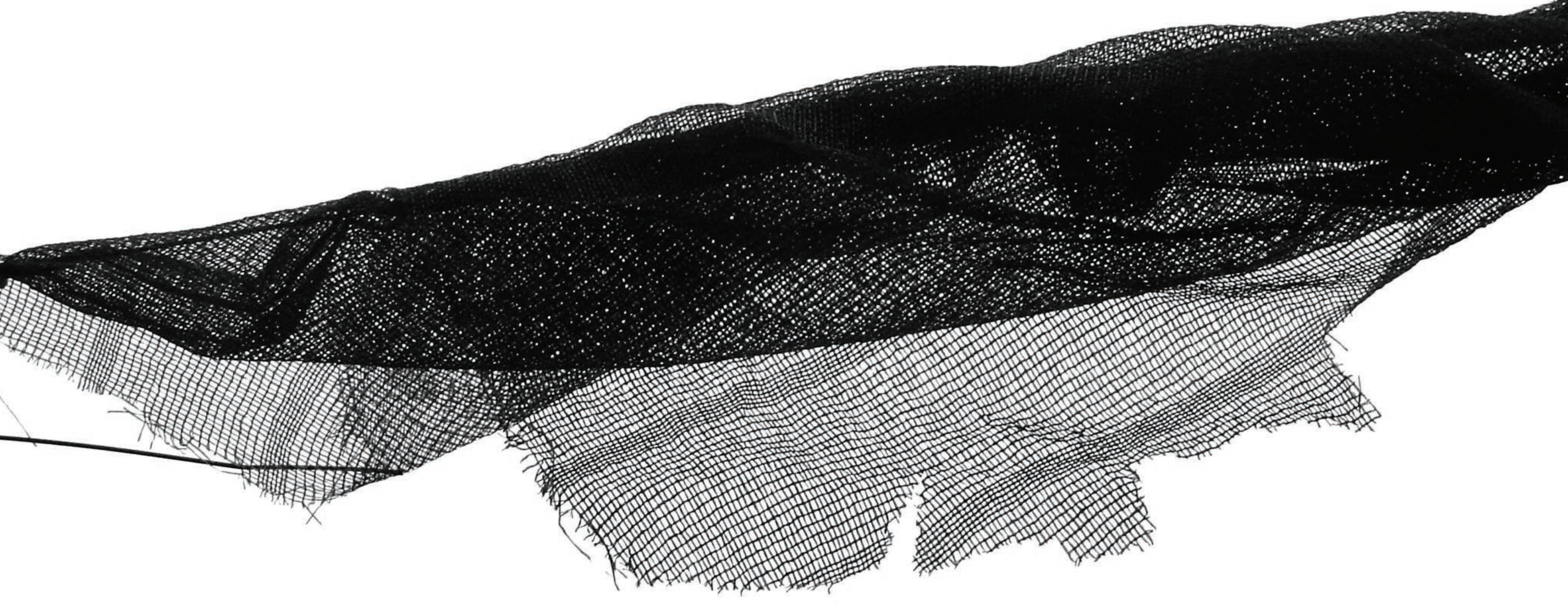



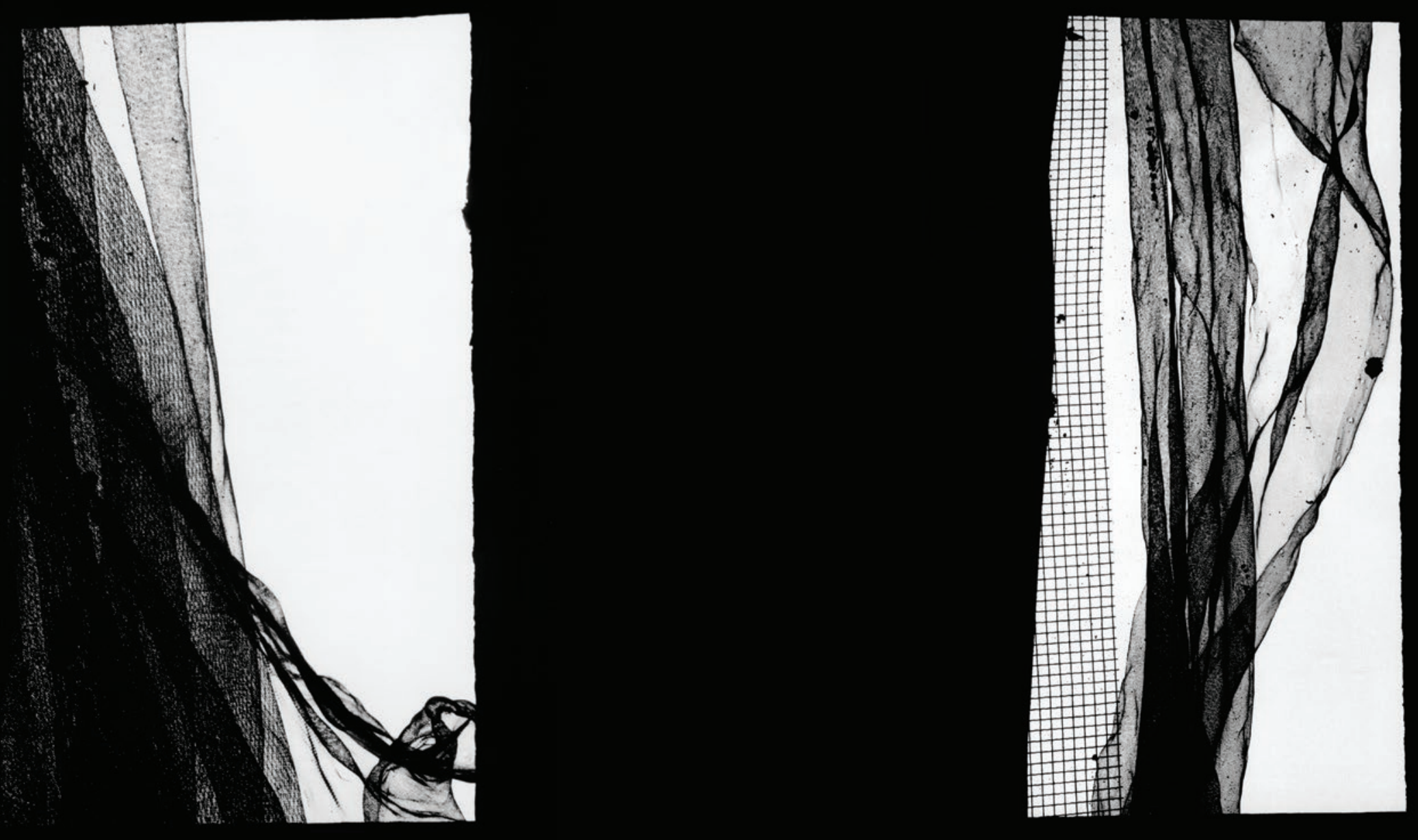

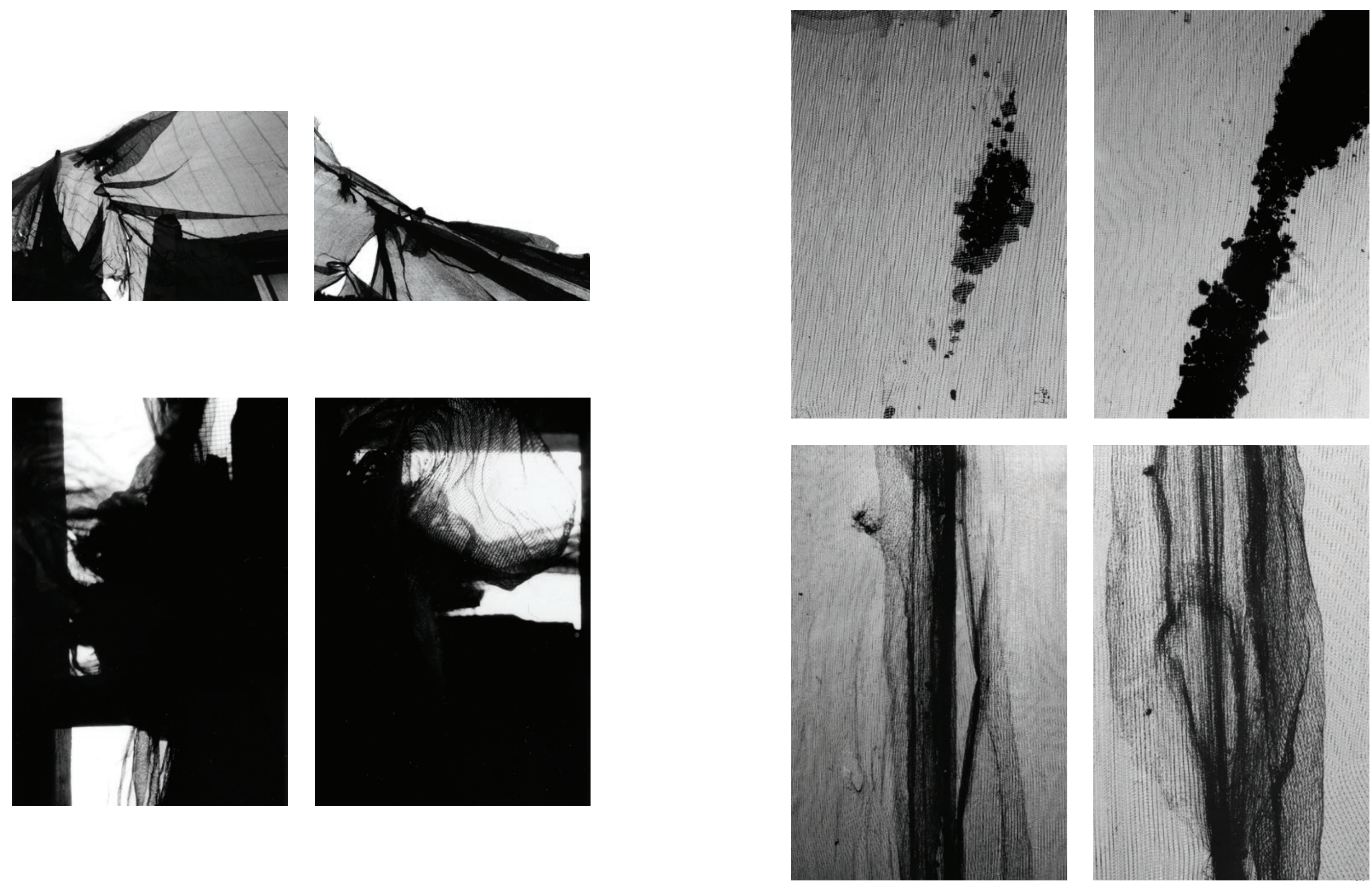

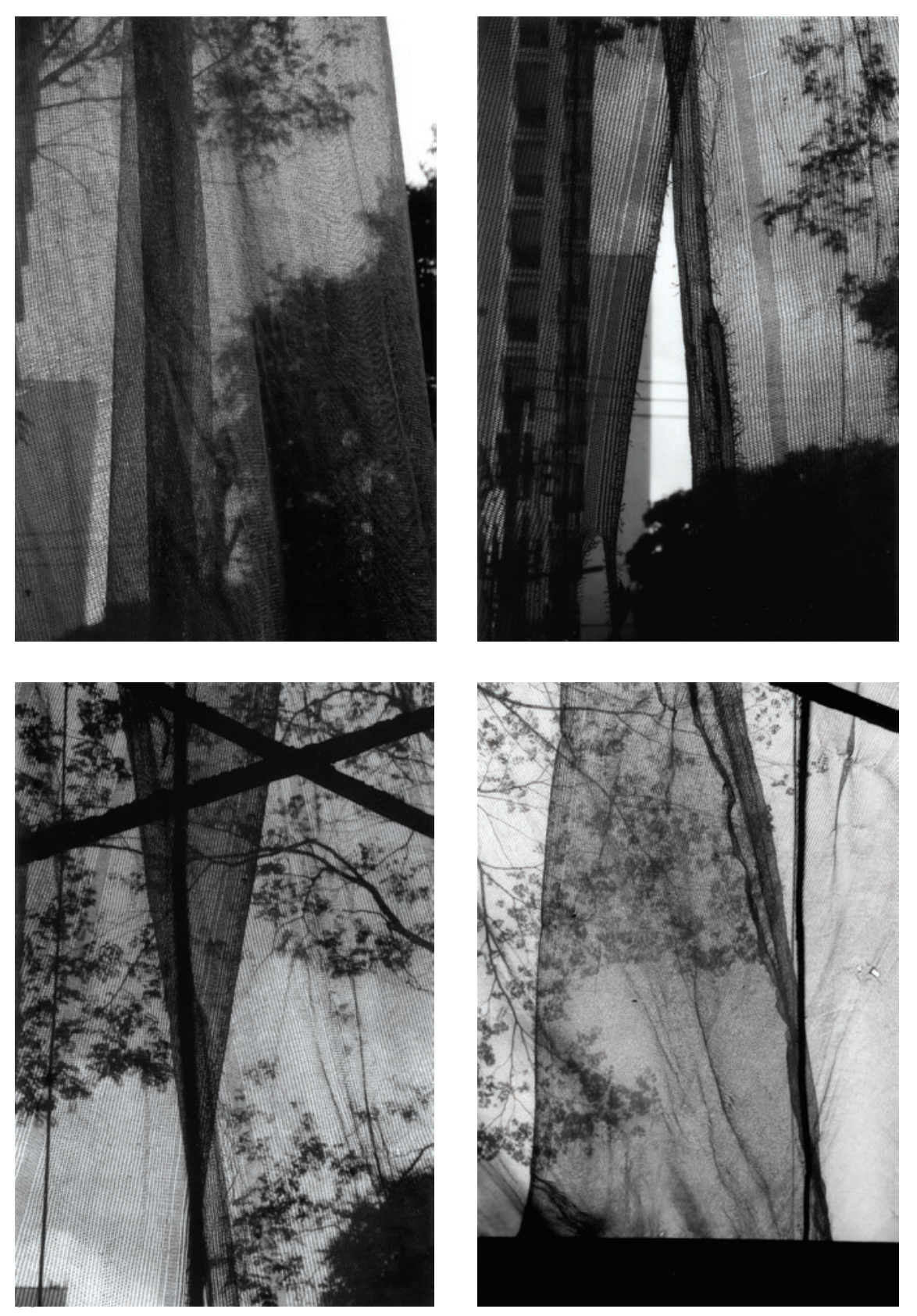
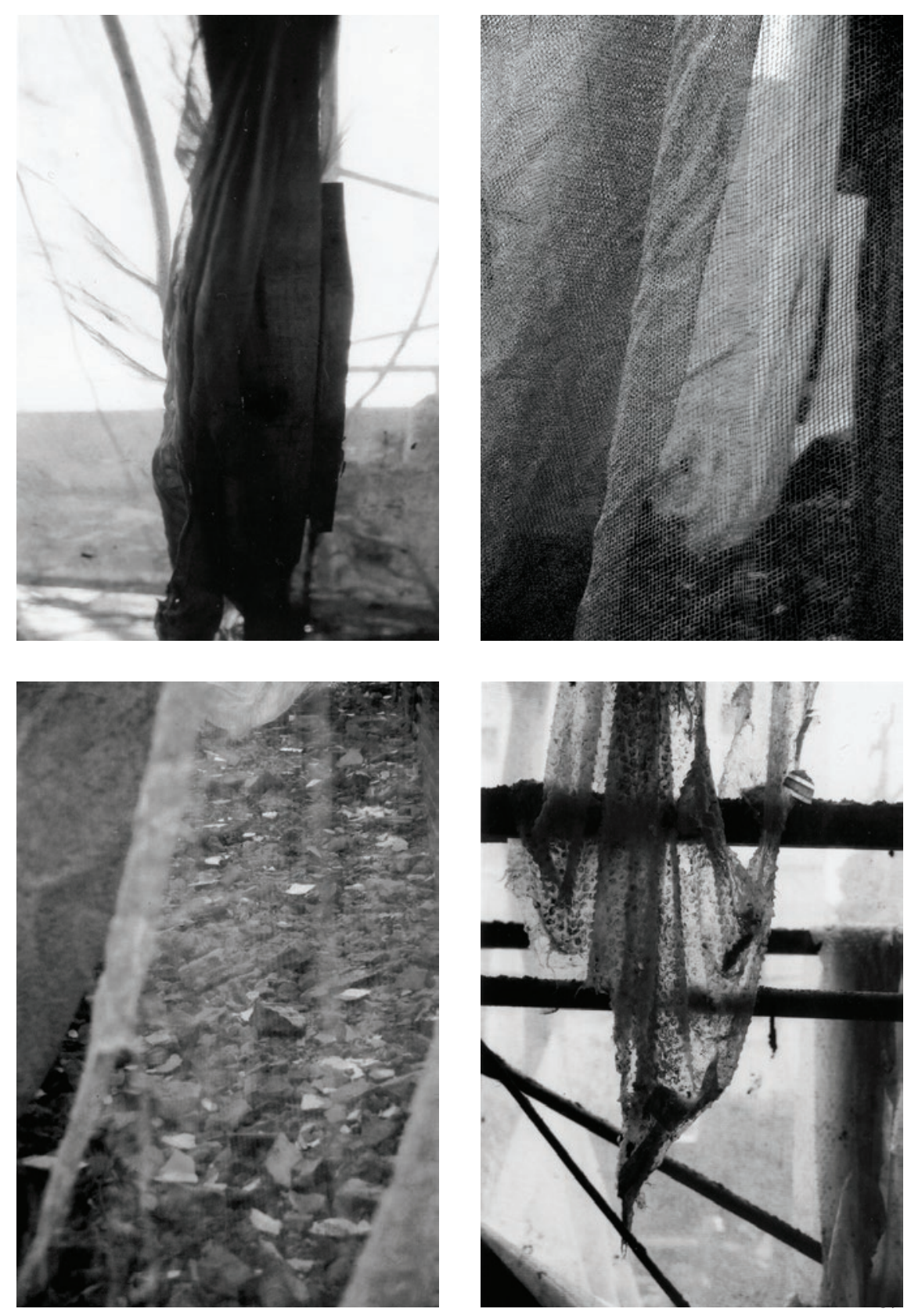
Propósitos

Ao estabelecer como objetivo da pesquisa a realização de experimentos visuais gráficos, em simultaneidade com o exercício de reflexão, era preciso ver trabalhos realizados anteriormente, para me rever. Comecei por reconsiderar ideias abandonadas, suspensas ou em processo, identificar questões latentes e possibilidades de desdobramento. Três conjuntos de trabalhos anteriores foram revisitados: Ventos, desenhos de observação de modelo-vivo e Vazios.

A série Ventos nasceu da observação de um pano de proteção para obras em edifícios, que cobriu as fachadas do prédio onde eu morava durante alguns dias. Da minha janela, vi e registrei, com a câmera fotográfica, o movimento do pano ao vento. Vistas de fora, as janelas dos edifícios enfileiram e empilham recortes de vidas privadas em um mosaico infinito de simultaneidades. Em São Paulo, nos habituamos ao jogo diário do isolamento e do convívio, que é por vezes mediado pela janela: "minha liberdade pequena e enquadrada me une à liberdade do mundo. Mas o que é uma janela senão o ar emoldurado por esquadrias?" (LISPECTOR, 1998a, p. 24).

A impossibilidade de avistar o horizonte confundia-se com falta de liberdade. Mas o pano que se materializou na minha janela era um objeto livre, ele voava conforme o vento e contra o céu. Inflava como um corpo de ar que respira lentamente e em silêncio. Pensei em leveza, flutuação. Pensei em tramas e urdiduras, camadas e veladuras, pontos de luz que vibram no negativo da trama, qualidade gráfica das linhas pretas emaranhadas, contrastes e meios-tons.

Naquele momento, já me interessava o caráter fluido da imagem digital, a possibilidade de produzir cópias em diversos formatos e diversos suportes. Passei a registrar também outras situações semelhantes encontradas pela cidade. Noto, também, nesta série, múltiplas reflexões sobre corpo, presença, vibração, instante, que persistem. 
Desenhos de observação

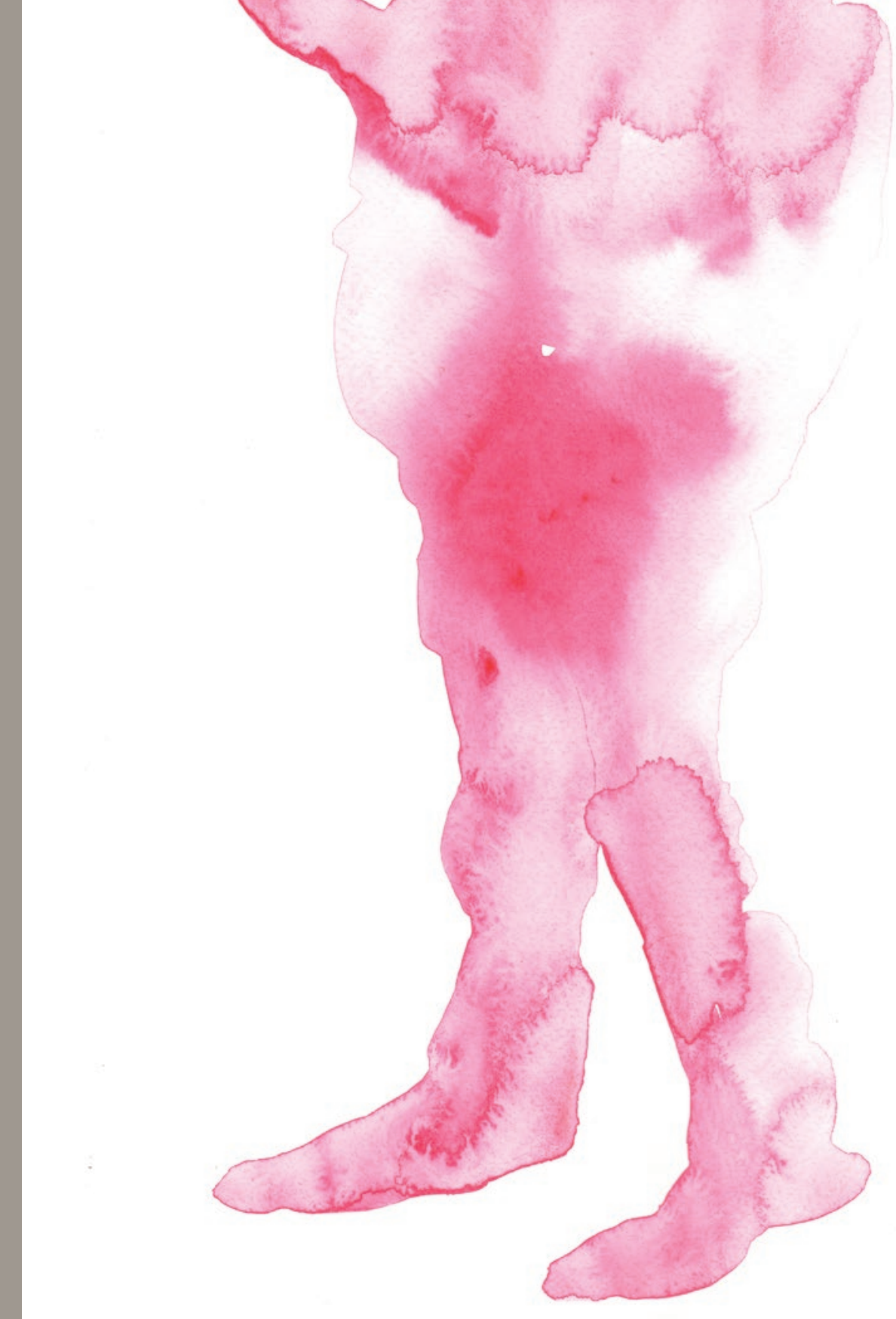




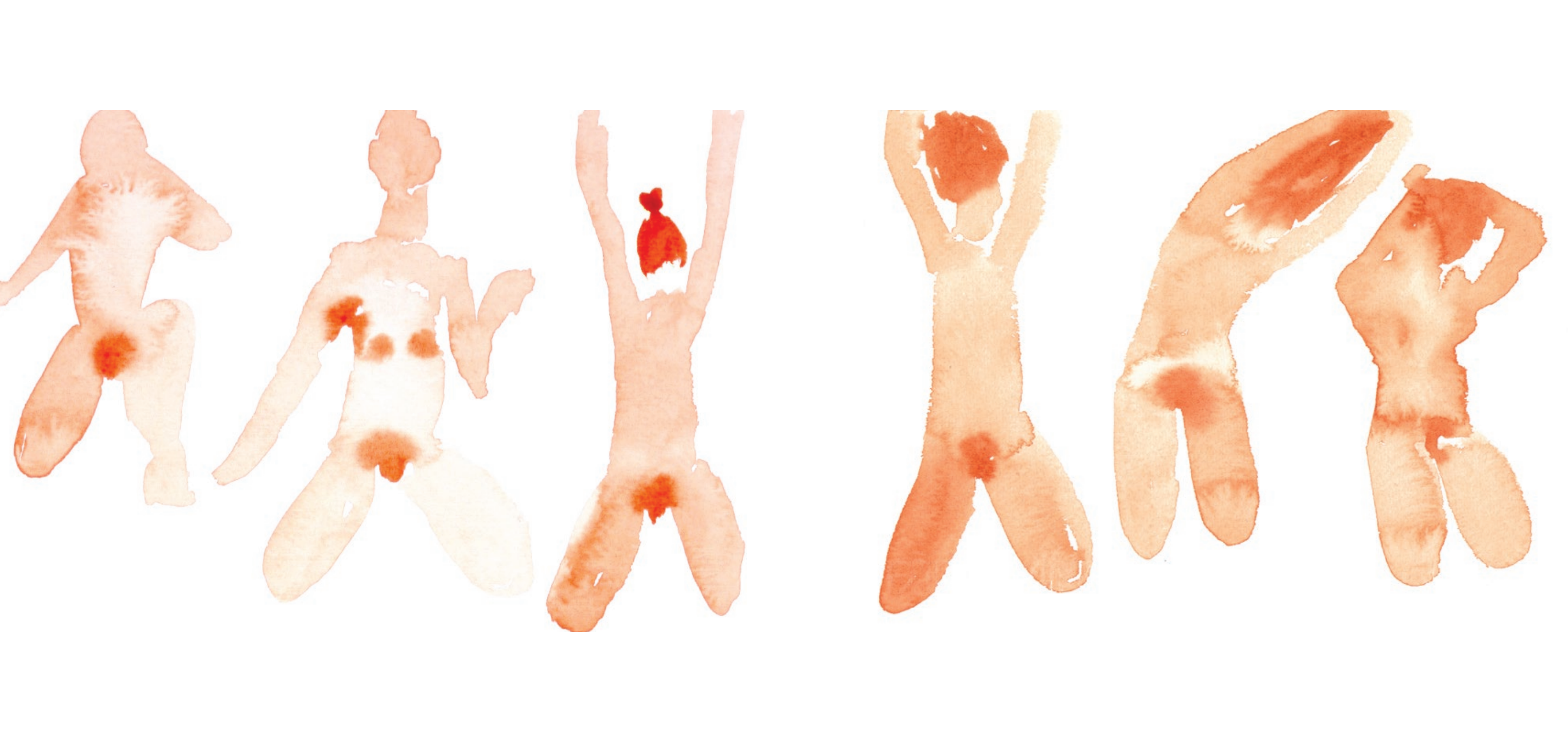




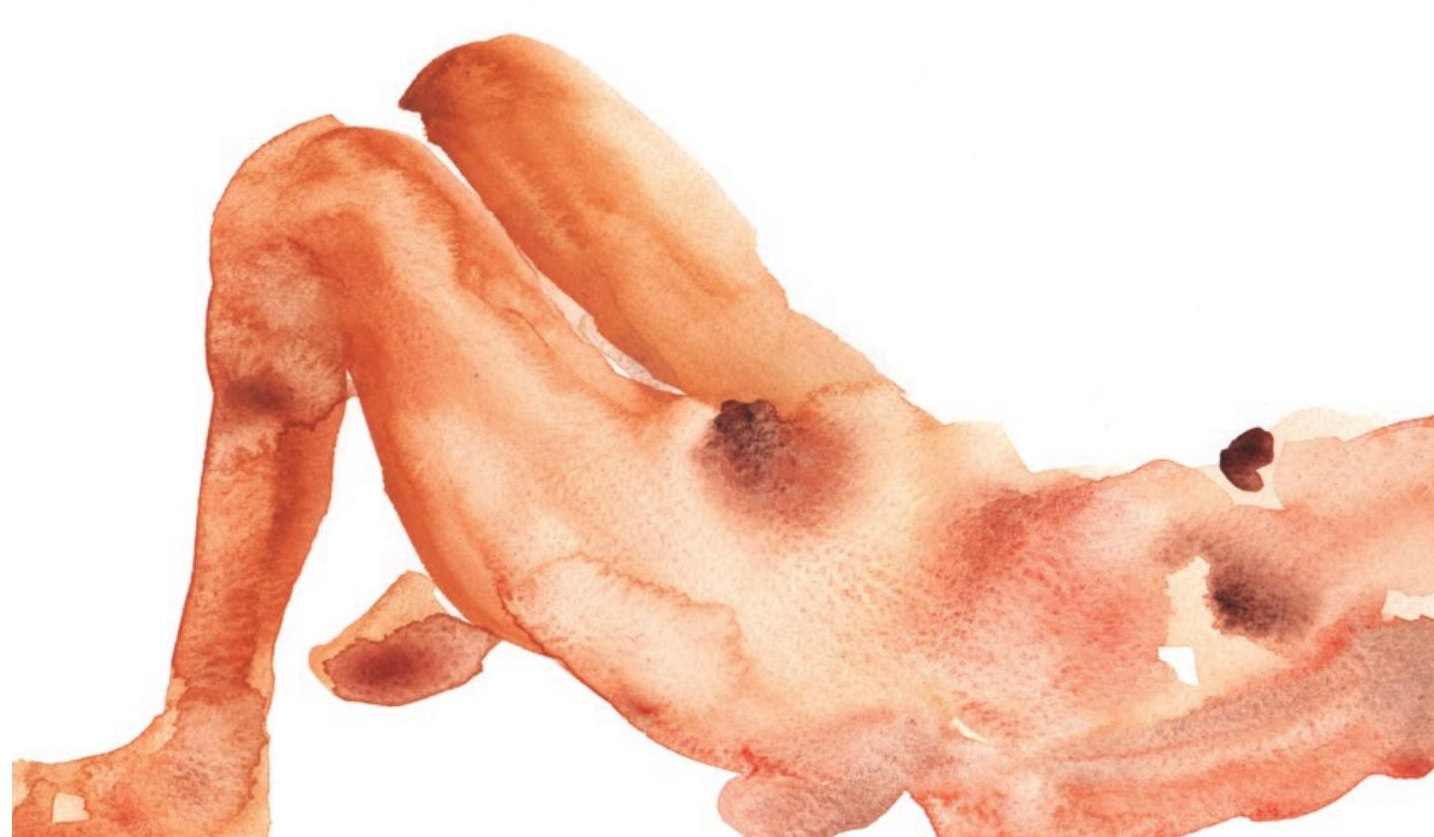




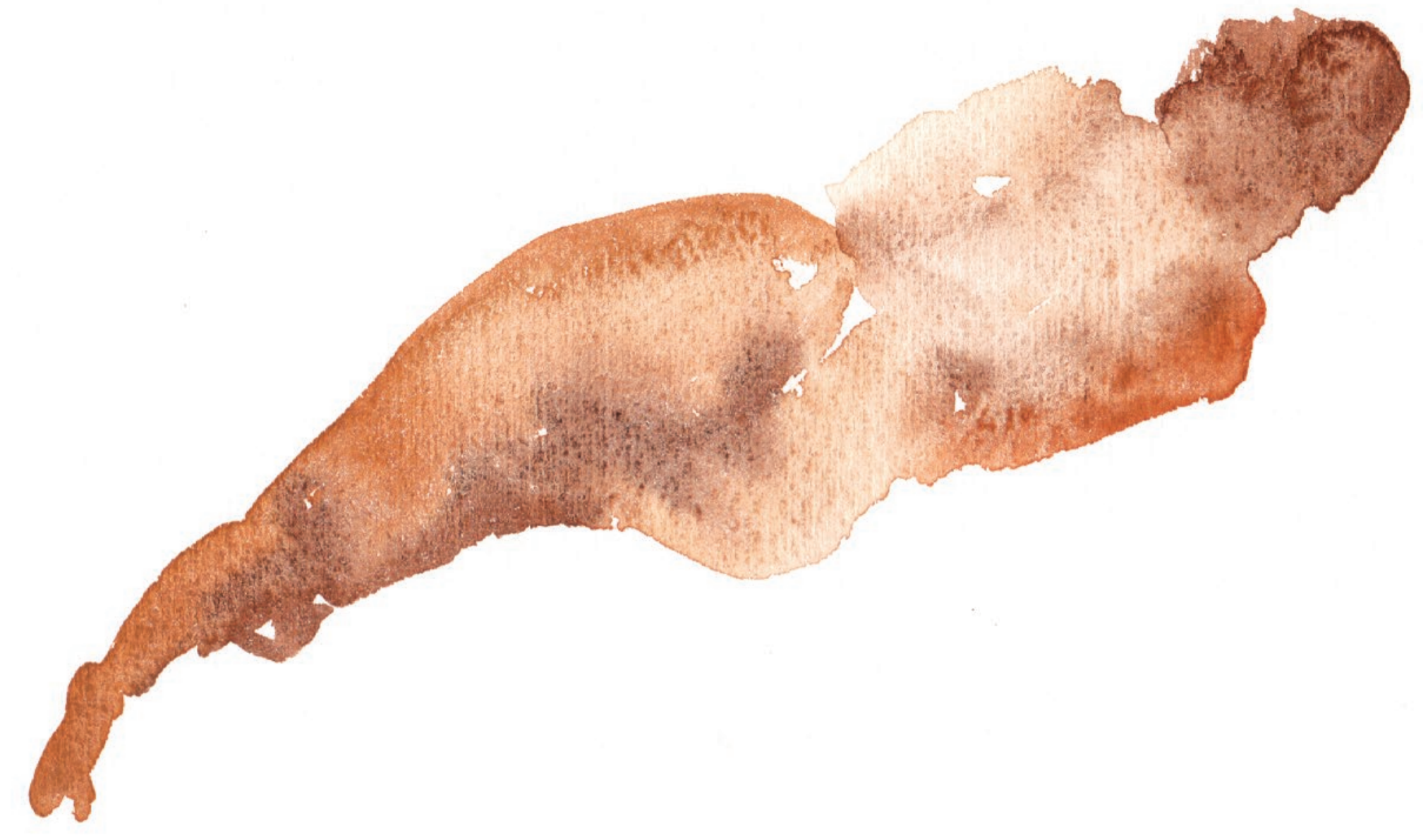




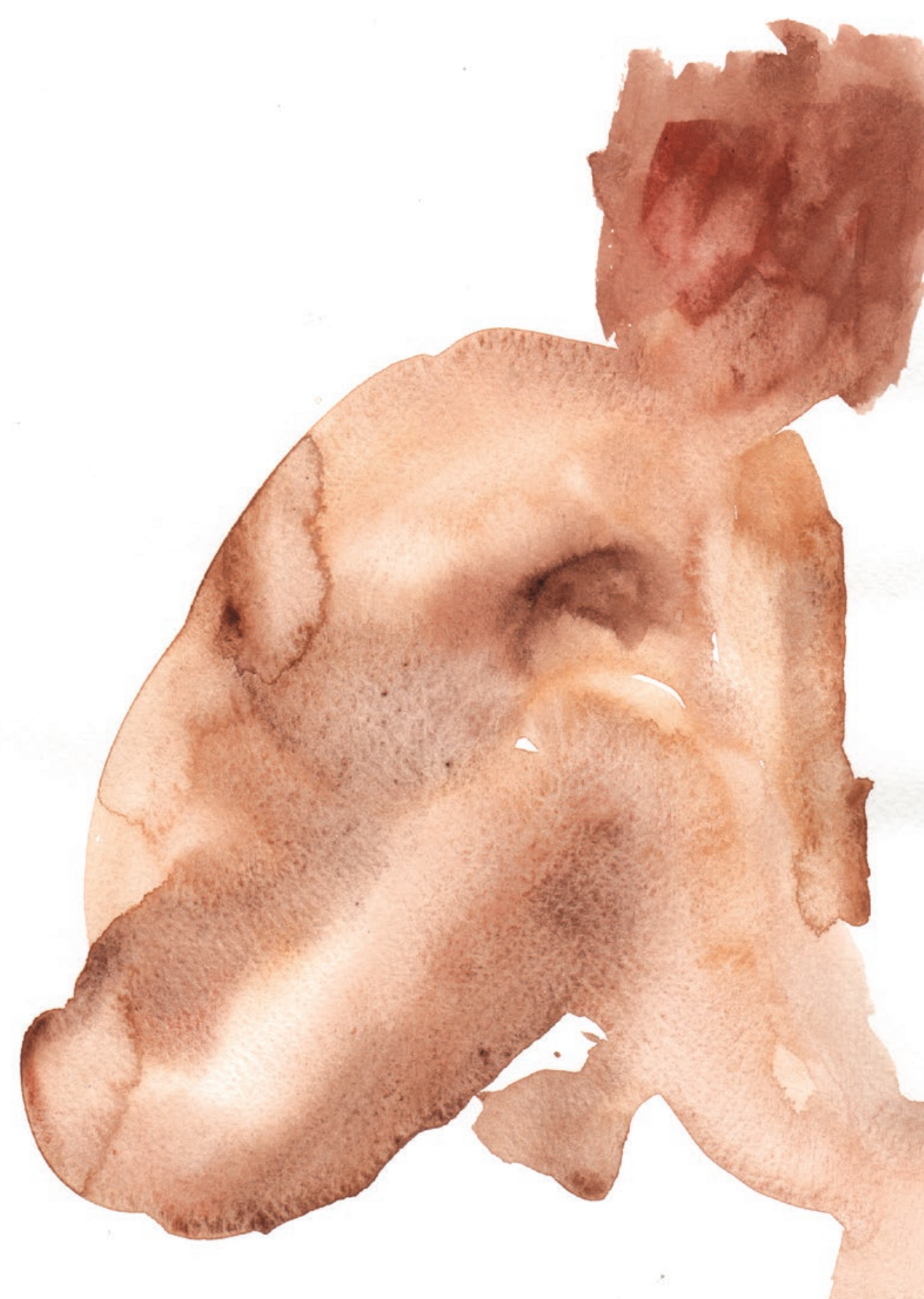




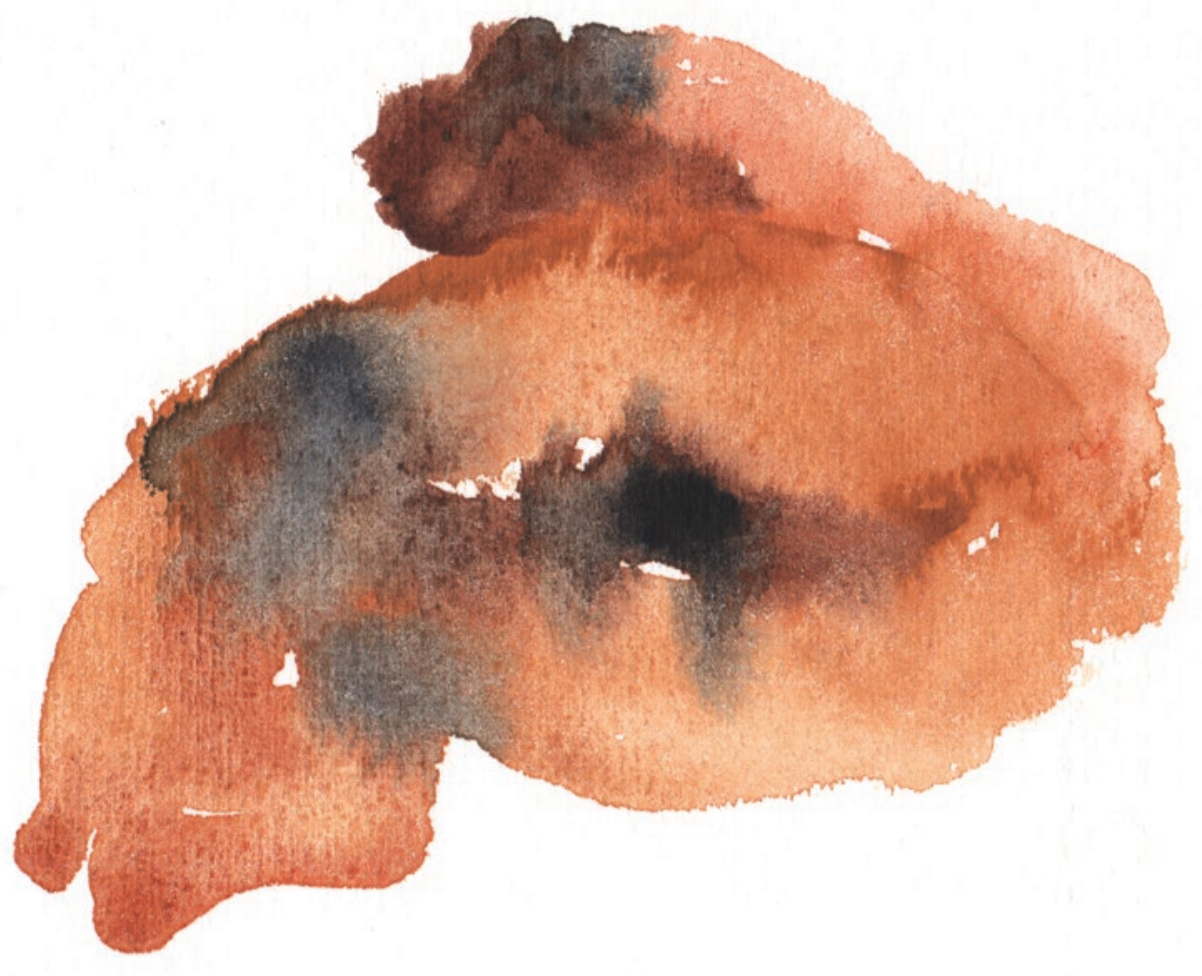



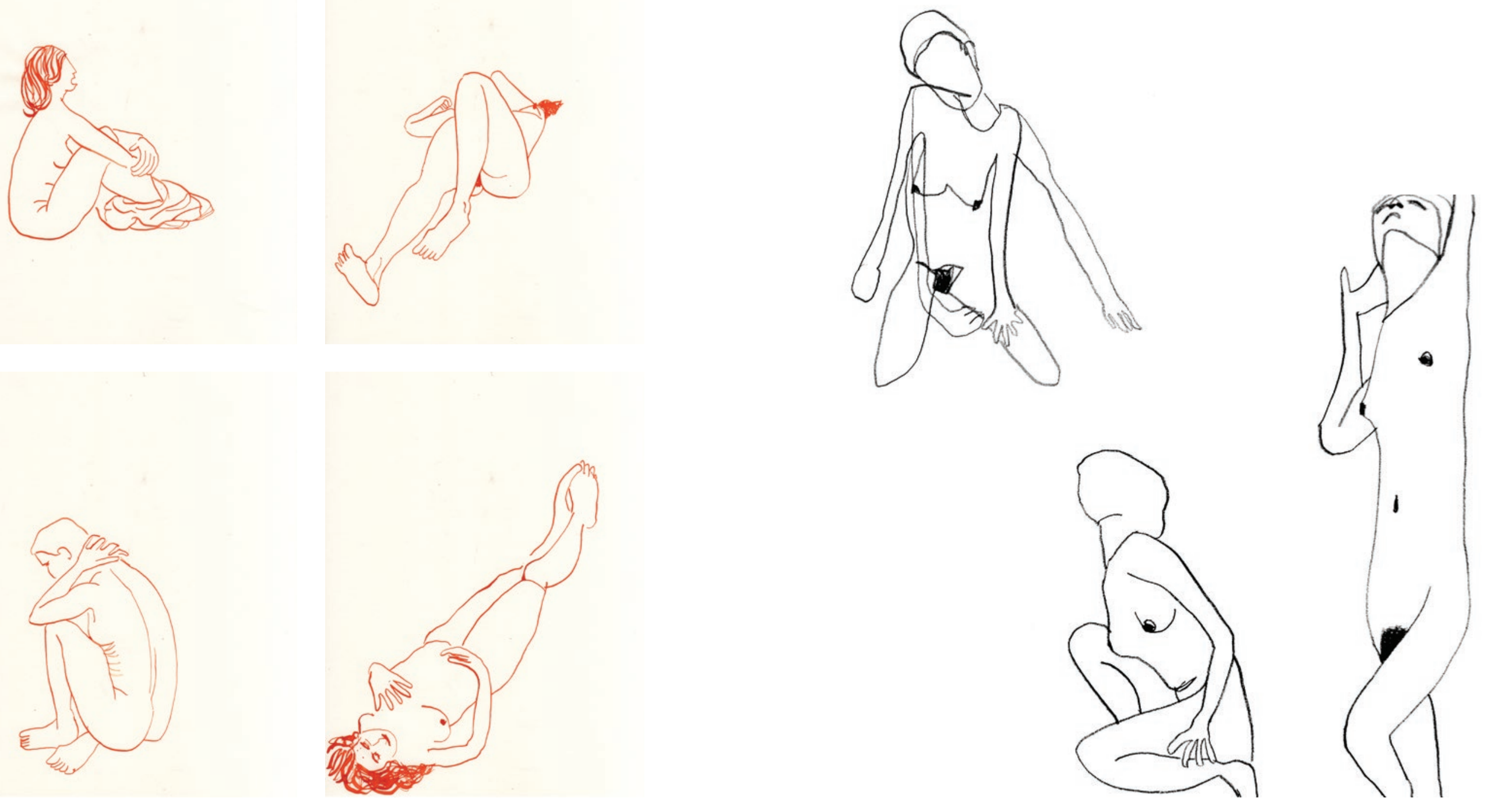


$$
\text { D) }
$$




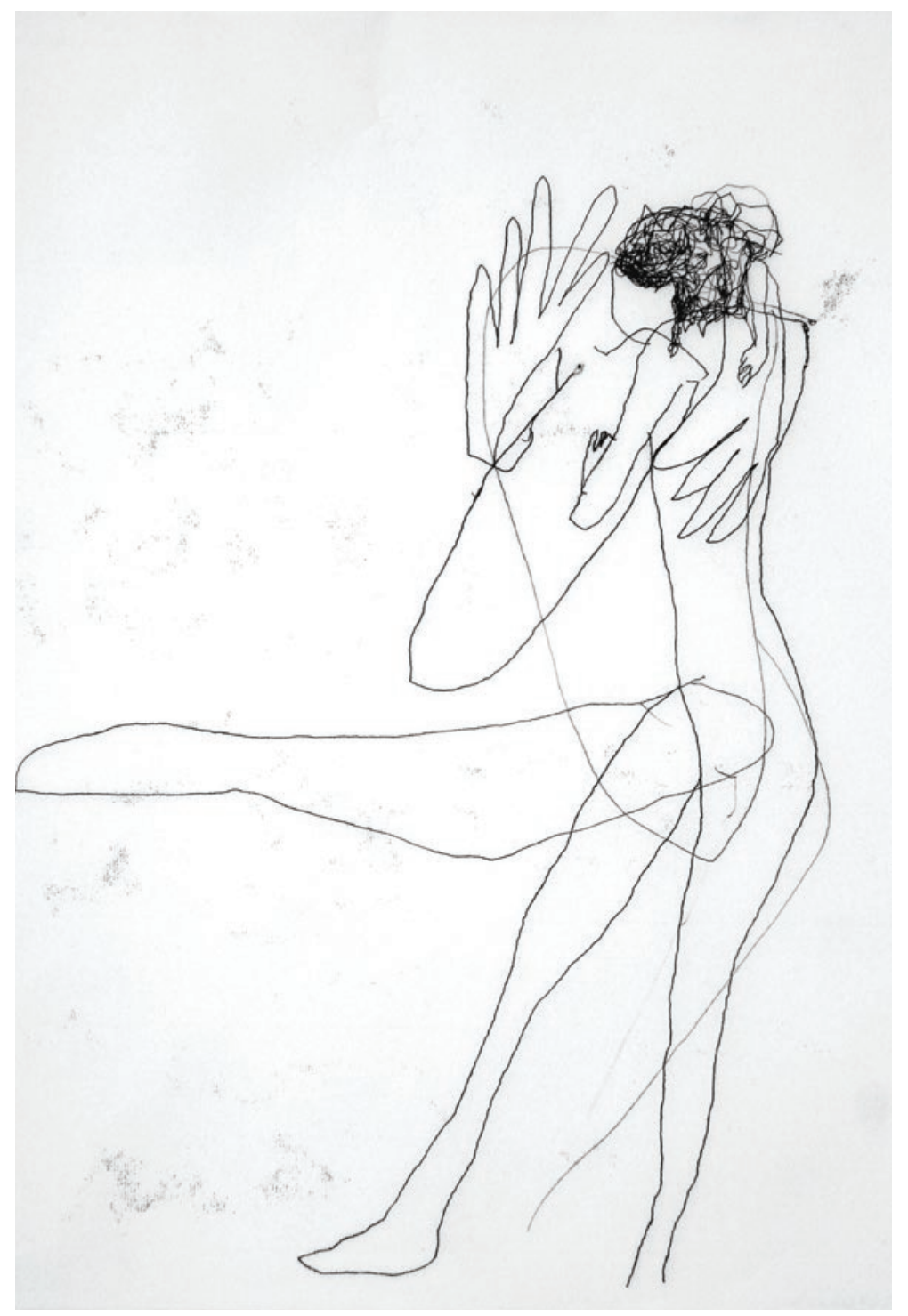

O que significa estar presente? Encontro essa mesma pergunta nos desenhos e aquarelas feitos a partir da observação de modelo-vivo. A experiência corporal é uma forma fundamental de consciência de si, por nos permitir traçar uma fronteira entre nós mesmos e o mundo (MARZANO, 2012). Quando desenho o corpo do outro, fico mais atenta ao meu próprio. Percorro com os olhos a linha-limite entre corpo e espaço. Observo a organização óssea que tudo estrutura: o que se vê por trás do opaco é o que se sabe que está lá. Comparo a substância do osso - que permanece quase igual do nascimento à morte, sofrendo uma transformação lenta ao sangue, que se renova a cada respiração. Observo o músculo que tensiona, estica, torce. Além de ser desenho, o traço é o registro do instante em que convivem o corpo que posa e o corpo que olha.

Tente entender o que pinto e o que escrevo agora. Vou explicar: na pintura como na escritura procuro ver estritamente no momento em que vejo - e não ver através da memória de ter visto num instante passado. $\mathrm{O}$ instante é esse. $\mathrm{O}$ instante é de uma iminência que me tira o fôlego. $\mathrm{O}$ instante é em si mesmo iminente. Ao mesmo tempo que eu o vivo, lanço-me na sua passagem para o outro instante. (LISPECTOR, 1998a, p. 69).

O desenho de observação com modelo-vivo, prática que vivenciei durante alguns anos, manteve-me alerta para pensar sobre a presença corporal e sobre o conceito de corpo na contemporaneidade. Que corpo padronizado é este? A quais testes é submetido? Até onde suporta e o que possibilita? Como se dá a percepção do mundo pela via corporal? 
O corpo é um objeto particular e ambíguo. Cada um de nós pode efetivamente contemplá-lo de fora e distanciar-se dele. É o caso do corpo do outro: um corpo entre outros que, no entanto, remete a uma presença diferente da dos outros objetos materiais; um corpo que dá acesso a uma imagem, a uma aparência e que, ao mesmo tempo, remete ao próprio ser da pessoa que está diante de nós. Mas é também nosso próprio corpo: um corpo imagem que podemos contemplar num espelho; um corpo fragmentado quando olhamos nossas mãos ou nossos pés. [...]

Nosso corpo é uma das evidências de nossa existência: é nele e com ele que nascemos, vivemos e morremos; é nele e com ele que construímos nossas relações com o outro. Mas nós somos ou temos nosso corpo? (MARZANO, 2012, p. 8).

O sentido de corpo desdobra-se em uma multiplicidade de relações: corpo como substância física dos homens e animais, corpo como propriedade material dos objetos, corpo social e político, corpo nômade, corpo virtual, corpo morto, corpo d'água ${ }^{3}$... e corpo de provas ${ }^{4}$.

${ }^{3}$ Corpo d'água ou corpo hídrico é denominação genérica para qualquer manancial hídrico; curso d'água, trecho de rio, reservatório artificial ou natural, lago, lagoa ou aquífero subterrâneo. Superintendência de Recursos Hídricos Secretaria de Estado do Meio Ambiente e dos Recursos Hídricos do Governo de Sergipe. Disponível em: $<$ http://www.semarh.se.gov.br/srh/modules/tinydo/index.php?id=8>. Acesso em 08/05/2013.

4 "No campo da engenharia civil, denomina-se 'corpo de prova' uma amostra de forma e dimensões padronizadas, preparada para ser submetida a ensaios com o fim de se verificarem determinadas características do material que a constitui" (FERREIRA, 1975)
Alberto Giacometti

Experiência visceral do processo de criação, busca incessante, construção e

destruição, fracasso e

recomeço. A impossibilidade Louise Bourgeois da representação. A arte como o único gesto de liberdade possível.

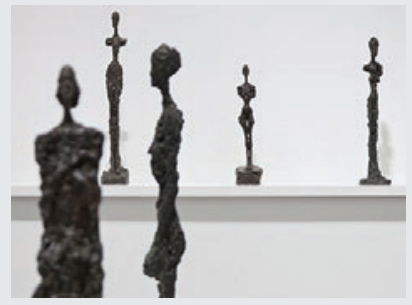

Exposição de Alberto Giacometti Pinacoteca de São Paulo, 2012 Corpo, vísceras, desejo, memória, emoção, pulsão, resiliência.

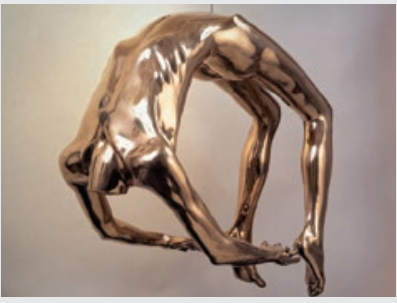

Louise Bourgeois

Antony Gormley

Adoção da própria existência e do próprio corpo como molde de pensamento e ação. Tensão entre corpo e lugar.

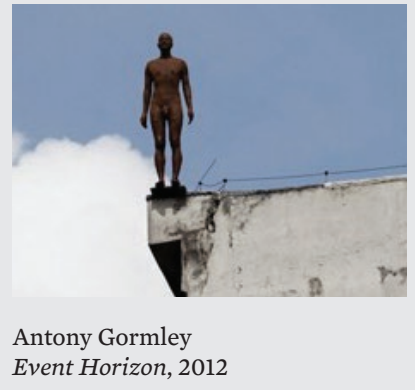

Filme Cosmópolis A condição do corpo na sociedade contemporânea ocidental: virtual, solitário, doente e mecanizado.

Filme A caverna dos sonhos esquecidos A história da imaginação e da representação simbólica. Registro da presença e passagem do tempo.

Filme Pina

A libertação do corpo que dança. Desejos, desenhos e desígnios corporais O espaço cênico.

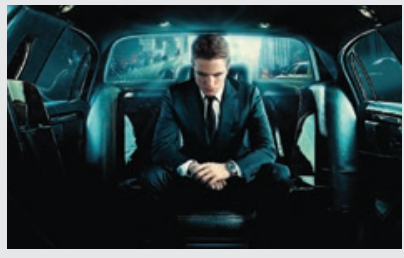

Cosmópolis, 2012 David Cronenber

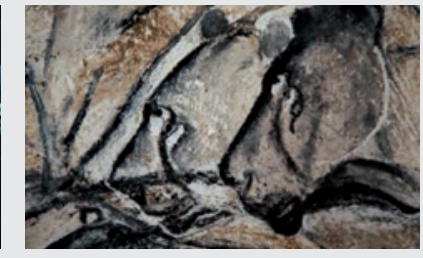

A caverna dos sonhos esquecidos, 2010 Werner Herzog

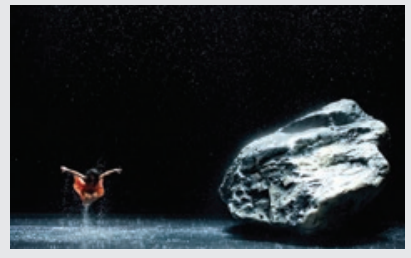

Pina, 2011 Wim Wenders 
Varios

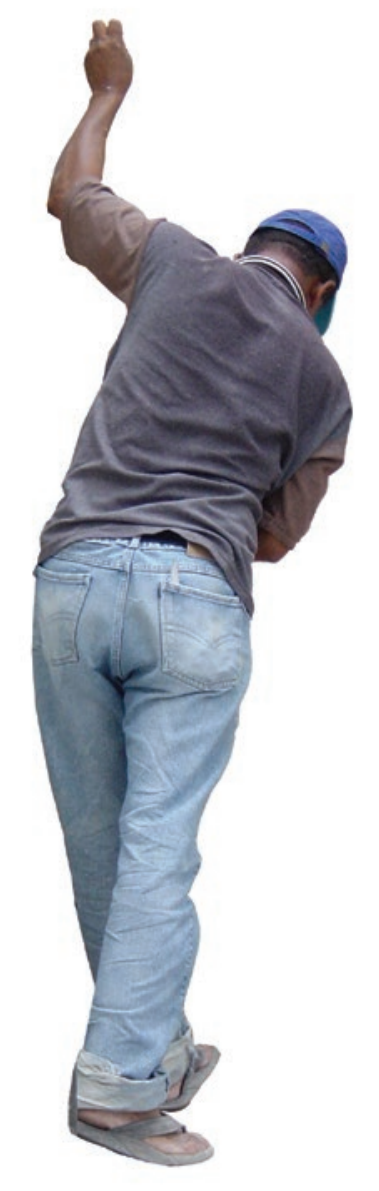



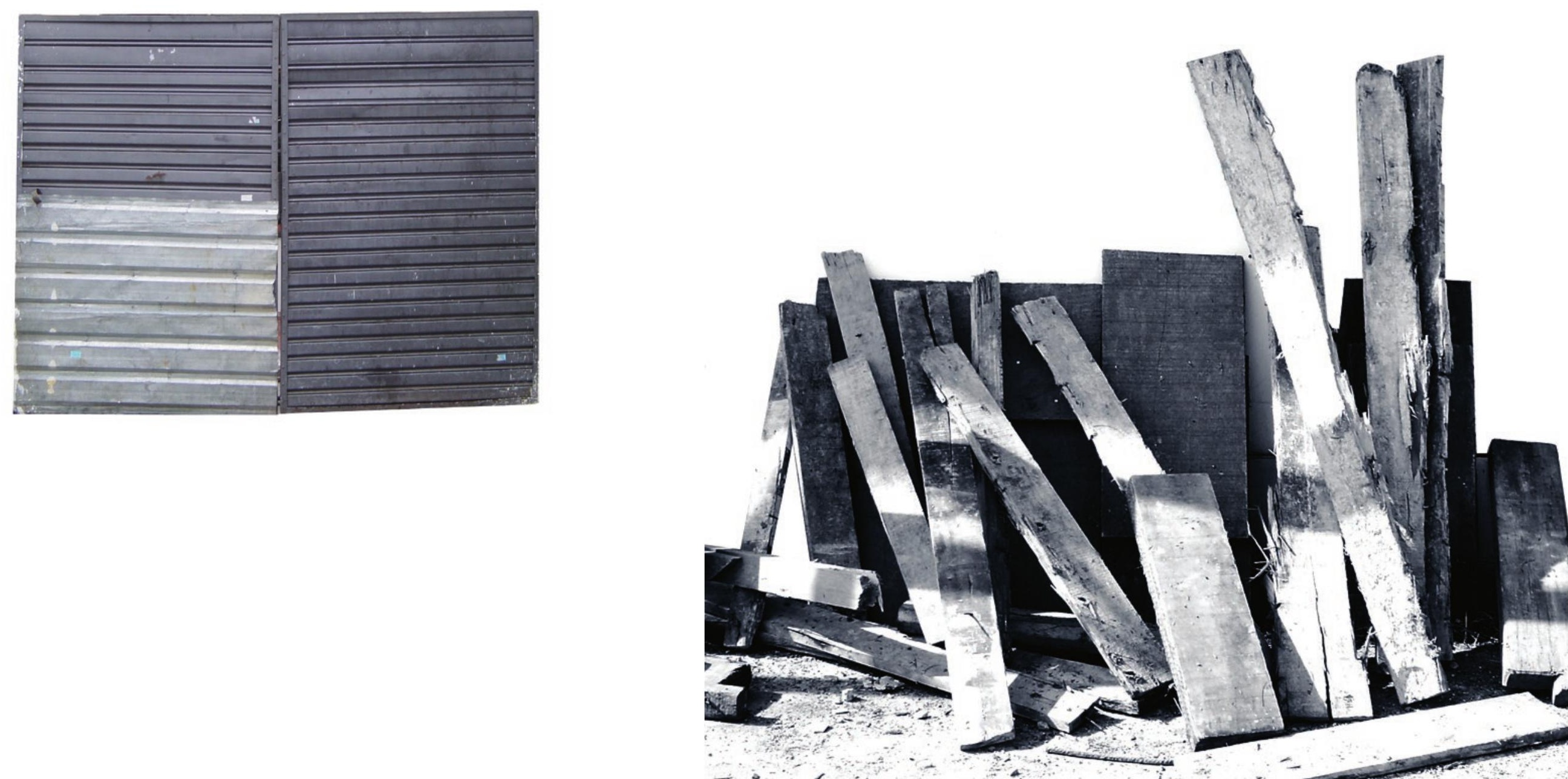


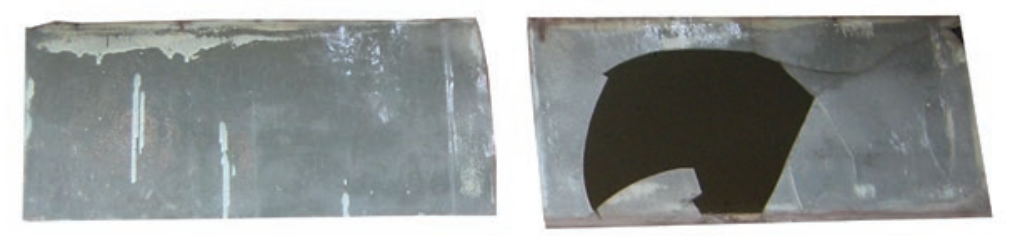



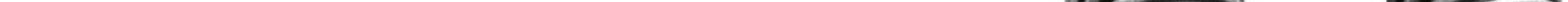


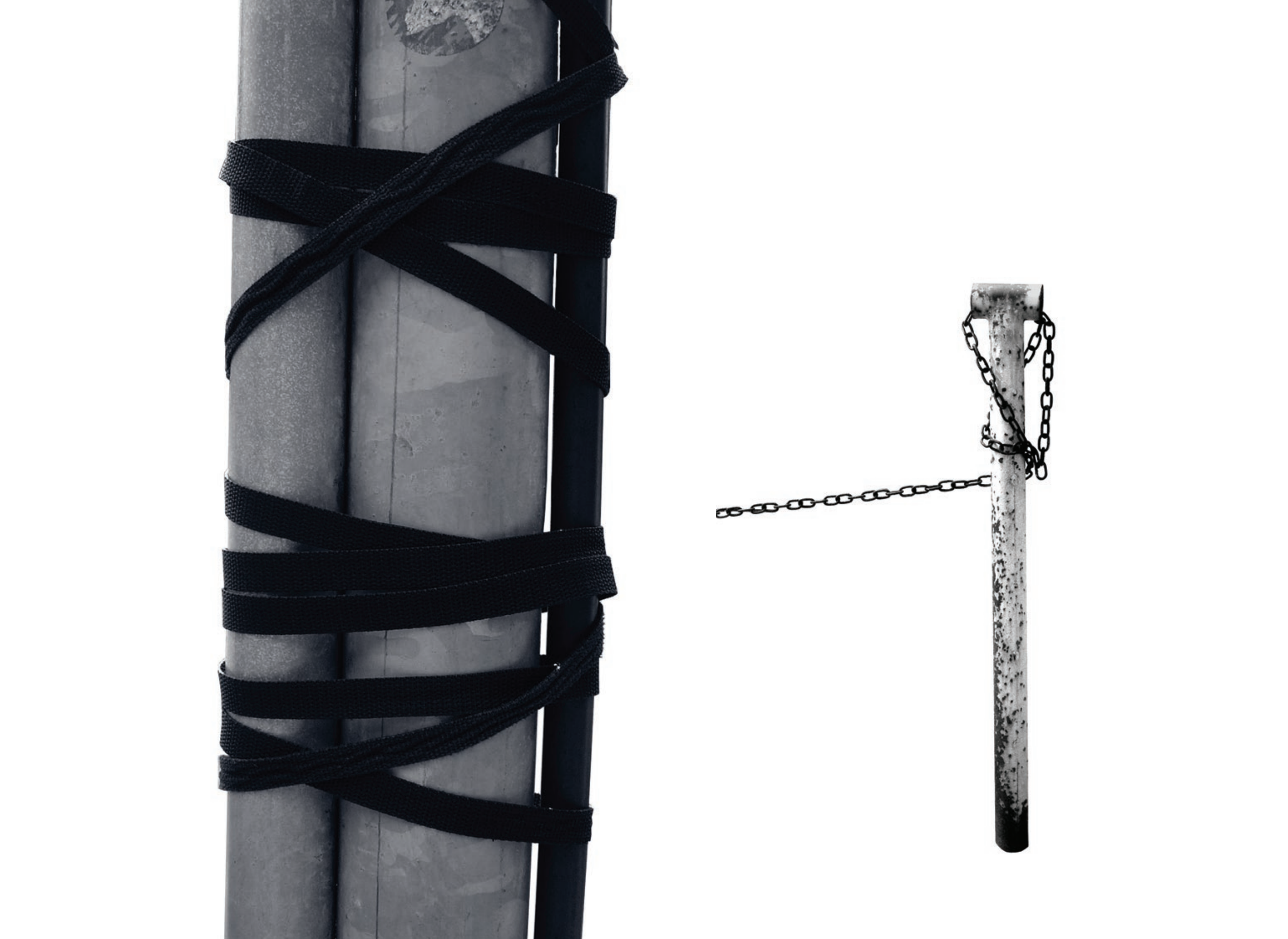





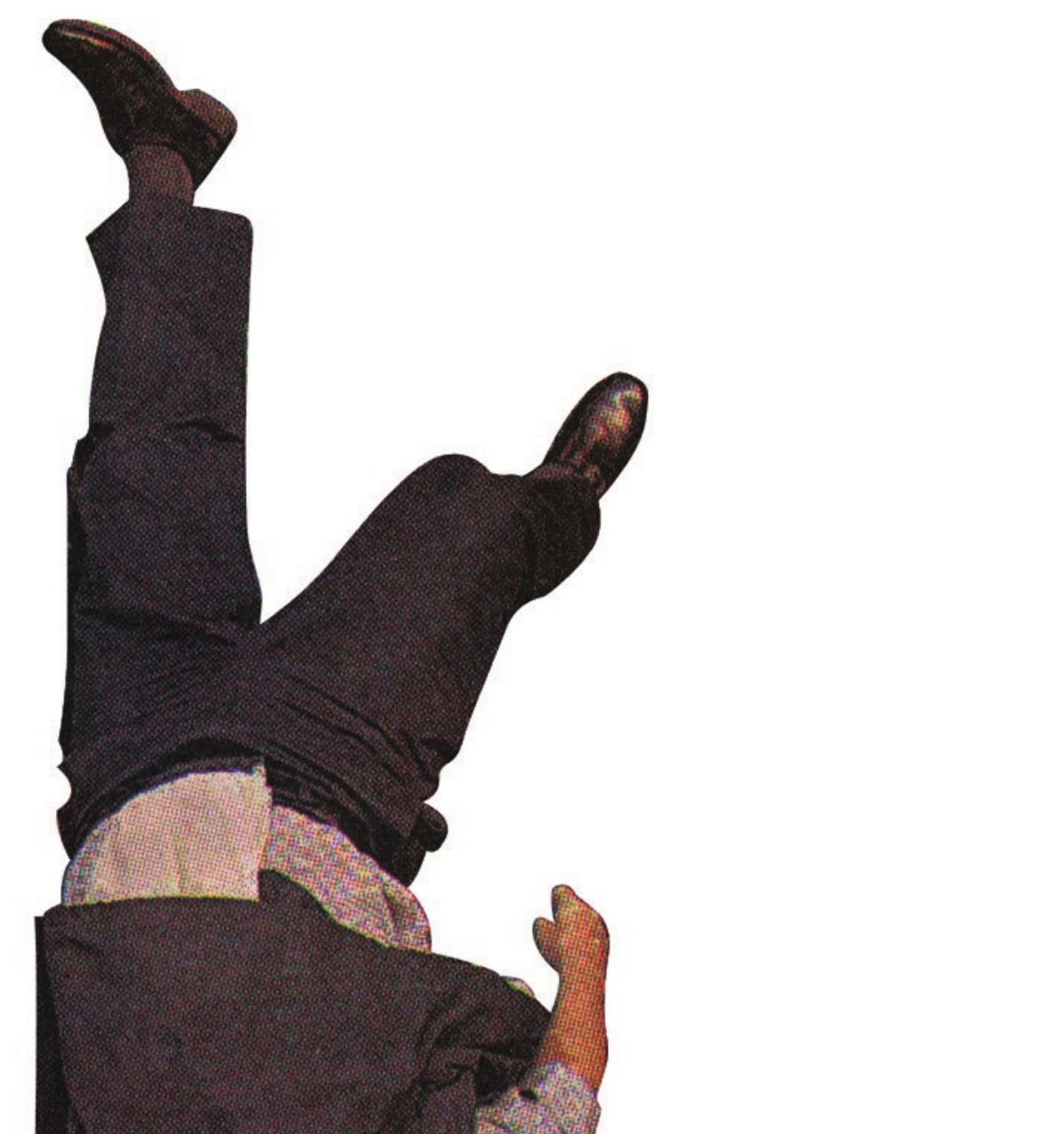




$$
\text { AII }
$$




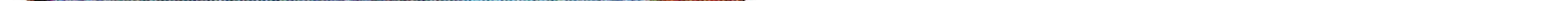


Em Vazios, recortei imagens de objetos e pessoas - encontrados em fotografias que produzi durante passeios pela cidade ou em jornais impressos - e as posicionei sobre um campo branco. Considero que os objetos que elegi fotografar e, em seguida, recortar sua imagem, são corpos também: alusão a corpos estranhos à cidade, em pé, deitados, pendurados... perseverando em sua existência inanimada. As imagens de pessoas, por sua vez, ao serem recortadas - e, portanto, excluídas da cena fotográfica que contextualiza a pose -, parecem mostrar melhor seus desígnios corporais. No silêncio da folha branca, o corpo dança uma dança surda, em um espaço que é lugar nenhum.

A imagem do corpo no vazio, excluído da paisagem, é a expressão de um certo deslugar, uma desterritorialização, um desencontro solitário com o mundo exterior. Quem é cada um, afinal, quando revestido apenas pelo corpo, adjetivado por gestos particulares, mas despojado de contexto geográfico e histórico?

O branco que envolve a figura é um vácuo repleto de possibilidades. Como na pintura chinesa, em que o espaço vazio não é vago ou inexistente, mas dinâmico. É uma presença permeada por vibrações que conectam o mundo visível ao invisível (CHENG, 1994).
Na perspectiva chinesa, montanha e água ficariam em uma relação de oposição rígida e, portanto, estática, se não houvesse o vazio entre elas. Cada uma iria se opor à outra e, através dessa oposição, seria confirmado o seu estado definitivo. Tendo o vazio como intermediário, o pintor cria a impressão de que a montanha poderia praticamente entrar no vazio e derreter-se nas ondas, e que, inversamente, a água, por meio do vazio, poderia elevar-se à montanha. Como resultado, montanha e água já não são percebidas como elementos divididos, opostos e estáticos, mas sim como expressão de uma realidade dinâmica. Com o rompimento da perspectiva pelo vazio dentro do campo pictórico, notamos mais uma vez essa relação de devires recíprocos entre os seres humanos e a natureza dentro da imagem, por um lado, e entre o espectador e a imagem como um todo, por outro. (CHENG, 1994, p. 37-38, tradução minha).

[...] Longe de ser uma espécie de terra de ninguém, que indicaria neutralização ou harmonia, o vazio torna possível o processo de interiorização e transformação através do qual cada coisa realiza-se em sua identidade e alteridade e, ao fazê-lo, alcança a totalidade. (CHENG, 1994, p. 38, tradução minha). 


\section{Colecionar o mundo}

Revisitei projetos anteriores ao tempo de execução desta tese e identifiquei ideias a serem retomadas. Ainda assim, não sabia por onde reconquistar a fluência do processo criativo. Na elaboração de um projeto artístico, cuja questão germina a partir de valores e intenções em constante maturação, nem sempre se sabe, de início, o que se pretende criar.

Não há, portanto, uma teoria fechada e pronta anterior ao fazer. A ação da mão do artista vai revelando esse projeto em construção. As tendências poéticas vão se definindo ao longo do percurso: são leis em estado de construção e transformação. Trata-se de um conjunto de princípios que colocam uma obra em criação específica e a obra de um artista como um todo em constante avaliação e julgamento. (SALLES, 2004, p. 40)

No início do processo de construção da tese, estabeleci uma rotina: no começo de cada dia, selecionava e guardava notícias e fotografias de notícias encontradas na internet. Fui coletando o que me interessava - tanto em termos do assunto informado pela imagem como do estímulo visual em si -, sem outros critérios preestabelecidos $^{5}$. Eu sabia, no entanto, que minha intenção era olhar para fora. Tenho uma fome de mundo: fatos, histórias, pessoas, lugares longe e perto.

${ }^{5} \mathrm{~A}$ experiência de coletar fotografias de notícias encaixa-se na categoria da primeiridade ou abdução, descrita por Peirce: "Peirce preocupou-se em estudar as categorias da experiência e, para isso, criou uma classificação especial de caráter numérico que subdivide as experiências em três classes distintas. Experiência de primeiridade é aquela que caracteriza uma qualidade única e intransferível;
Experiência feita do tecido de nossos atos diários, a outridade é antes de mais nada a percepção de que somos outros sem deixar de ser o que somos e que, sem deixar de estar onde estamos, nosso verdadeiro ser está em outra parte. Somos outra parte. Em outra parte quer dizer: aqui, agora mesmo enquanto faço isto ou aquilo. $\mathrm{E}$ também: estou só e estou contigo, em um não sei onde que é sempre aqui. Contigo e aqui: quem és tu, quem sou eu, onde estamos quando estamos aqui? (PAZ, 2005, p. 107)

Colhi, nos jornais, uma série de acontecimentos simultâneos e sucessivos, como:

foca albina - mulher morta encontrada dentro de uma mala - homem toma chuva em beirute - lixo à deriva no espaço - penitentes na semana santa - touros se banham no paquistão - lama tóxica na hungria - caranguejos morrem na praia após fugir do mangue - lavanderia na índia - gato com equipamentos presos ao corpo invade presídio - desfile de moda em pequim - um vendedor de pão no afeganistão - policial que desarma uma bomba - fábrica de tijolos em chandigarh - lixo à deriva nos oceanos - meninos rebeldes em atenas - um goleiro de futebol - livros queimados no cairo - tsunami no japão - trens lotados em bangladesh - coreanos do norte - ginastas suíças - homem que nada em lago congelado - mulheres que vestem burca - indianos trabalham em uma mina de carvão - um buraco no asfalto em são paulo - torcida em um estádio de futebol - um vulcão no méxico - alagamento na tailândia

experiência de secundidade é aquela decorrente de uma reação a um choque, a um conflito entre ações ou hábitos, ocorrendo aqui e agora e apenas uma vez; se repetida e contínua, passa a ser reação com força de lei que ocorre no domínio da terceiridade" (FERRARA, 1999, p. 159). 

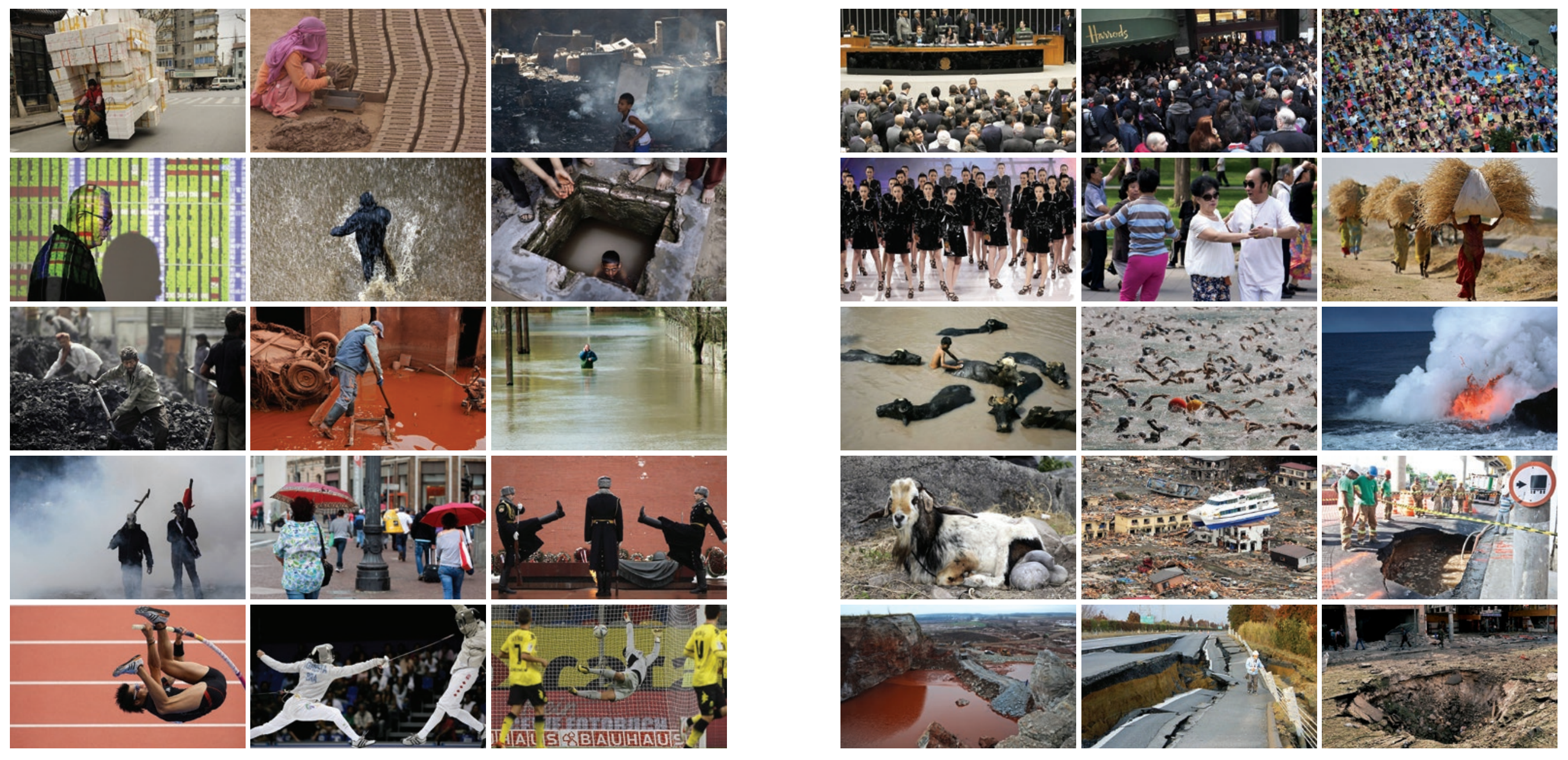


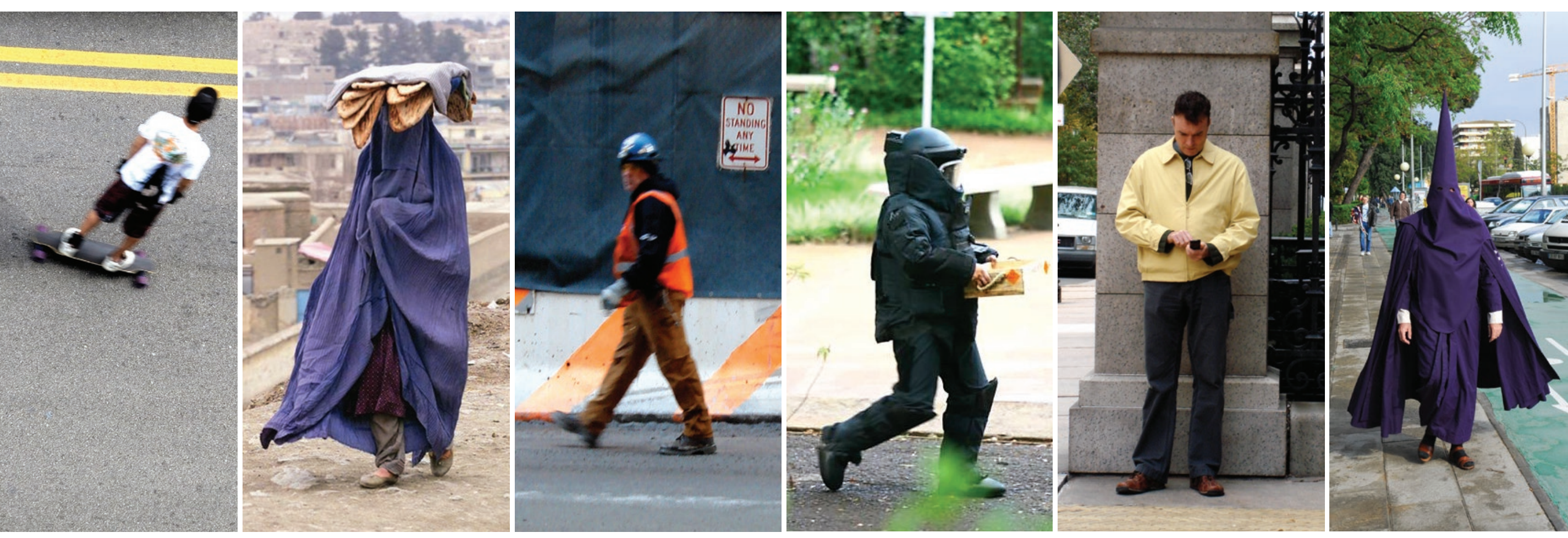




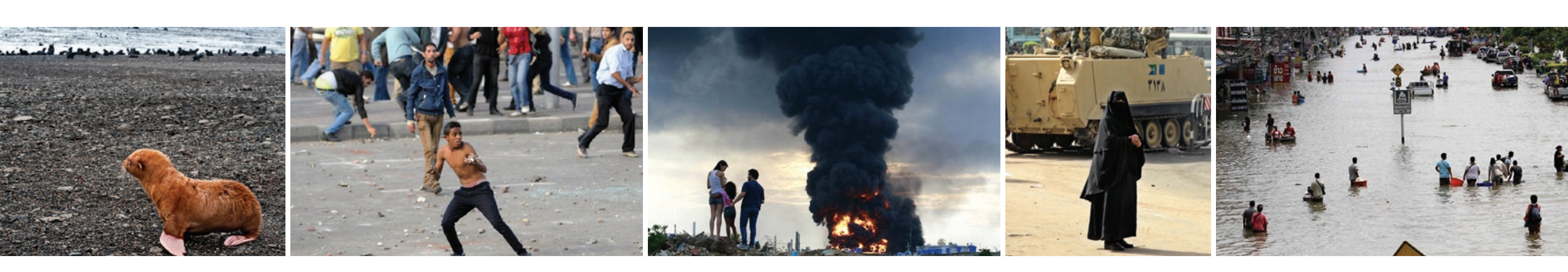

[...] O que realmente se dá, nestes nossos dias, é a possibilidade de conhecer instantaneamente eventos longínquos e, assim, a possibilidade de perceber a sua simultaneidade. $O$ evento é uma manifestação corpórea do tempo histórico, algo como se a chamada flecha do tempo apontasse e pousasse num ponto dado da superfície da terra, povoando-a com um novo acontecer. Quando, no mesmo instante, outro ponto é atingido e podemos conhecer o acontecer que ali se instalou, então estamos presenciando uma convergência dos momentos e sua unicidade se estabelece através das técnicas atuais de comunicação. (SANTOS, 2004, p. 196).

Fico impressionada com as imagens de fatos noticiados. Graves ou não, são testemunhos do desenrolar da História. Causam atração e repulsão, pois combinam fascínio e horror. "Colecionar fotos é colecionar o mundo" (SONTAG, 2004, p. 13). Constato que o olhar curioso tem me ajudado a oxigenar a rede de relações que nutre o processo criativo. A tese Corpo de provas nasce a partir de um propósito de tecer relações. Tenho tendência onívora e mercurial.

Mercúrio, de pés alados, leve e aéreo, hábil e ágil, flexível e desenvolto, estabelece as relações entre os deuses e entre os deuses e os homens, entre as leis universais e os casos particulares, entre as forças da natureza e as formas de cultura, entre todos os objetos do mundo e todos os seres pensantes. (CALVINO, 1990, p. 64-65).
Após a coleta das fotografias, dividi as imagens em grupos ${ }^{6}$. As combinações passaram, então, a evidenciar um primeiro repertório de observações, afetos e estímulos. Tramas que busquei sem saber que sabia o que buscava. Fazer uma coleção é um método de trabalho, porque as escolhas revelam intenções desconhecidas. Cheguei, enfim, a um denominador comum a todas as imagens, formado pelo tripé:

$$
\text { corpo - lugar - situação }
$$

${ }^{6} \mathrm{O}$ agrupamento das imagens segundo critérios relaciona-se com a secundidade da experiência, ou indução. "Entre a primeira e a terceiridade, entre a abdução e a dedução, está a secundidade, a indução, que constitui o outro pilar daquele edifício pragmático: entre a experiência e a teoria surge a pesquisa controlada dos fatos, a etapa na qual aquela pergunta feita à natureza se concretiza. [...]

De certa forma, a surpresa diante do fato leva à geração de hipóteses explicativas abdutivas, na expectativa da geração de uma lei, coloca a indução como etapa necessária de controle daquela experiência e daquela hipótese; para a indução entendida tradicionalmente, o confronto entre abdução e dedução, entre fato e lei, leva a uma inversão na ordem dos fatores: em lugar de procurar fatos que comprovem uma teoria, parte deles para, experimental e controladamente, criar experimentos que possam comprovar a legitimidade de uma hipótese explicativa, até então, apenas possível. É próprio da abdução produzir ideias, à indução cabe testar ideias e falar sobre elas, à dedução cabe generalizá-las e, abstratamente, transformá-las em teorias ou leis" (FERRARA, 1999, p. 160-161). 
Cenas

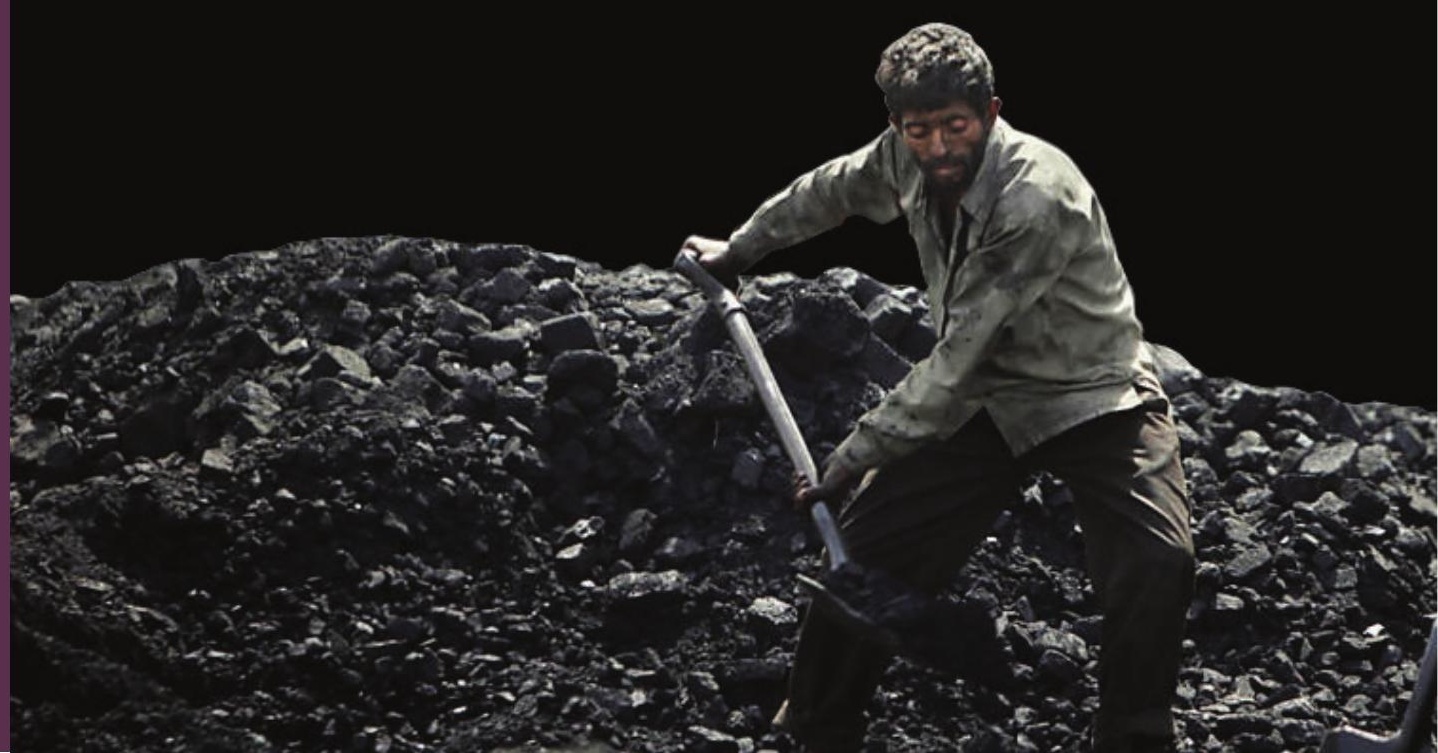



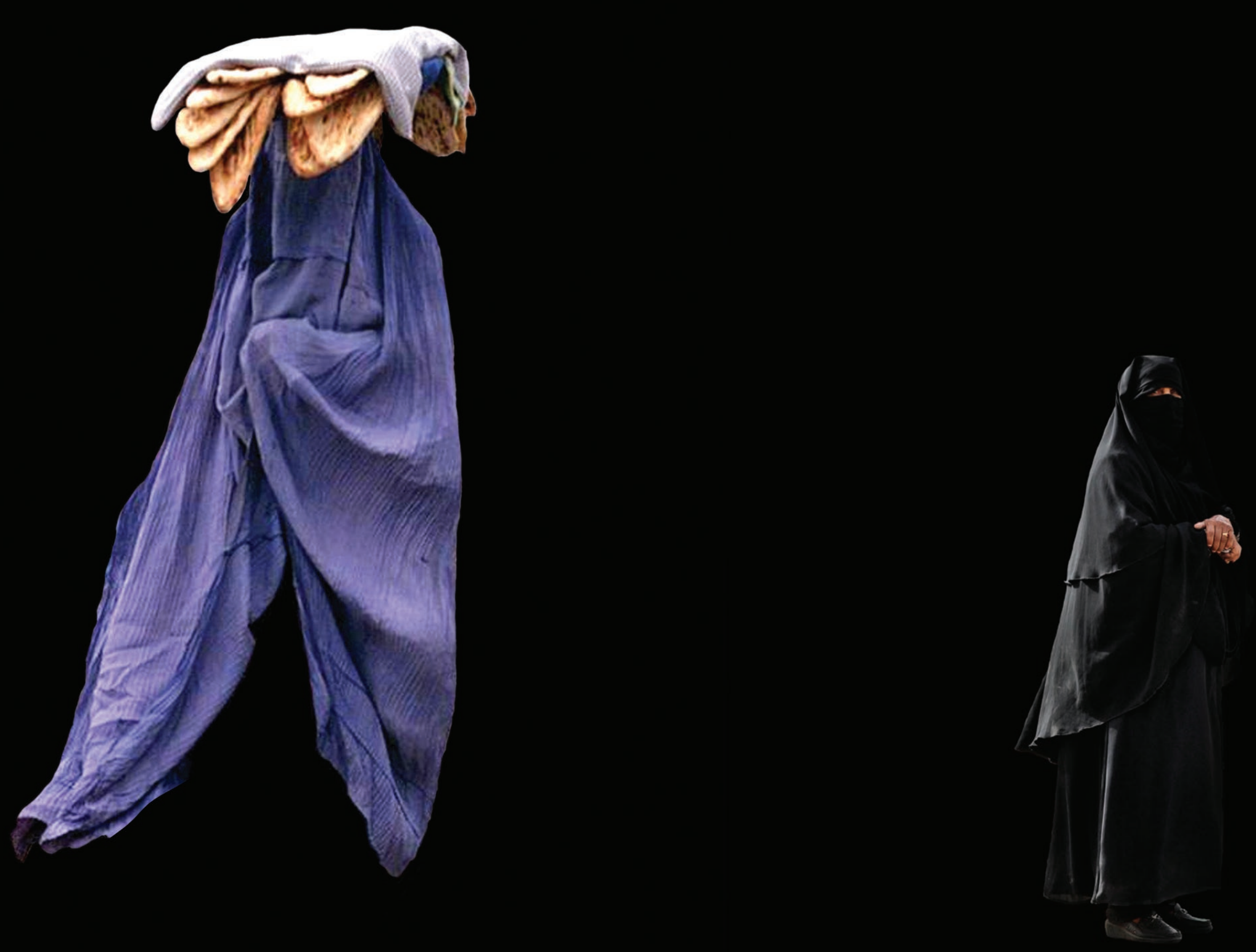

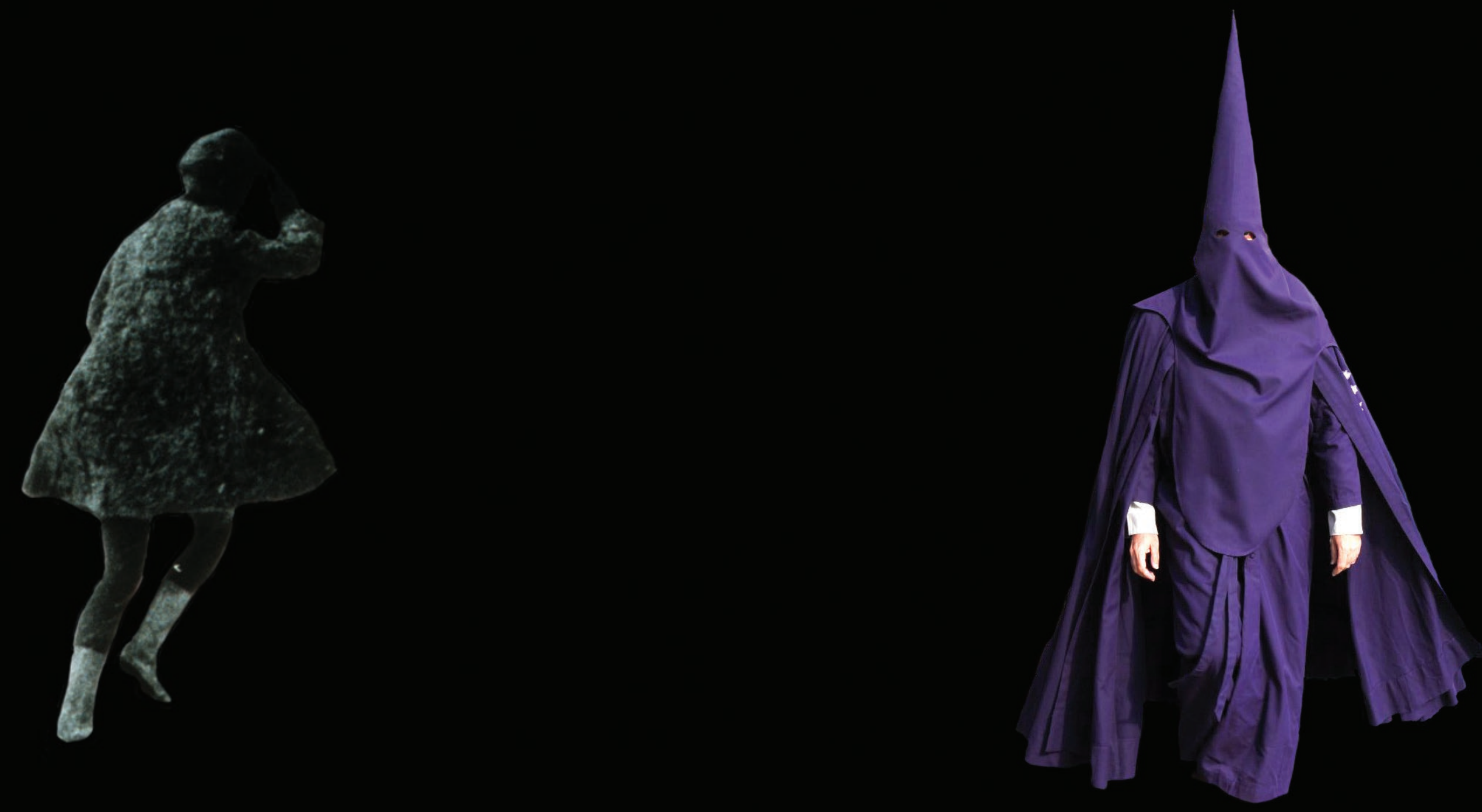

7.7.

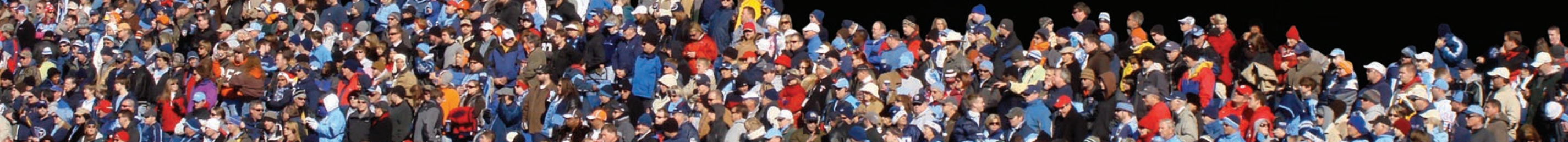

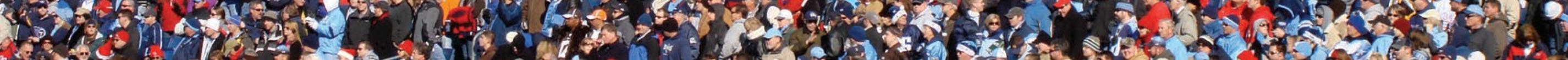

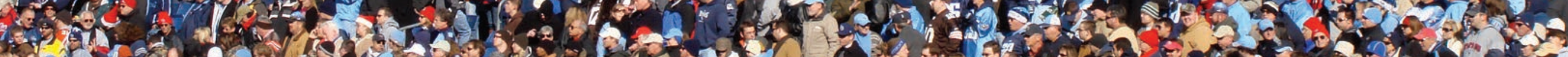

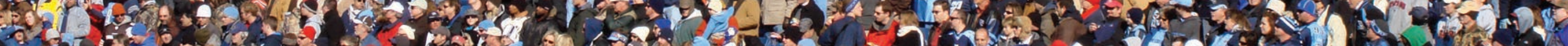

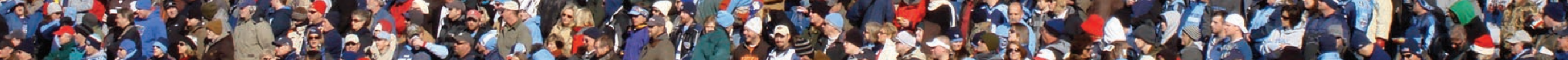

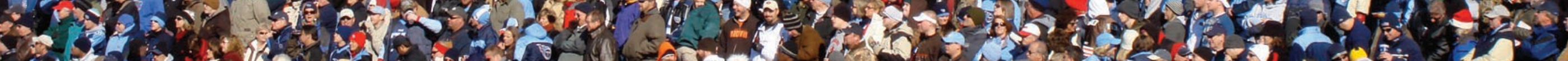

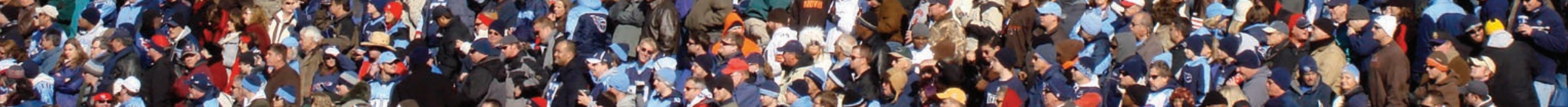

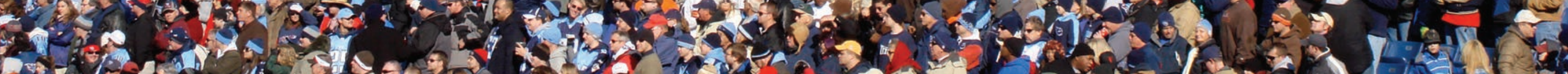

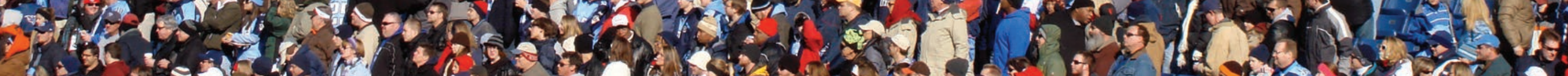
1. 


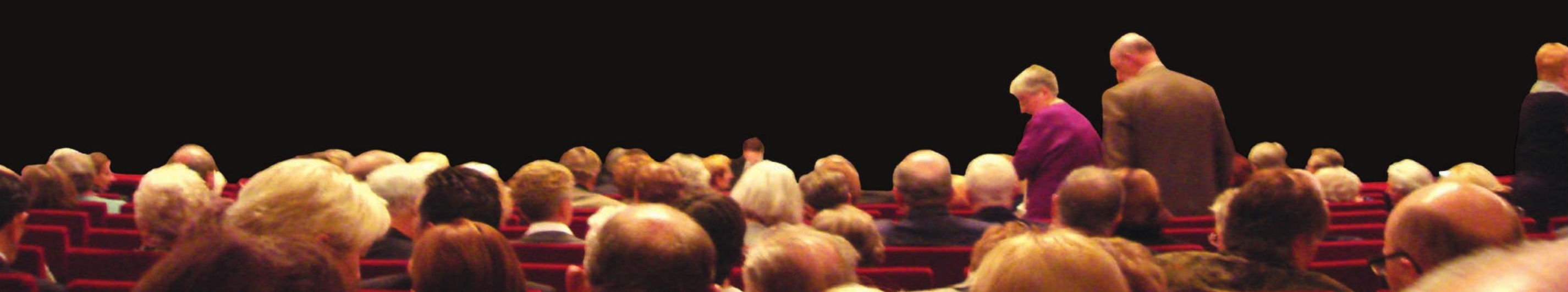




\section{Recortes de espaços e tempos}

Durante a fase de coleta de fotografias que constituíram o arquivo, já surgia o intuito de intervir nas imagens através do recorte, isolando algumas partes, assim como procedi na série Vazios. $\mathrm{O}$ ato fotográfico é um corte temporal e espacial - uma "fatia de espaço-tempo" (DUBOIS, 1993). Recortar partes de uma fotografia é também, de certa forma, insistir no fracionamento do espaço e do tempo. Quando retiro a imagem de uma pessoa do contexto da cena em que ela foi fotografada ou recorto um trecho da imagem da paisagem, posicionando-os no vazio do campo visual, crio um estado de suspensão: um outro tempo, em um não lugar. O procedimento de recorte e colagem de imagens fotográficas produz um estranhamento ao romper com as leis da perspectiva, ao alterar a escala natural das coisas ou evidenciar uma luz cuja origem não mais se identifica. "O regime de verdade próprio da fotomontagem tem como base a infração, $o$ desvio, a construção, o artífice - a arte." (ROUILLÉ, 2009, p. 329).

\section{Diálogos:}

\section{Fotomontagens}

[...] combinar recortes de fotografias, de modo a obter uma imagem que seja, ao mesmo tempo, absurda e absolutamente credível: um trompe

l'oeil que se transforma num trompe-l'esprit.

(ARGAN ${ }^{7}$ apud

JUNIOR, 2006, p. 38).

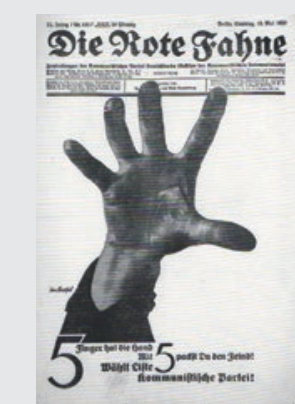

John Heartfield The Hand Has Five Fingers, 1928

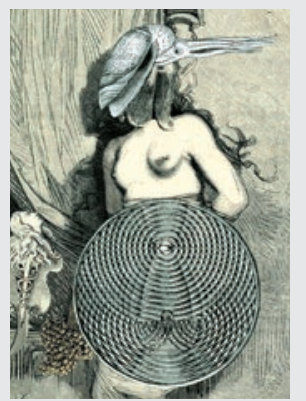

Max Ernst

La clé des chants $1 \mathrm{da}$ série Une semaine de bonté, 1933

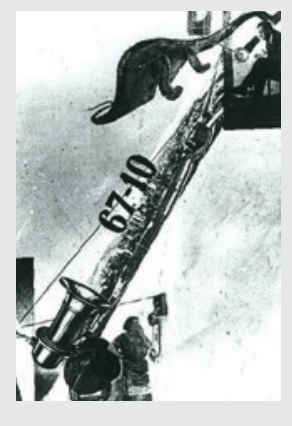

Alexander Rodchenko Fotomontagem para poema Pro Eto de Vladimir Maiakovski, 1923 
Na série Vazios, trabalhei inicialmente deixando o fundo branco em torno das figuras recortadas. Ali, o branco é a expressão da materialidade do papel, é o espaço da página de um livro, ou de uma tela de pintura. Ao retomar esta série, experimentei alterar a cor do fundo do branco para o preto. O trabalho transformou-se: o fundo preto atribuiu ao espaço vazio uma qualidade de espaço cênico. Quando posiciono a imagem da figura recortada à frente do fundo negro, a luz captada inicialmente pela fotografia assemelha-se à iluminação teatral, com foco incidindo sobre o ator em cena.

Não é, porém (parece-me), pela Pintura que a Fotografia tem a ver com a arte, é pelo Teatro. (...) A camera obscura, em suma, deu ao mesmo tempo o quadro perspectivo, a Fotografia e o Diorama, sendo todos três artes de cena. (BARTHES, 1984, p. 52-53).

Imagens traduzem eventos em situações, processos em cena (FLUSSER, 2011). Eu já havia tido alguma intuição sobre os vínculos entre fotografia e teatro quando, ao observar e fotografar trabalhadores agindo sobre o espaço urbano - escavando, usando britadeiras, recolhendo lixo, cortando árvores, carregando entulho ou cumprindo papel similar no script da cidade -, comparei seus gestos e ações à movimentação de atores em um palco.
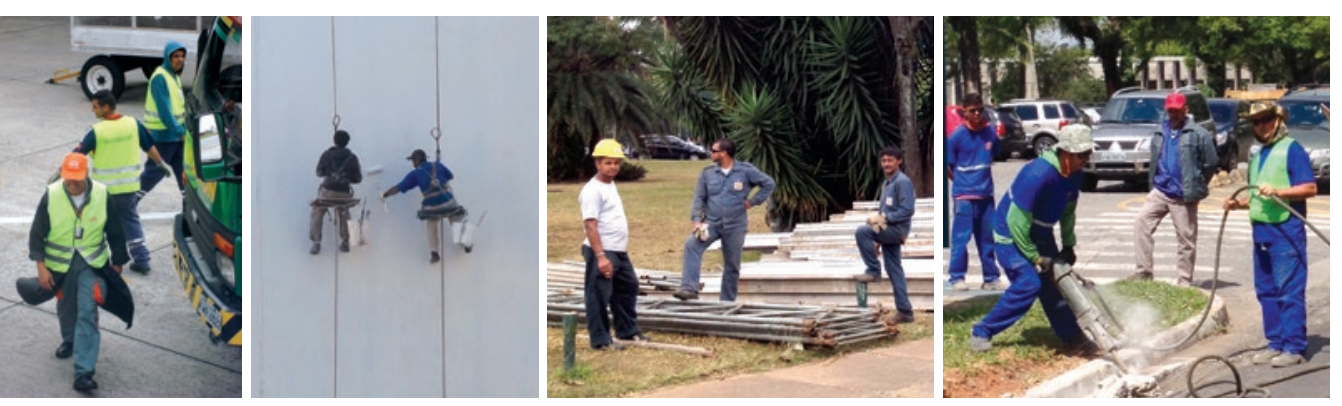

\section{Diálogos: Fundo negro}

Philip-Lorca diCorcia

\section{Cabeça $n^{\circ} 7$}

Pessoas comuns andando na rua recebem um facho de luz e são fotografadas sem saber. A iluminação e o espaço escuro em torno da figura remetem ao espaço cênico.

Na imagem, o mundo é o palco, e as pessoas, protagonistas de suas vidas.

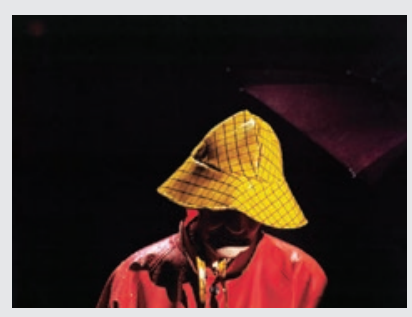

Philip-Lorca diCorcia Cabeça $n^{\circ} 7,200$ Fotografia

\section{Geraldo de Barros}

Sobras

Tensão entre a objetividade da câmera e a intervenção plástica que reconstrói o tempo da memória, alheio ao tempo cronológico

Francisco Goya Caprichos

O lugar ficcional do teatro, cenário para liberdade poética, imaginação e fantasia.

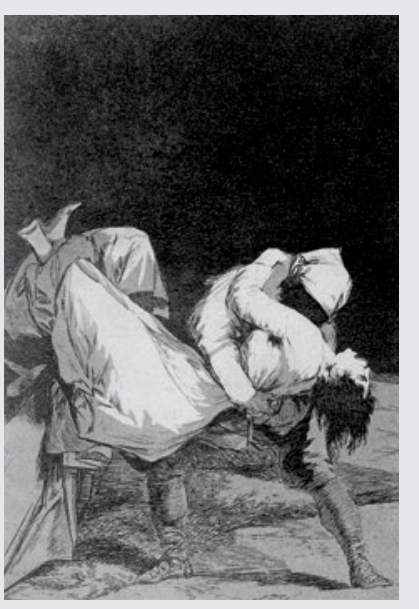

Francisco Goya

Capricho No. 08 Que se la llevaron!, Gravura em 1797-1799
(JUNIOR, 2006). Paisagens inventadas, revisitação de fotografias tiradas no passado, memória, gesto de recortar, mínimo significante que sobra, silêncio.

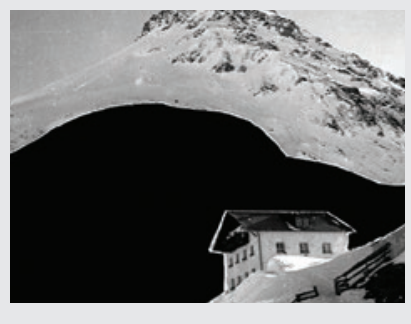

Geraldo de Barros

Sobras, 1996-1998

Colagem 
Fiquei encantada com a potência da cor preta utilizada como fundo para as imagens recortadas. Recortei várias das imagens selecionadas em sites da internet para experimentar mais possibilidades deste novo ambiente cenográfico conformado a partir do fundo negro. Cortei personagens com trajes específicos, religiosos e incomuns, unidos pela estranheza de suas roupas-figurino. Coexistência, cultura, diferença - cada um e todos. Distribuí meu elenco no espaço negro, palco do mundo, ficcional e unificador.

Continuei a busca por mais imagens em sites da internet que, com seu arquivo infinito de formas provenientes de todos os tempos e espaços, alimentava a curiosidade e a fluência do pensamento e da ação criativa.

[...] A prática das imagens de imagens, que transforma o fotógrafo em espectador ou em internauta, e que substitui o real por uma imagem, rompe com uma das principais forças da crença na verdade da fotografia de imprensa: o contato físico direto, da imagem e do repórter, com o real. Transferindo o mundo para uma imagem, ela contribui também para a sua irrealidade. $O$ declínio do cara a cara espacial e temporal entre a coisa e sua imagem coincide com o declínio da relação binária, própria da representação tradicional, em prol de uma relação serial: a imagem não remete mais de maneira direta e unívoca à coisa, mas a uma outra imagem; ela se inscreve em uma série sem origem definida, sempre perdida na cadeia interminável das cópias, e das cópias de cópias. O mundo desaparece dentro dessa série, instala-se a dúvida, e confundem-se os limites entre o verdadeiro e o falso. (ROUILLE, 2009, p. 156).
O problema do passeio virtual é a substituição gradativa da experiência direta do mundo pela informação mediada por imagens. Fixa na imobilidade corporal frente à tela do computador, não estava indo a outros lugares, presenciando acontecimentos ao vivo, como teriam feito os fotógrafos viajantes, de cujas fotografias me apropriava. Cara a cara com a tela, tato, olfato, paladar e audição não são solicitados. Perdendo os sentidos, perde-se o que é sentido.

[...] Qual é a relação daquela pedra lá fora (que me faz tropeçar) com sua fotografia, e qual a relação da pedra com a explicação mineralógica sobre ela? A resposta parece fácil. A fotografia representa a pedra na forma de imagem e a explicação a representa na forma de um discurso linear. Isso significa que posso imaginar a pedra se leio a fotografia, e posso concebê-la ao ler as linhas escritas da explanação. As fotografias e a explicação são mediações entre mim e a pedra; elas se colocam entre nós, e me apresentam à pedra. Mas posso também ir diretamente de encontro à pedra e tropeçar nela. [...]

Mas o exemplo da pedra não é muito apropriado para nossa situação atual, uma vez que podemos andar até uma pedra, mas não podemos fazer nada parecido com isso em relação à maioria das coisas que nos determinam no presente. [...] Tomemos como exemplo a informação genética, a guerra no Vietnã, as partículas alfa ou seios da senhorita Bardot. Não temos uma experiência imediata com essas coisas, mas somos influenciados por elas. [...] Como não temos experiência imediata com elas, a mídia torna-se para nós a própria coisa. 'Saber’ é aprender a ler a mídia, nesses casos. (FLUSSER, 2007, p. 111-112). 
Corpos de água

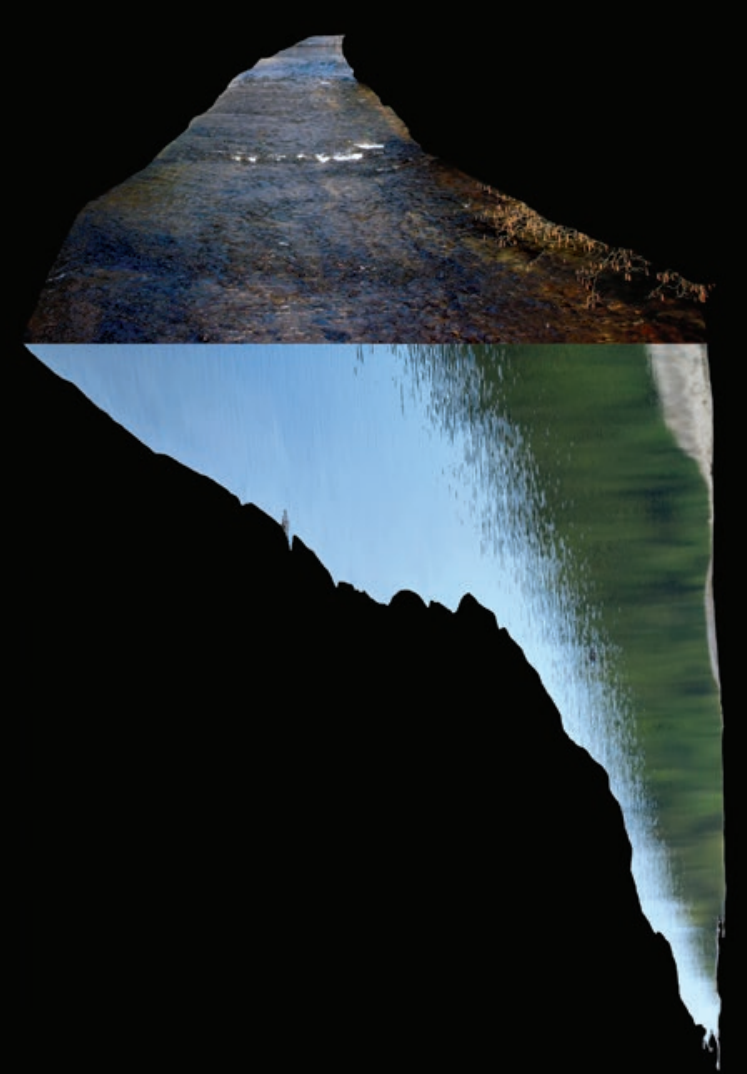




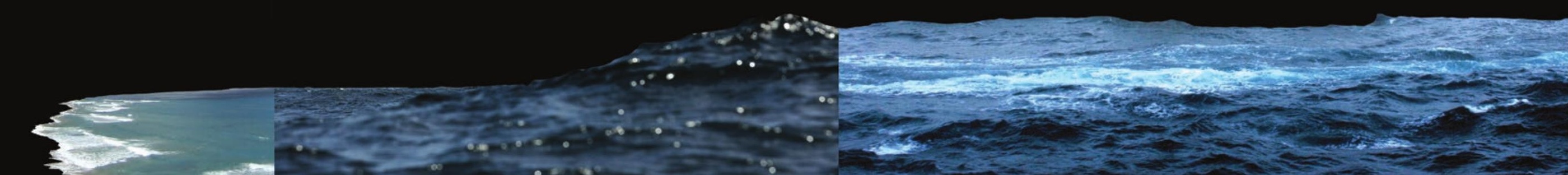




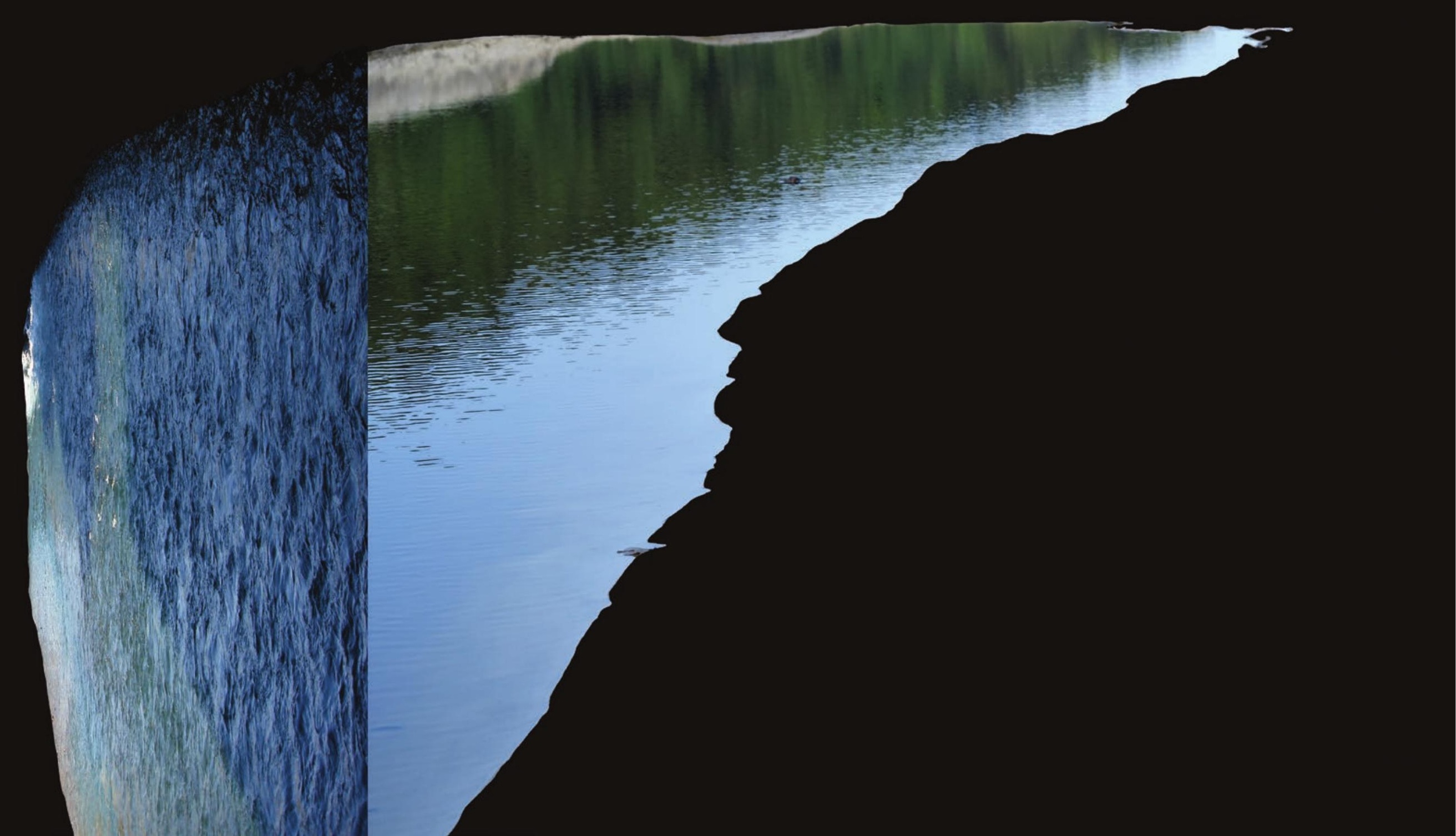




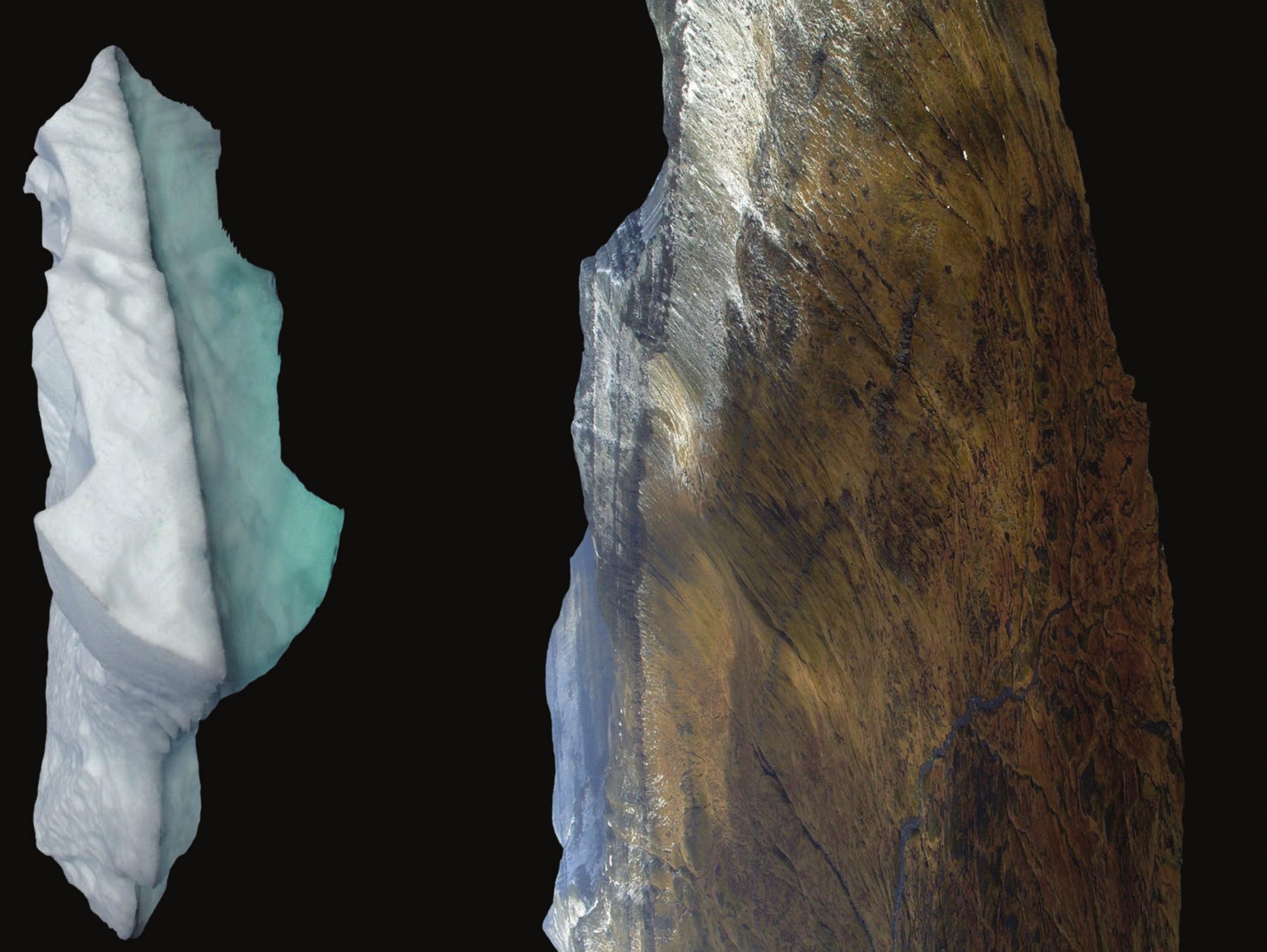




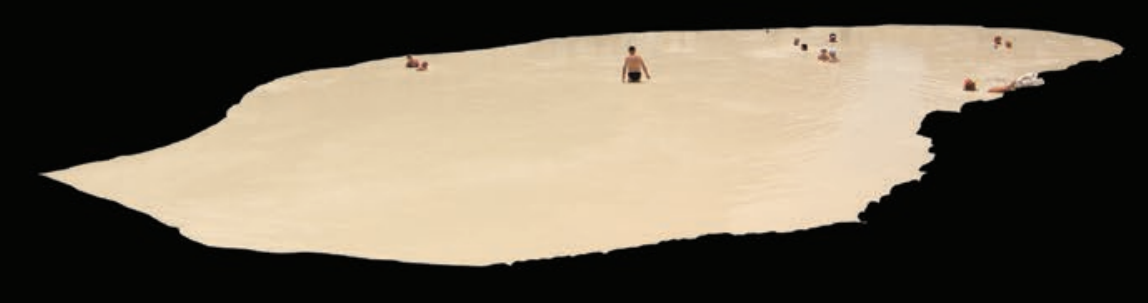




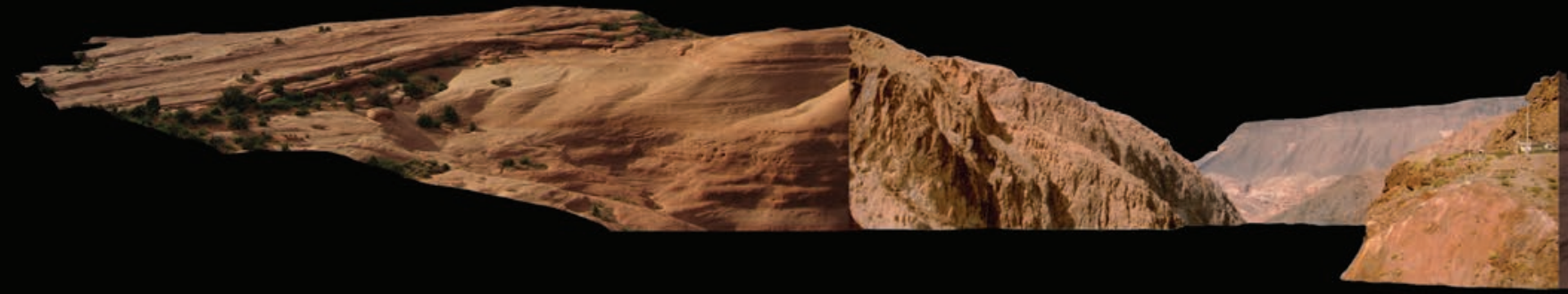


Em busca de novos sentidos, me motivei a ir a campo e tirar minhas próprias fotografias. Voltei de uma viagem para o litoral em que tirei muitas fotos do mar e de relevos na areia. Se comparado com a visão grave de uma senhora de burca à frente de um tanque de guerra no Afeganistão, meu registro de uma onda do mar pode ser considerado irrelevante. Mas estivemos, de fato, ali, naquele dia, eu e a onda, aprendendo com a experiência e não por imagens.

[...] o senhor Palomar não perde o ânimo e a cada momento acredita haver conseguido observar tudo o que poderia ver de seu ponto de observação, mas sempre ocorre alguma coisa que não tinha levado em conta. Se não fosse pela impaciência de chegar a um resultado completo e definitivo de sua operação visiva, a observação das ondas seria para ele um exercício muito repousante e poderia salvá-lo da neurastenia, do infarto e da úlcera gástrica. E talvez pudesse ser a chave para a padronização da complexidade do mundo reduzindo-a ao mecanismo mais simples. (CALVINO, 1994, p. 9-10).

Reuni minhas fotos e outras imagens coletadas de águas, areias, neve, pedras, icebergs. Os contornos da paisagem induziram o desenho do campo visual. Tive a intenção de colocar em xeque a organização das estruturas da natureza, subvertendo a Lei da Gravidade que age sobre os cursos de água, por exemplo. O desenho da página se confunde com o desejo de uma imprevisibilidade. Posicionei trechos de paisagens sobre o campo preto. A perturbação das águas, os reflexos, os volumes dados pela luz e pela cor, tudo ganha intensidade sobre o preto. Corpos de água em curso, escorridos, desdobram-se em outras estruturas não líquidas como rochas, montanhas, planícies, praias. Ainda são imagens? Ou tornaram-se matérias com densidade, consistência e corpo que pedem para se libertar do plano e ganhar o espaço? 


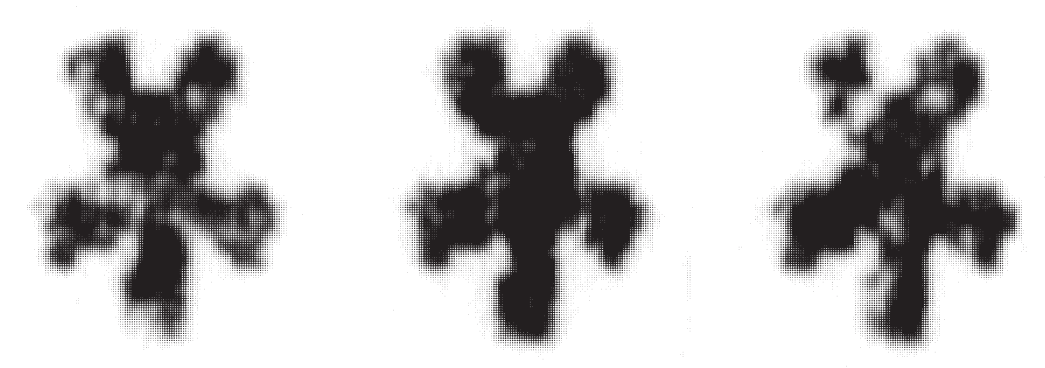

\section{Comprovantes}
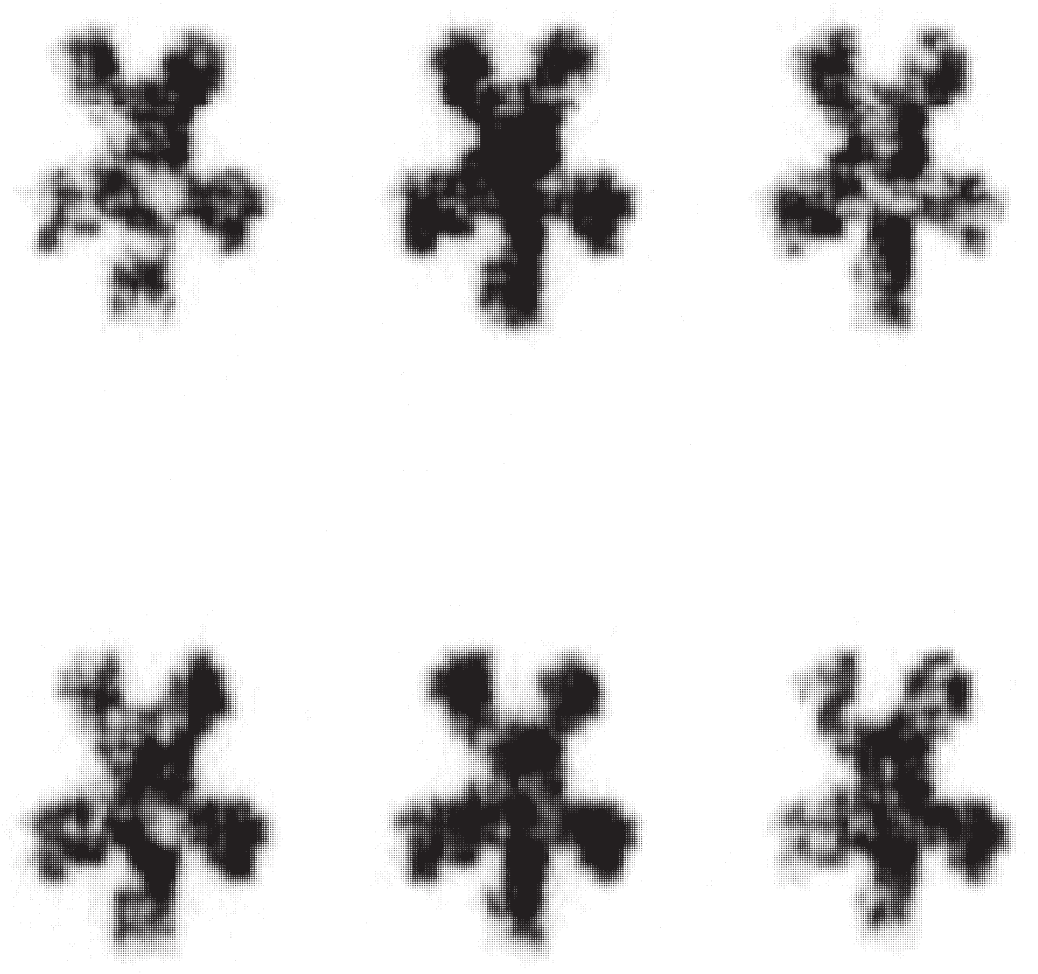


\begin{tabular}{|cc} 
ESTAO & SUJEITOS \\
ESTAO & SUJEITOS \\
ESTAO & SUJEITOS \\
\hline & \\
ESTAO & SUIJIIOS \\
\hline ESTAO & SUJEITOS \\
SSTAO & SUEITOS \\
ESTAO & SUJEITOS \\
\hline
\end{tabular}

$$
\begin{aligned}
& \text { SULEITIS } \\
& \text { SUJEITOS }
\end{aligned}
$$

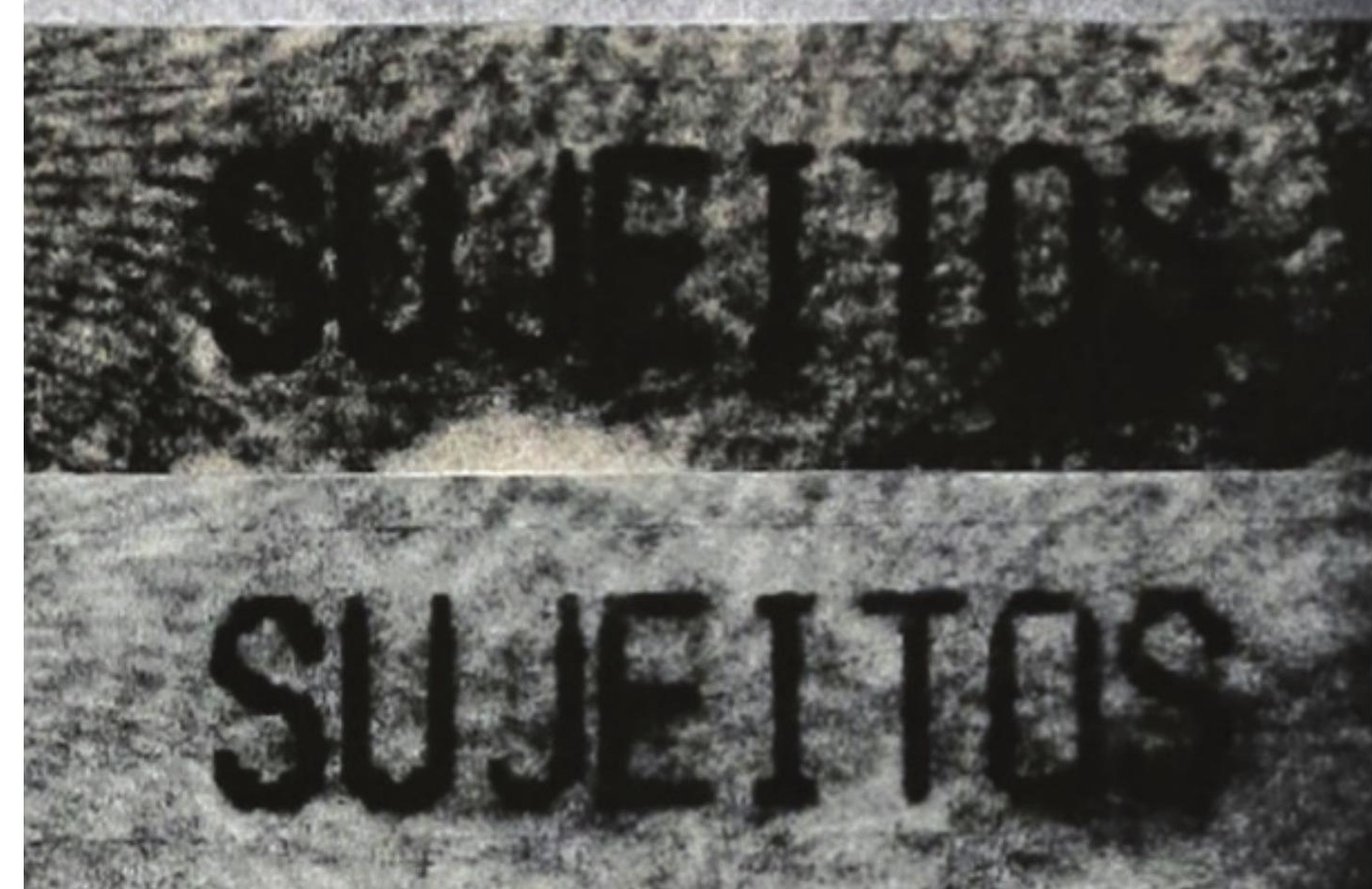




\section{NO DECORRER DO NO DECORRER DE}

\section{PROXIMO DIA}

NO DECORRER DU

\section{PROXIMO}

NO DECORRER

\section{DIA}

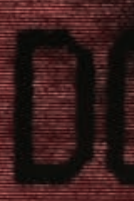



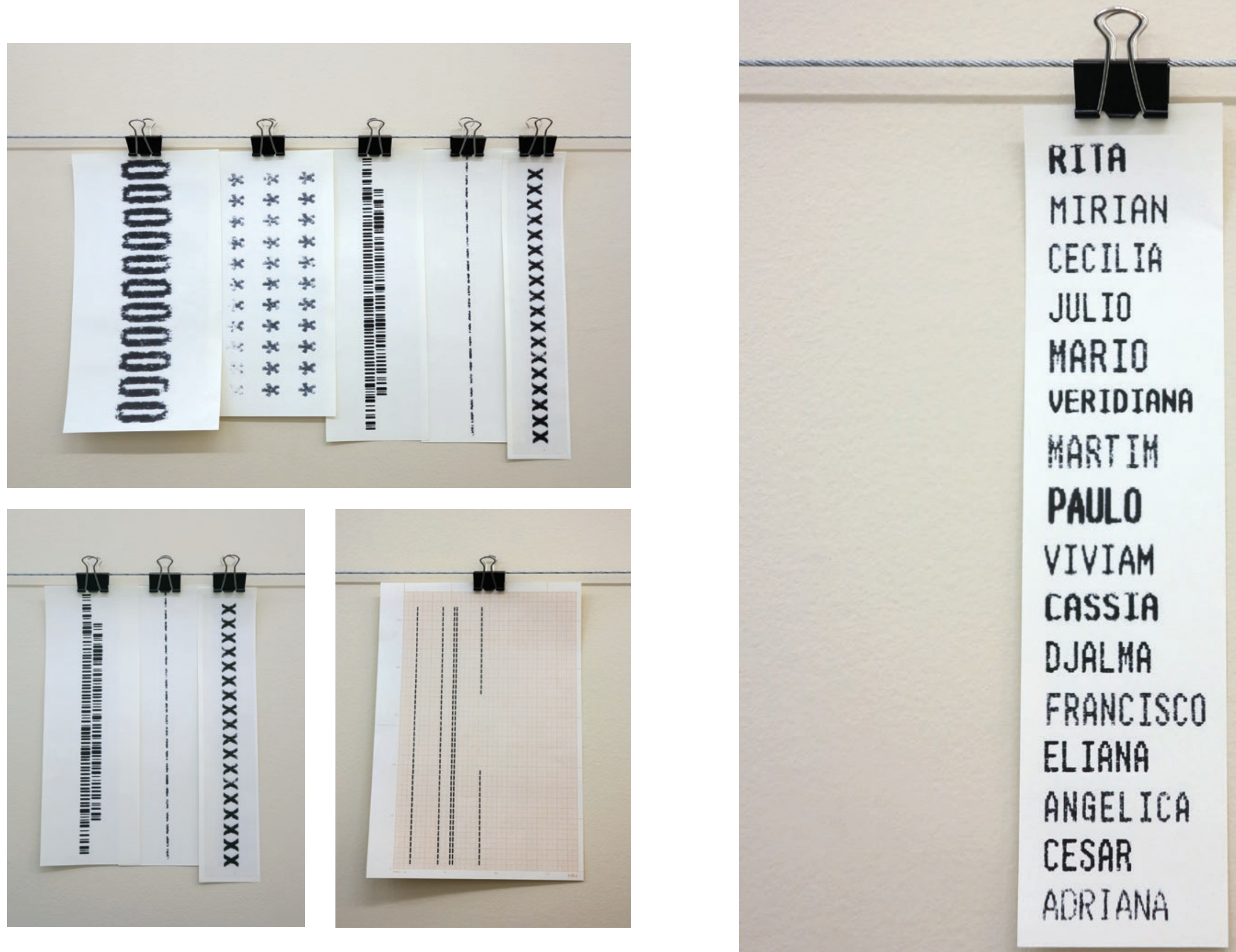

VIVIAM
CASSIA
DJALMA
FRANCISCO
ELIANA
ANGELICA
CESAR
AORIANA


ABOUT YOUR RECENT

EXPERIENCE

OBRIGADO POR ESCOLHER

Evite seu contato

OUUERT TOUS LES JOURS

NO DECORRER DO PROXIMO DIA

NOT REPLACED IF LOST OR STOLEN

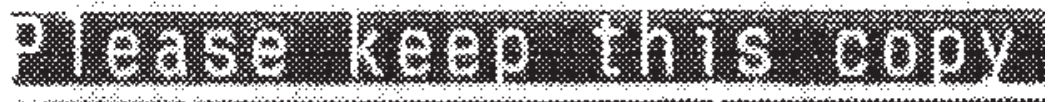

tor your recoris

PRIORITAIRE

TRANSAKTIONS-BELEG
SEM VALOR

ARGENTINA

If undelivered,

RETHAM THIS

YOUR OPINION COUNTS

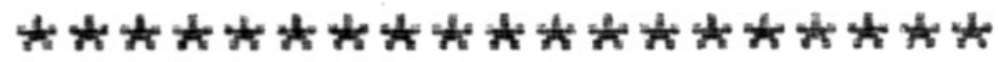

GET CLOSER TO YOUR NEXT VACATION

HELP US

OO PROXIMO DIA UTIL.

STATUS VOCE PODE TER

PENDING 


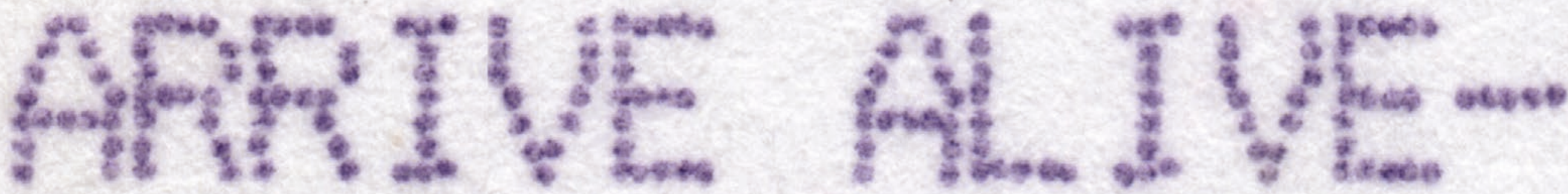

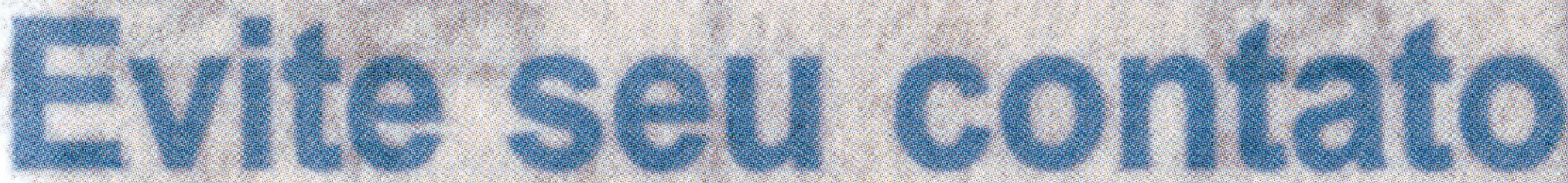

-x)
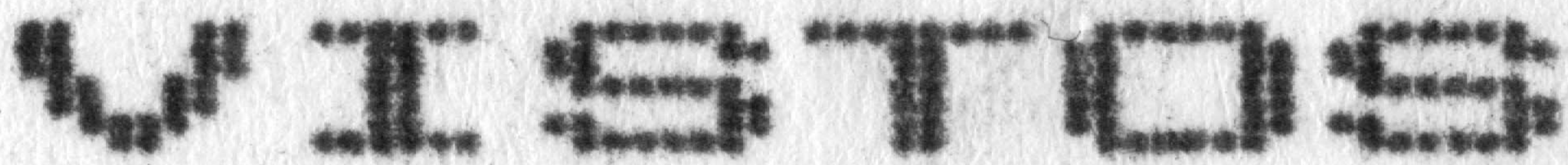


\section{8:23:52 \\ $08: 43: 42$ \\ 09:52:31 \\ $10: 21: 11$ \\ $11: 06: 30$ \\ $17: 06: 34$ \\ $18: 14: 23$ \\ $18: 39: 21$ \\ $19: 06: 59$ \\ $21: 51: 16$ \\ $23: 11: 42$}

1 FETTUCINE CARBONARA

1 PIZZA 4 FROMAGES

1 BADOIT 100CL

1 TIRAMISU MAISON

1 CAFE

THANK YOU FOR VISITING

(604) $331-3731$ \& NEW

GST 137512901

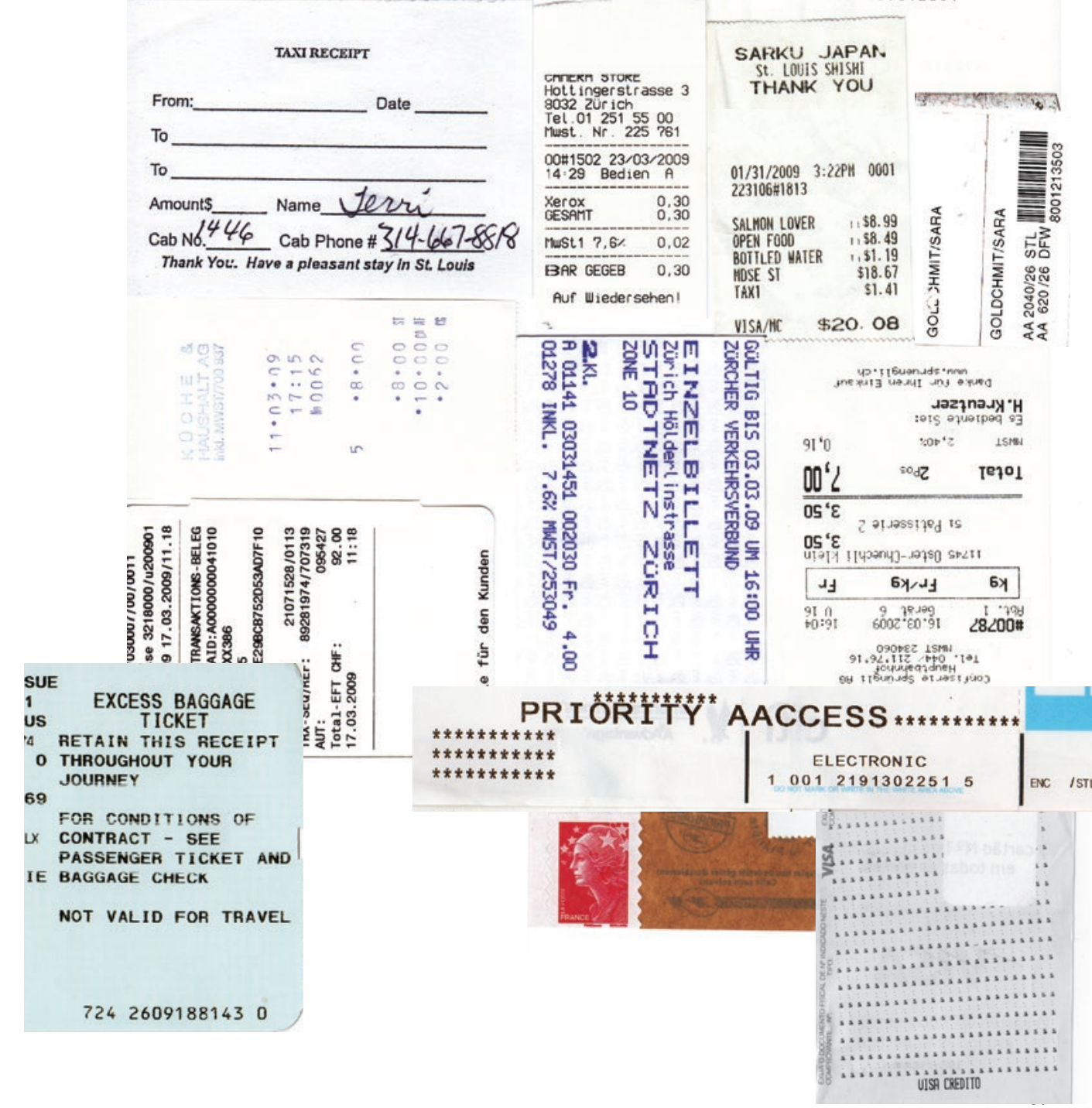


Na verdade não penso em fazer um objeto, uma escultura. Sou contra esse tipo de coisa. Não quero produzir mercadoria. É por isso que sempre fui contra pintar, contra fazer exposições. Quando faço um desenho - do modo como costumo fazer -, faço-o para ser reproduzido e vendo os direitos de reprodução. Isso é muito nobre. É como escrever um poema que em seguida é impresso - não interessa a ninguém a maneira como ele é impresso, não há trabalho físico envolvido no processo. O mesmo acontece com os desenhos. Detesto fazer exposições porque me dou conta de que tudo precisa ser emoldurado, coberto por vidro, acrílico, molduras douradas, molduras de ferro, Deus sabe o que mais. Um desenho precisa ser montado, receber passe-partout; isso sem falar na pintura, para a qual é preciso preparar telas, grandes placas de compensado com as medidas exatas. Em outras palavras, tenho um estoque de mercadoria. Mas escultura é um desastre, desse ponto de vista. Eu certamente não faria um objeto-escultura. Estou pensando em mandar executar o projeto que está no papel, fotografar a escultura e depois destruí-la. Não há razão para ter um objeto - basta um documento ${ }^{8}$. (GLUECK, 1970 apud SARAIVA, 2011, p. 283)

\section{Coletando impressões}

Entre 2008 e 2009, tive a oportunidade de realizar uma longa viagem, visitando diversas cidades dos Estados Unidos e da Europa. Vivi em muitos lugares sem pertencer a nenhum. Estranhei, e também me senti paradoxalmente familiarizada a outros modos de vida e outras culturas. Durante aqueles meses, estava em sintonia com o movimento de pessoas e informações no fluxo ininterrupto das cidades globais. Reconheci a figura do nômade do século XXI.

${ }^{8}$ Declaração de Saul Steinberg em entrevista a Grace Glueck. GLUECK, Grace. The Artist Speaks: Saul Steinberg. Art in America, n. 58, nov.-dez. 1970, pp. 110-117.
[...] a globalização faz também redescobrir a corporeidade. O mundo da fluidez, a vertigem da velocidade, a frequência dos deslocamentos e a banalidade do movimento e das alusões a lugares e a coisas distantes, revelam, por contraste, no ser humano o corpo como uma certeza materialmente sensível, diante de um universo difícil de aprender. (SANTOS, 2004, p. 314).

Hoje, a mobilidade se tornou praticamente uma regra. O movimento se sobrepõe ao repouso. A circulação é mais criadora que a produção. Os homens mudam de lugar, como turistas ou como imigrantes. Mas também os produtos, as mercadorias, as imagens, as ideias. Tudo voa. Daí a ideia de desterritorialização. Desterritorialização é, frequentemente, uma outra palavra para significar estranhamento, que é, também, desculturização. (SANTOS, 2004, p. 328).

Durante essa viagem, surgiram algumas das ideias desenvolvidas na série Comprovantes. Passados alguns anos, com o distanciamento temporal, percebo que desde o início da viagem estive empenhada em coletar impressões ${ }^{9}$. Coletei percepções e sensações resultantes dos fatos vivenciados. E coletei também impressões gráficas das mais diversas, pequenos papéis com os quais me deparava todos os dias - comprovantes, tíquetes, formulários, envelopes, embalagens, bilhetes, passagens, protocolos. Papéis em que textos impressos têm o objetivo de informar, ordenar, confirmar, normatizar, regular, documentar. Não costumamos guardar esses comprovantes: tão logo são impressos, já vão para o lixo.

${ }^{9}$ A palavra impressão possui significados distintos, porém igualmente relevantes para os conceitos discutidos neste trabalho: "sf. 1. Ato ou efeito de imprimir(-se). 2. Marca ou sinal da pressão dum corpo sobre outro. 3. Estado físico ou psicológico resultante da atuação de elementos ou situações exteriores sobre os sentidos; sensação. 4. Influência que um ser ou situação exerce em alguém. 5. Opinião vaga. 6. Art. Gráf. Fixação de texto ou imagem em papel, cartão, etc., para multiplicação, mediante pressão de elementos moldados, gravados, etc., e adaptados a prensas" (FERREIRA, 1993, p. 296-297). 


\section{Caça-palavras}

[...] A mão consome a cultura e a transforma em lixo. Portanto, não são dois mundos que circundam o homem, mas sim três: o da natureza, o da cultura e o do lixo. Esse lixo tem se tornado cada vez mais interessante: diversas áreas do conhecimento, como por exemplo a ecologia, a arqueologia, a etimologia e a psicanálise, têm se dedicado a estudá-lo. O que se constata é que o lixo retorna para a natureza. A história humana, portanto, não é uma linha reta traçada da natureza à cultura. Trata-se de um círculo, que gira da natureza à cultura, da cultura ao lixo, do lixo à natureza, e assim por diante. Um círculo vicioso. (FLUSSER, 2007, p. 60-61)

Inicialmente, interessei-me pela expressão verbal das máquinas registradoras de vendas, programadas para imprimir automaticamente. Percebi o diálogo cotidiano entre as máquinas e os homens, que se dá através da palavra escrita, mecanizada e repetitiva. $\mathrm{O}$ subtexto normativo da vida contemporânea, em qualquer idioma.

Quase simultaneamente à coleta do material, dei início à digitalização dos papéis coletados, com o objetivo de manipular as imagens no computador. Fui formando um arquivo de documentos escaneados, com os quais eu poderia gerar novas estampas através de ampliações, colagens, combinações, justaposições.
No manuseio e observação dos papéis coletados, notei especificamente algumas palavras ou trechos que, quando isolados do contexto em que se encontram, sugeriram poéticas possíveis:

\section{ESTÃO SUJEITOS}

\section{DIA ÚTIL}

\section{NO DECORRER DO PRÓXIMO DIA}

\section{SE HOUVER DIFERENÇA}

O processo de seleção e isolamento de partes de uma imagem já havia se manifestado em outras séries de colagens fotográficas que tinha produzido anteriormente. Trata-se, em princípio, de uma aproximação: o olhar com lupa. E, depois, procedo com a separação, segundo critérios, para análise. O objetivo é chegar perto das coisas, identificar singularidades. E, então, através do deslocamento para fora do contexto original, ativar algum interesse no detalhe.

[...] procuro limitar o campo do que pretendo dizer, depois dividi-lo em campos ainda mais limitados, depois subdividir também estes, e assim por diante. Uma outra vertigem então se apodera de mim, a do detalhe do detalhe do detalhe, vejo-me tragado pelo infinitesimal, pelo infinitamente mínimo, como antes me dispersava no infinitamente vasto. (CALVINO, 1990, p. 83). 
Encontro o procedimento que denominei "caça-palavras" na obra Cuerpos sin vida, do artista argentino Jorge

Macchi. Ele identifica a recorrência da expressão "cuerpo sin vida" (que significa corpo sem vida, corpo morto, cadáver) em notícias de jornal, recorta as frases e monta com elas uma grande colagem de linhas compridas empilhadas, mantendo a expressão cuerpo sin vida alinhada no centro da obra. Macchi chama atenção para a quantidade de corpos sem vida que coexistem com a nossa vida. Ele nos faz refletir sobre a banalidade da morte e da notícia sobre a morte. Quando vi esta obra de longe, em sua totalidade, a colagem me pareceu também um corpo, flutuando como uma anêmona, em silêncio.

Cuerpos sin vida, 2003

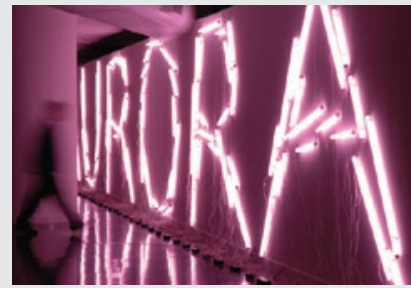

Carmela Gross

Aurora, 2004

[...] Se a palavra poética é aquela dotada de espessura, a palavra que não se curva às demandas da comunicação imediata, oferecendo, em lugar disso, por força de sua carne ampliada, como neste caso, outros sentidos, o

que dizer de uma palavra que assume a nossa dimensão física, para atravessar uma sala como essa da Galeria Olido, interditando-a quase por completo? Como nos demonstra a artista, basta uma única palavra, desde que revisitada sob um ângulo original, re-escrita em relação à arquitetura ou ao próprio espaço da cidade, para que ela se renove por completo, para que passe verter por novos significados, inaugurando mundos e dias novos. (FARIAS, 2004, s.p.)

\section{NOTHING TO LOSE}

A obra Truisms, da artista americana Jenny Holzer, é uma referência importante para meu trabalho. Holzer compilou uma lista de aproximadamente trezentos aforismos, que foram expostos em diferentes mídias ao longo de sua carreira. Compartilho o interesse pelos meios de comunicação de massa. Admiro a eloquência de suas declarações e a maneira como incorpora a expressão verbal - direta e objetiva - no trabalho de artes visuais.
O encanto pela expressão verbal das máquinas registradoras de vendas esteve, desde o início da coleta do material, vinculado ao interesse pela visualidade tipográfica característica desse tipo de impressão. Noto, nessas letras, um desenho frio, próprio da impressão rápida e de baixa acuidade. Imaginei que, quando ampliadas, letras e símbolos gráficos como tracejados ou asteriscos teriam suas qualidades visuais reforçadas. Letras-imagem, também para serem vistas e não apenas lidas.

Observei nestes documentos a presença constante de datas e horários, que documentam fatos sucessivos ou simultâneos.

Em cada lugar, os sistemas sucessivos do acontecer social distinguem períodos diferentes, permitindo falar de hoje e ontem. Este é o eixo das sucessões. Em cada lugar, o tempo das diversas ações e dos diversos atores, e a maneira como utilizam o tempo social não são os mesmos. No viver comum de cada instante, os eventos não são sucessivos, mas concomitantes. Temos, aqui, o eixo das coexistências. (SANTOS, 2004, p. 159)

Realizei montagens com datas e horários provenientes de diferentes momentos, mas que foram então impressos a um só tempo, com a tecnologia da impressão jato de tinta para grandes formatos. A essas montagens dei o nome de Hora marcada. Nestes trabalhos, os momentos sucessivos definidos pelo relógio coexistem no espaço do papel. "[...] Desde já é futuro, e qualquer hora é hora marcada” (LISPECTOR, 1998a, p. 12).

\section{SIEN OF MATURITY}

Jenny Holzer Truisms, 1984 


\section{DIA UTIL.}
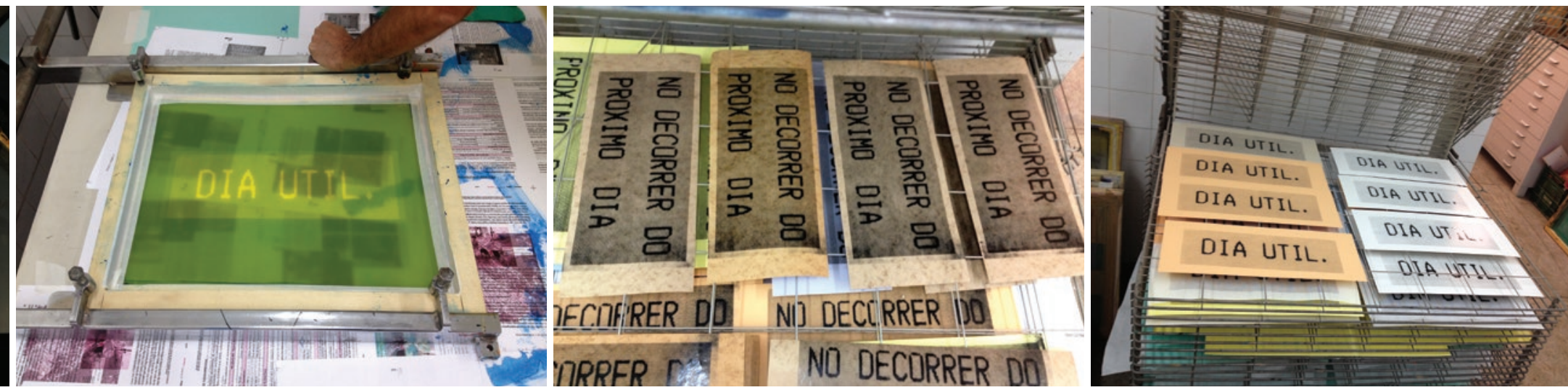

\section{Provas em serigrafia}

Produzi serigrafias a partir de palavras ou trechos de textos pré-selecionados e escaneados. $\mathrm{O}$ trabalho foi desenvolvido no Laboratório de Produção Gráfica da FAU-USP, onde realizei tanto a gravação das telas como a impressão de uma pequena tiragem.

A ideia inicial de encaminhar o trabalho para a técnica de reprodução em serigrafia surgiu do desejo de atribuir novas características materiais às palavras impressas. Queria ver uma camada espessa de tinta transferida para o papel. E com a serigrafia seria possível imprimir em suportes variados e ter diversas cópias a um baixo custo.

O embate com a execução manual, no entanto, apresentou mais dificuldades do que eu poderia prever. Todo o ciclo da produção solicitou-me um empenho muito intenso, tanto em termos do tempo necessário para a execução do trabalho como de esforço para comprar e carregar os materiais, produzir as matrizes com xerox em papel vegetal, preparar a tela para a gravação, gravar a tela, lavar a tela, secar a tela, refilar os papéis, preparar a mesa de impressão, preparar a tinta, entintar a tela, imprimir provas, dispor as impressões na secadora, embalar e guardar as estampas finais...

Talvez eu não questionasse a quantidade de esforço envolvido nas tarefas mencionadas, se o resultado tivesse sido satisfatório. Em primeiro lugar, considerei que a técnica da serigrafia, da maneira como foi empregada - tinta sintética sem relevo sobre papel - não atribuiu uma corporeidade suficientemente distante dos tíquetes coletados inicialmente. Uma hipótese: talvez o formato devesse ser maior. Mas, nas condições em que trabalhei, a serigrafia impôs limites no formato, que ficou condicionado às possibilidades de confecção da tela, ao tamanho da mesa de impressão, à força 
necessária para imprimir. Outra hipótese: talvez eu conseguisse atingir a materialidade desejada gravando as palavras em uma placa de metal ou acrílico, em vez de usar o mesmo suporte (papel) dos documentos originais.

Percebi, afinal, que eu buscava mais a expressão da diversidade das palavras encontradas nos documentos e não tanto uma tiragem de cada estampa. Ao refletir sobre as possibilidades de como mostrar este trabalho, a ideia de justapor as diversas palavras em um grande painel-poema me agradava. A partir dessa ideia, prossegui com o trabalho na técnica da impressão digital para grandes formatos. De qualquer modo, entendi, depois, que os produtos impressos nas variadas técnicas não são obras acabadas, mas sim provas que documentam um gesto, no percurso criativo, e que me levaram a outras ações.

Essa relação entre o que se tem e o que se quer reverte-se em contínuos gestos aproximativos - rasuras que buscam completude. No silêncio que a rasura guarda, o artista aprende a dizer aquilo que resiste a se materializar, ou a dizer de novo aquilo que não lhe agradou. O combate do artista com a matéria nessa perseguição que escapa à expressão é uma procura pela exatidão e precisão em um processo de contínuo crescimento. $\mathrm{O}$ artista lida com sua obra em estado de permanente inacabamento. (SALLES, 2004, p. 78).

\section{Provas digitais}

Acompanho o aprimoramento recente da indústria da impressão digital no Brasil e enxergo muitas possibilidades criativas no uso dessas novas tecnologias. Hoje podemos imprimir diretamente so- bre os mais variados suportes, como papéis de diversas gramaturas e superfícies, tecidos, chapas de madeira, chapas de poliestireno, alumínio e até sobre espelhos.

Para o desenvolvimento da série Comprovantes, primeiramente fiz algumas experiências na impressora jato de tinta caseira, utilizando o papel Fabriano Schizzi. Em seguida, produzi cópias em gráfica digital, utilizando a impressora jato de tinta sobre papel roller, com o intuito de materializar não só formatos maiores, mas também suportes mais ásperos e espessos.

A impressão digital prescinde da matriz, ou seja, não é necessária uma tiragem que justifique a existência do molde. Sobretudo, a agilidade do processo de produção estava mais alinhada a minha disponibilidade para a execução desse trabalho.

A experiência figurativa oferecida pela manipulação da imagem digital, em softwares de computador, agregada às tecnologias limpas de impressão digital sempre se encaixaram muito bem no meu projeto artístico. Essas são as práticas do meu dia a dia, todos os dias. Quando tento trabalhar nas técnicas artísticas tradicionais pintura, escultura, gravura -, ainda que timidamente, sinto sempre que é preciso ter mais materiais, mais espaço, mais tempo. Em outras palavras: mais comprometimento. Não por acaso, incorporo o desenho e a aquarela a minha rotina com mais naturalidade e leveza.

Antes de ser impressa, a imagem digital é uma informação imaterial. Sua natureza é fluida, pode estar em vários lugares e em nenhum. Ocupa espaço apenas nas memórias - dos humanos e das máquinas. Está disponível para ser alterada, copiada infinitas vezes, estragada, refeita. Não impõe limites de custos, nem de espaço. Em alguns casos, o tempo de sua fatura pode ser resumido a poucos segundos: é o tempo de um gesto. 
Cor-luz

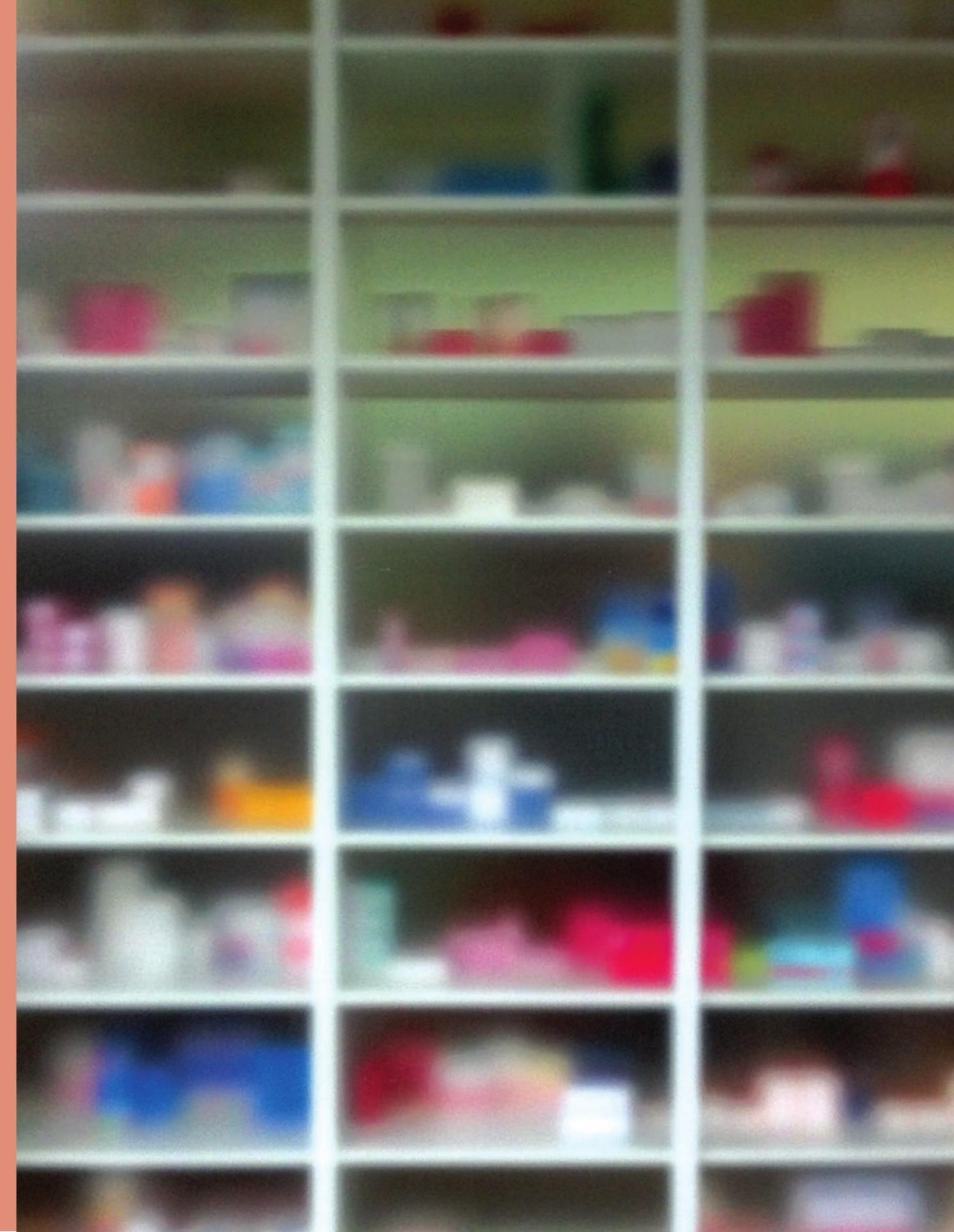




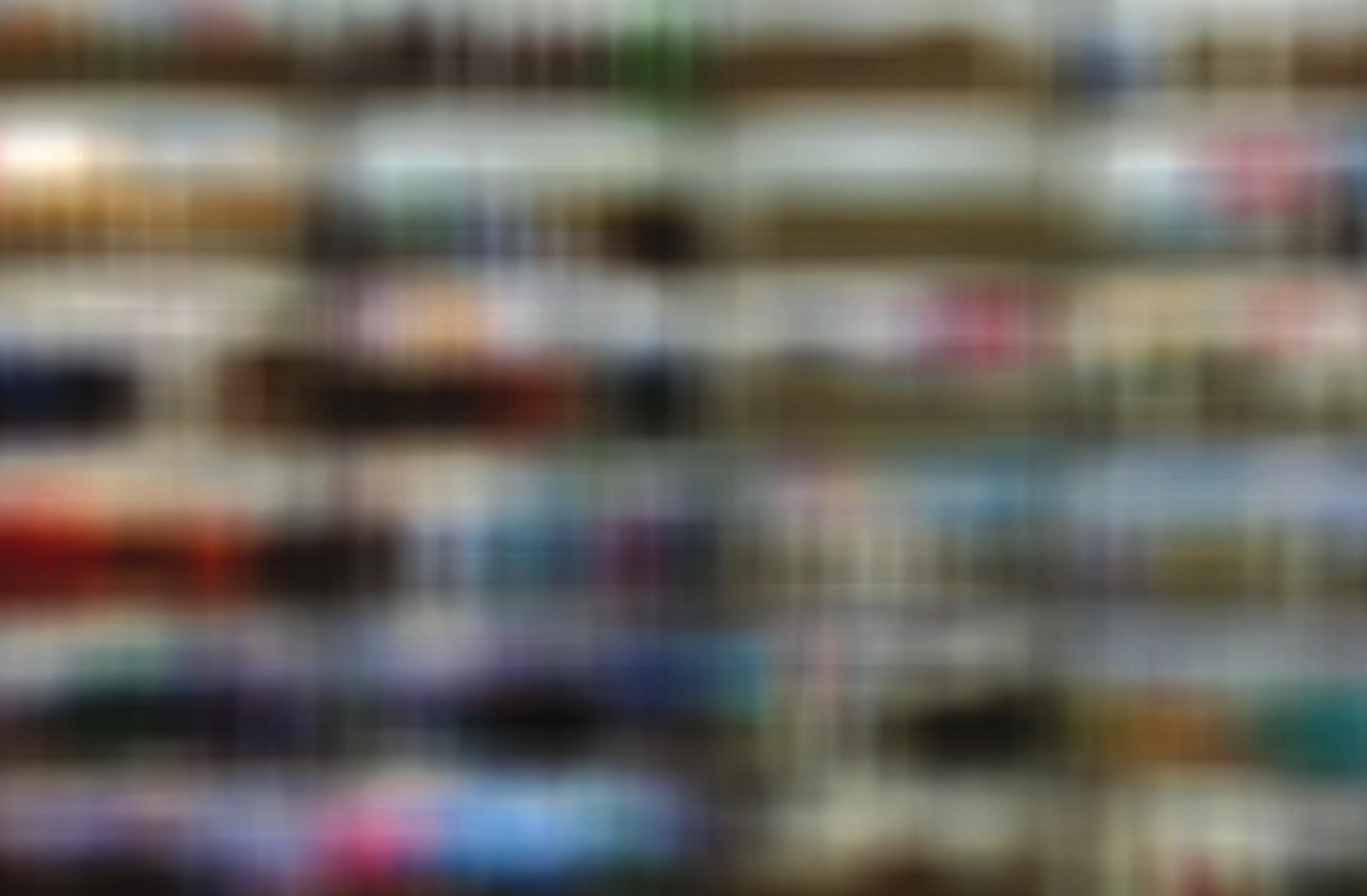





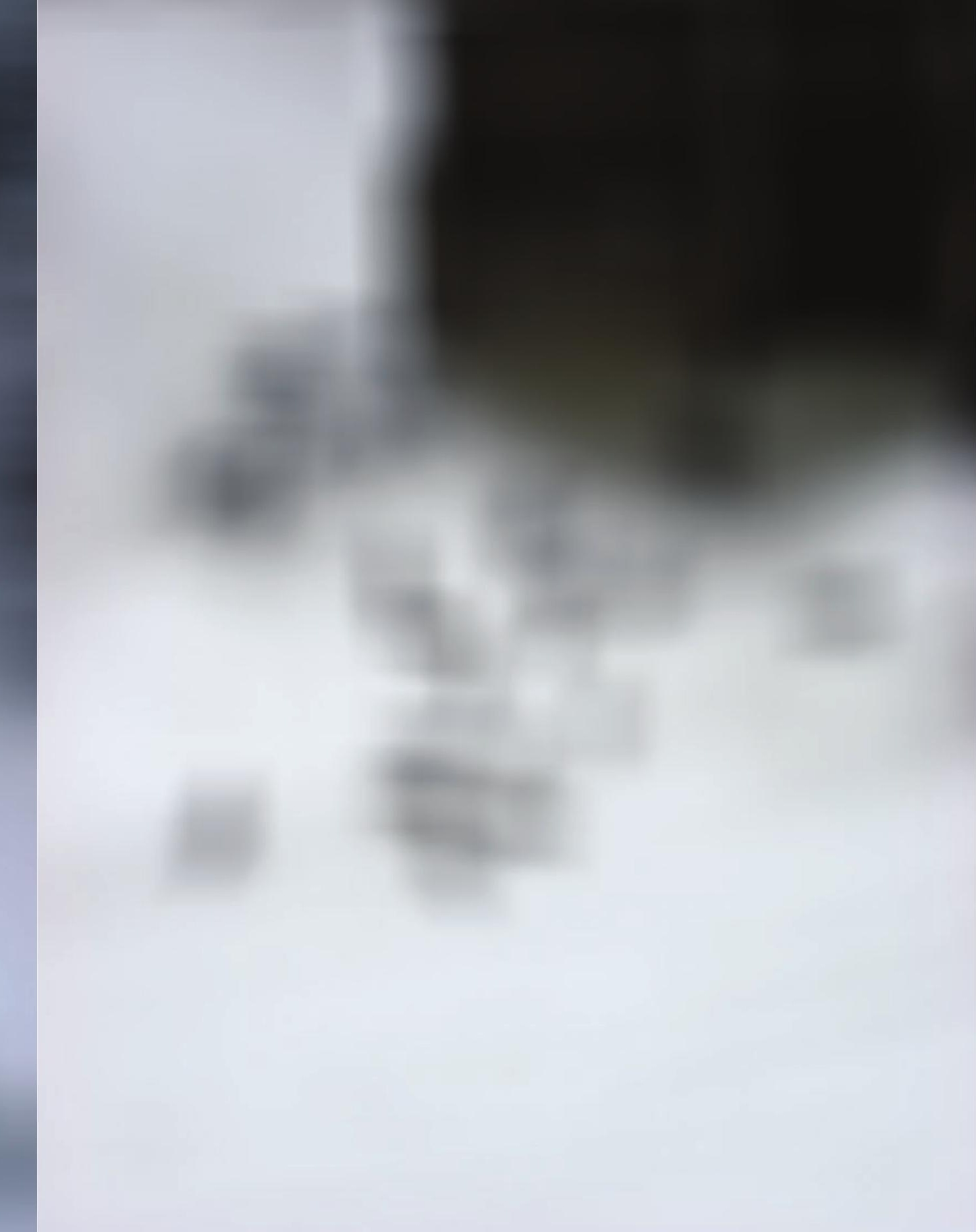




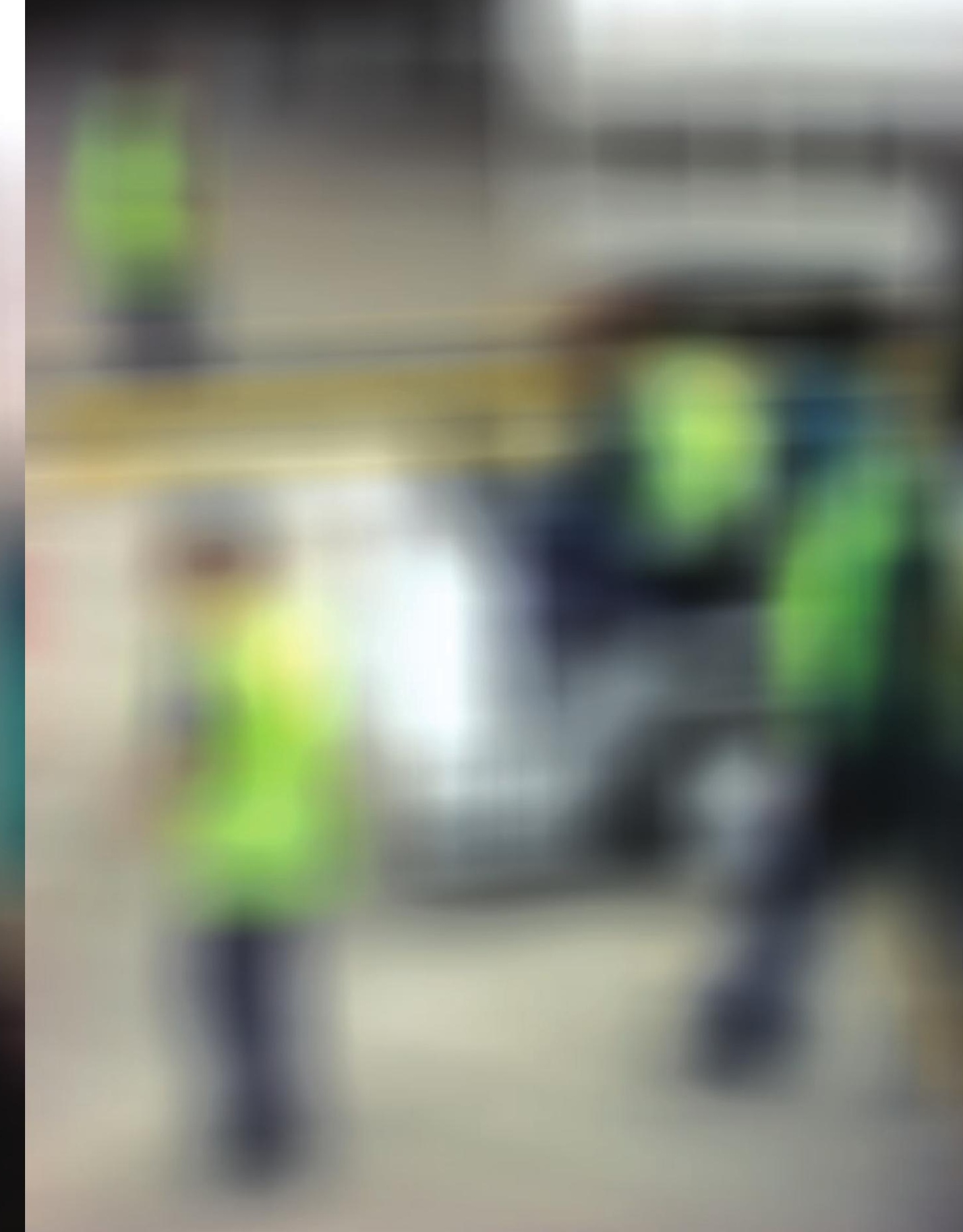





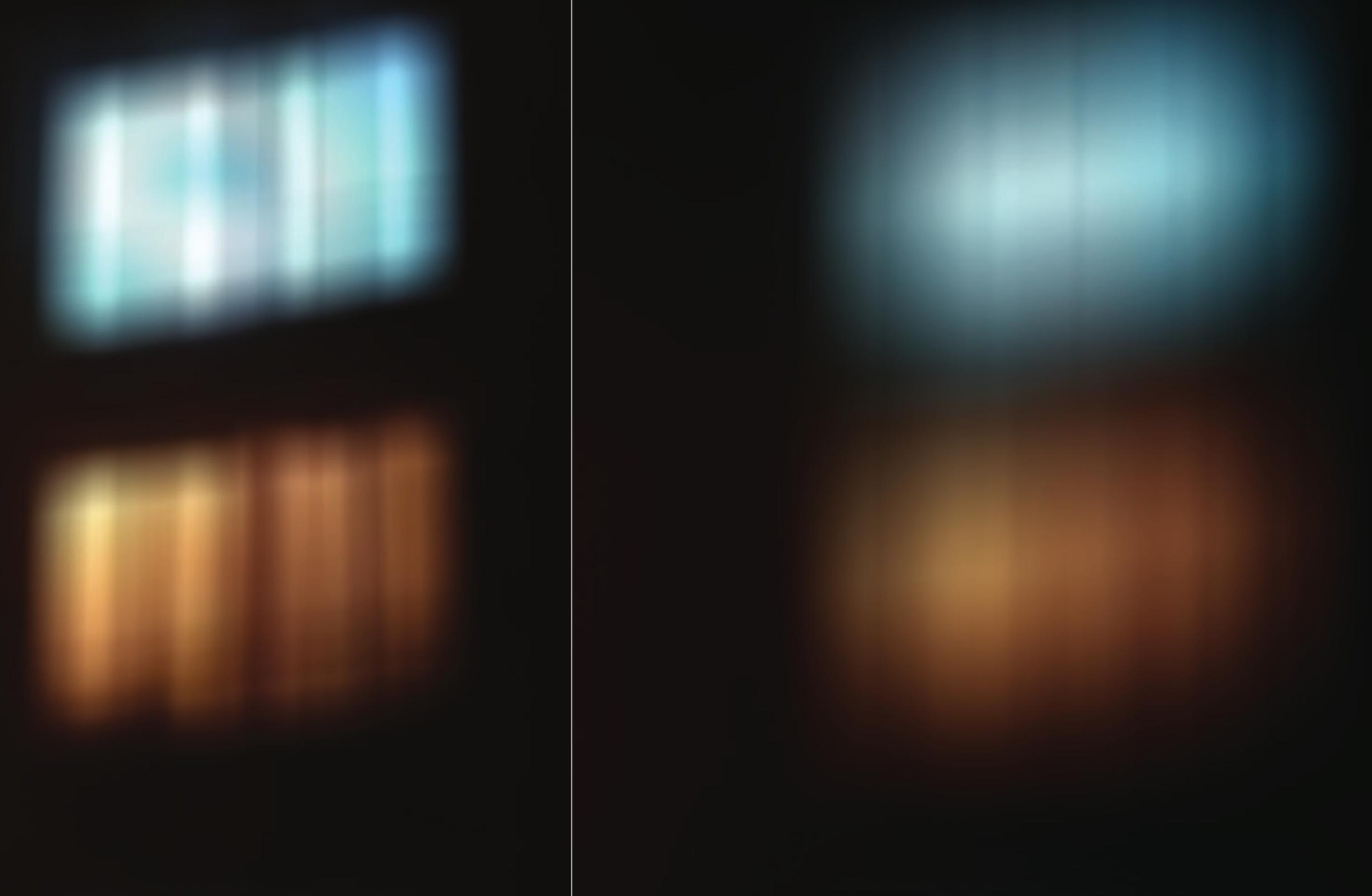



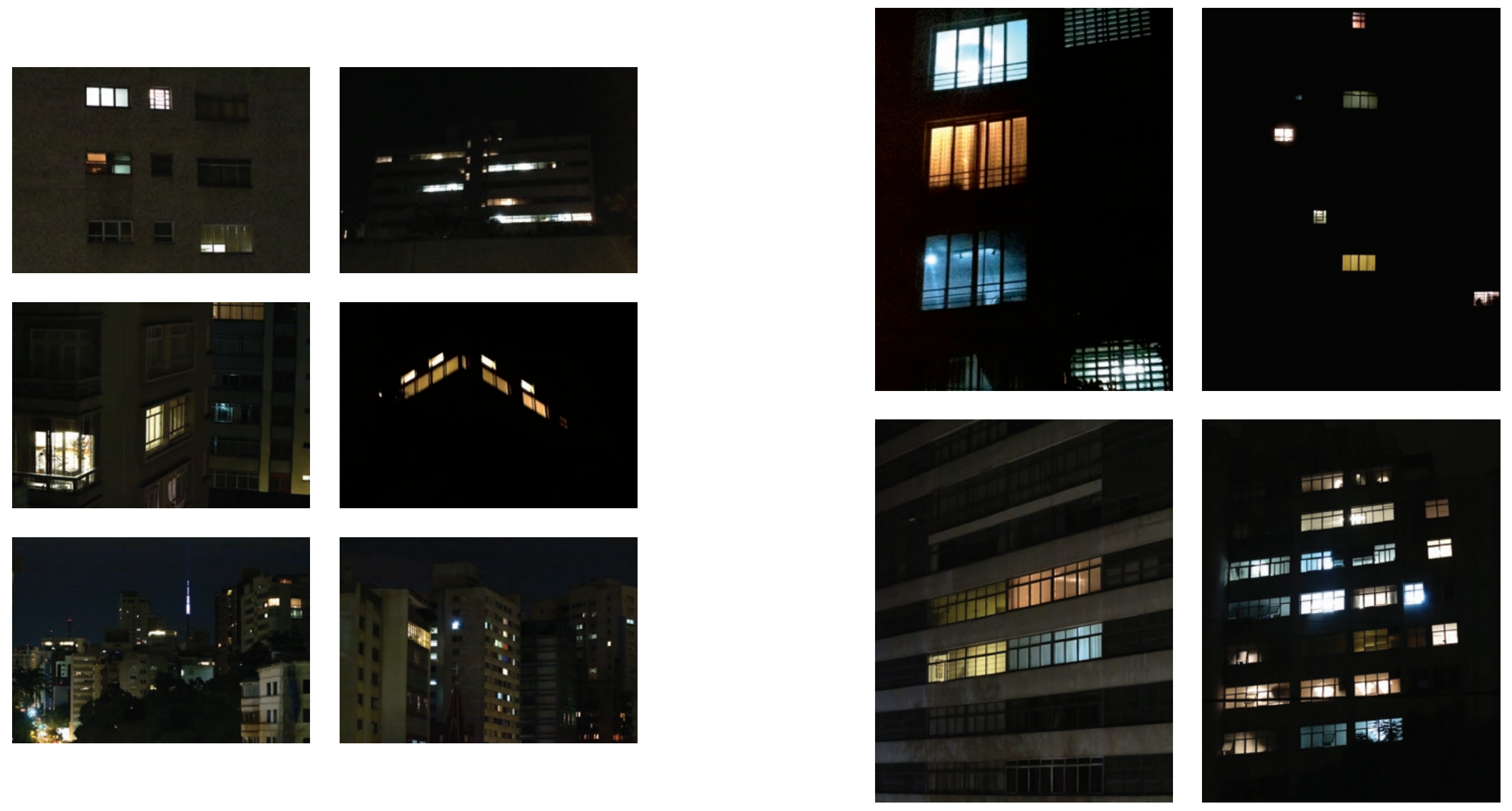

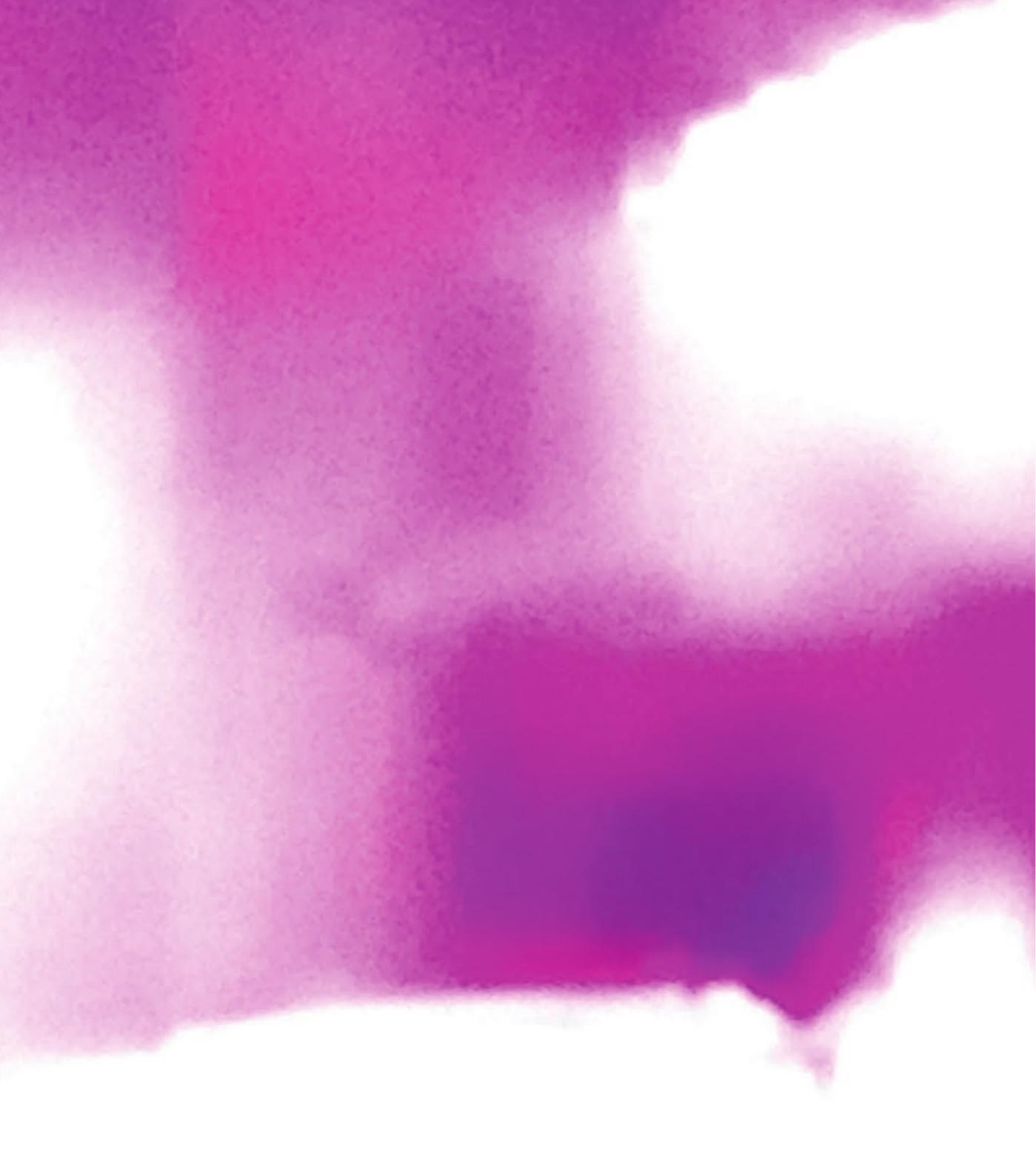

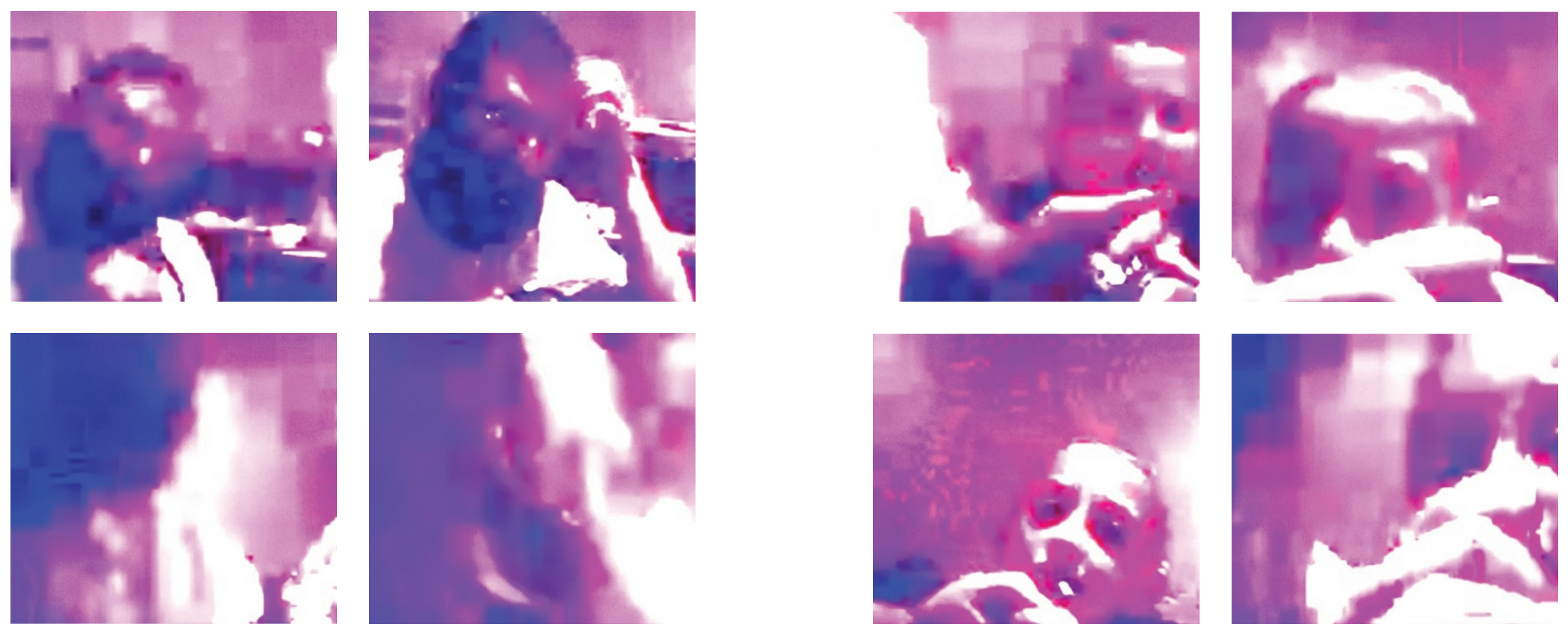


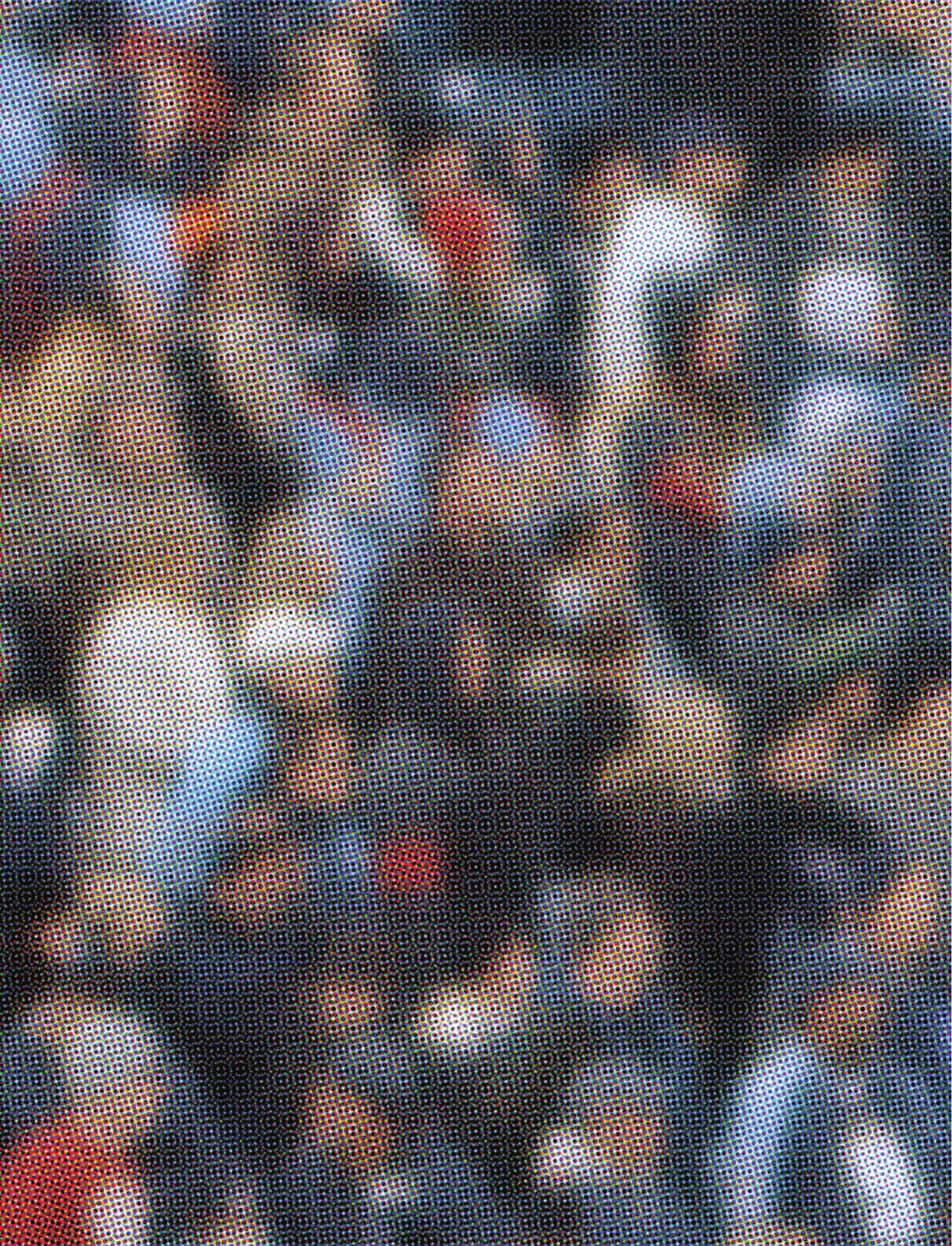

A série Cor-luz $z^{10}$ reúne experimentos de procura por gradações cromáticas e modulações da luz. A fotografia é a escrita da luz. Ao fotografar, tenho intenção de anotar cor, luz e forma.

Faço um exercício de pensamento visual: ao simplificar a representação de um objeto - no limite de suas características essenciais informadas pela cor, luz e forma -, que imagem resultaria? Prossigo com esse exercício do olhar nos objetos que vejo. Quando observo lombadas de livros dispostos em uma estante, imagino sua simplificação sob a forma de faixas de cores em sequência. Quando observo produtos enfileirados em uma prateleira-vitrine, reparo no desenho mínimo das silhuetas no contraluz. Andando na rua, vejo as janelas dos prédios, à noite; poderia sintetizar sua imagem apenas com retângulos de cores iluminados.

Ao fotografar, considero a possibilidade de retrabalhar a foto posteriormente. Nessa série, revisitei também fotografias antigas, de lugares em que estive no passado e que voltaram a me interessar pelas cores e luzes específicas de certas paisagens documentadas nas fotos.

Durante uma chamada por skype, fotografei a tela do computador em que a imagem do meu interlocutor aparecia em baixa resolução. Nesse ensaio, registrei um espectro de cor-luz dado pelas nuances da imagem em um movimento quase indecifrável: comunicação humana codificada e mediada pela tecnologia.

10 "Cores-luz são as que provêm de uma fonte luminosa direta [...]. São elas que iluminam nossas vidas, como a luz do sol, a de uma vela, a de uma lâmpada ou a de uma descarga elétrica. [...] Por síntese denominada aditiva, essas cores produzem o branco." (PEDROSA, 2006, pp. 28-29). 


\section{Diálogos: Fotografia e pintura}

\section{Gerhard Richter}

\section{Fotopinturas}

Pintura realista a partir de referências fotográficas; o

gesto borrado. Obra cerebral, onde o sentido da imagem é sempre colocado em questão (GIANNOTTI, 2009).

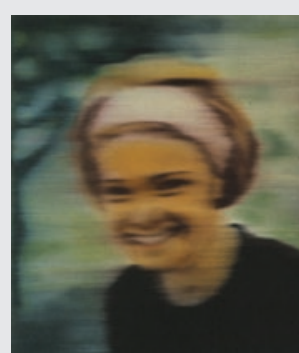

Gerhard Richter

Inge, 1965

Óleo sobre tela
Julia Margaret Cameron Sir John Herschel

Falta de foco em áreas da fotografia, inexatidão, erro técnico que torna a imagem expressiva.

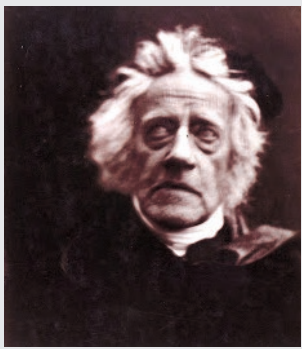

Julia Margaret Cameron Sir John Herschel, 1867 Fotografia

\section{Pierre Cordier}

Quimigramas

Emprego da sintaxe ${ }^{11}$ da impressão fotográfica

(analógica) como recurso artístico, aproximando a fotografia da pintura (FLORES, 2011)

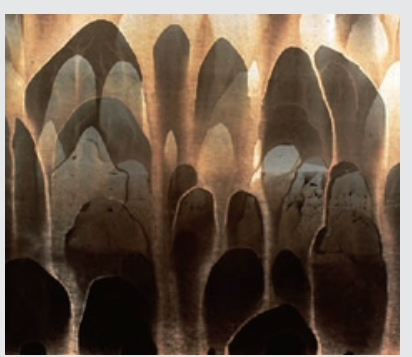

Pierre Cordier Quimigrama, 2007 Fotografia

Outras imagens foram criadas a partir de cenas que preparei com objetos à frente de um fundo branco, com o intuito de fotografá-los e depois desfocar. Com os contornos dispersos, a imagem tende ainda mais à transparência e à imaterialidade. As cores se diluem. Noto uma semelhança com os resultados que habitualmente se obtêm com a técnica da aquarela.

Testei procedimentos digitais conhecidos como filtros, disponíveis em softwares de manipulação de imagens, que alteram a fotografia inicialmente tirada. Experimentei trabalhar especialmente

11 “[...] A linguagem, ou 'sintaxe', de um meio será a soma de todas aquelas marcas, impressões ou rastros que as ferramentas deixam na imagem e que são

com o desfoque, ou blur, que borra os contornos das figuras. Com menos nitidez, menos certeza, deixo apenas um rastro do que existe. Da forma à informa. A matéria dos objetos fotografados torna-se gasosa como um vapor de ar... ou sensação: Cor-luz.

[...] a crescente imaterialidade e a impalbabilidade da cultura já são hoje uma vivência diária. As coisas ao nosso redor estão encolhendo, em uma espécie de 'miniaturização', e ficando sempre mais baratas; em contrapartida, as não-coisas em nosso entorno inflam, como é o caso da 'informática'. E essas não-coisas são simultaneamente efêmeras e eternas. Não estão ao alcance da mão, embora estejam disponíveis: são inesquecíveis.

Em um contexto como esse, as mãos não têm nada a procurar e nada a fazer. Uma vez que a situação é inalcançável, não há nada a ser tocado ou manipulado. A mão, a atividade de apanhar e de produzir, tornou-se aí supérflua. E o que ainda precisa ser apreendido e produzido é efetuado automaticamente por não-coisas, por programas: por 'inteligência artificial' e máquinas robotizadas. Desse modo, o homem se emancipou do trabalho de aprender e de produzir, e ficou desempregado. O atual desemprego não é um 'fenômeno conjetural', mas um sintoma da superficialidade do trabalho nesse contexto imaterial. (FLUSSER, 2007, p. 62).

O meu embate com as técnicas de manipulação e reprodução da imagem - em meio analógico e digital - suscitou a pergunta: como conduzir a expressão por caminhos inesperados, abrindo possibilidades criativas novas, sem ceder aos automatismos prescritos na linguagem dos softwares de manipulação de imagens? E ainda, em que medida seria possível estabelecer algum contato físico - com materiais, pessoas, espaços - no processo de elaboração e apresentação da obra neste contexto imaterial? 
Fluxos 


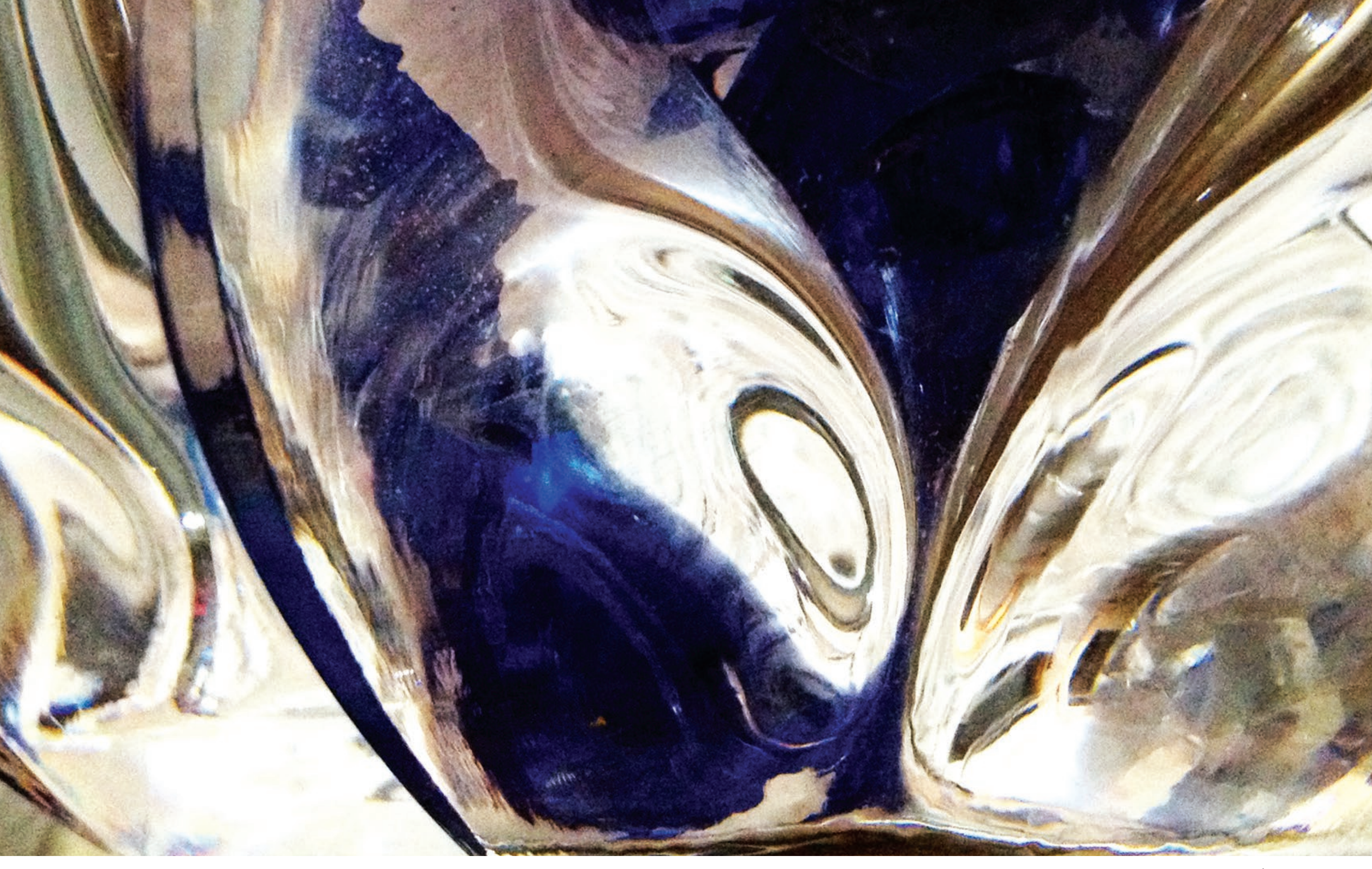




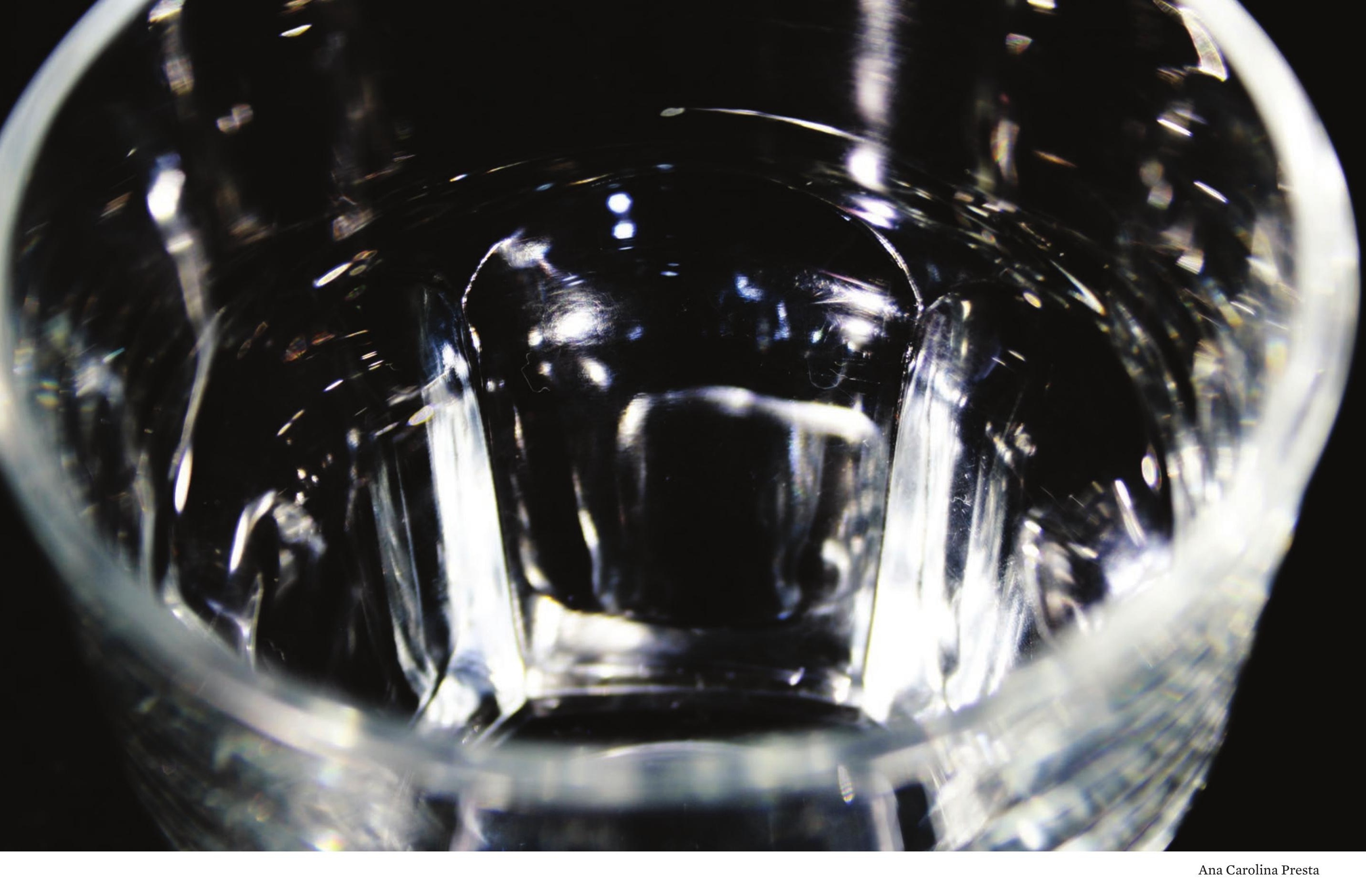




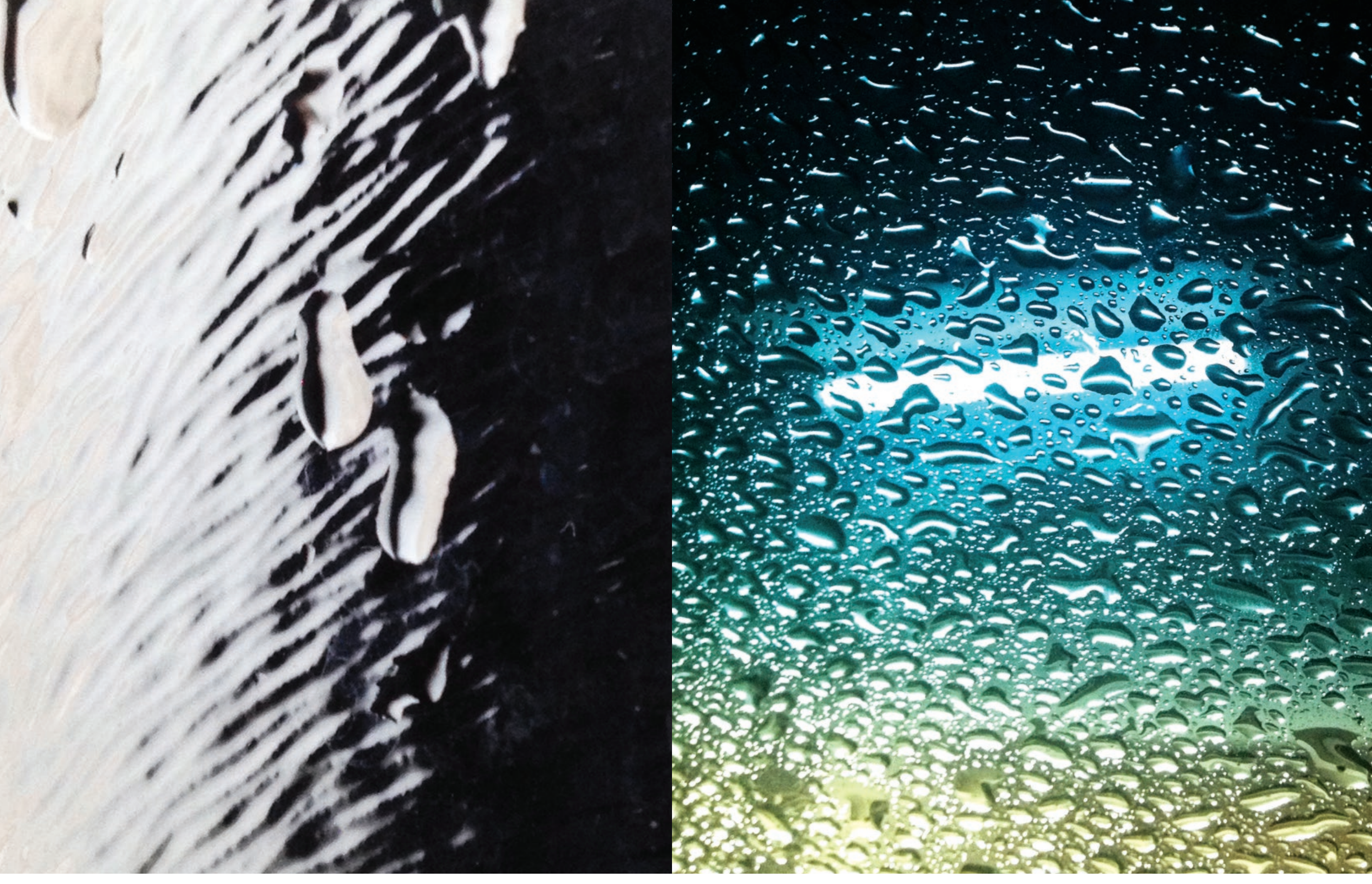




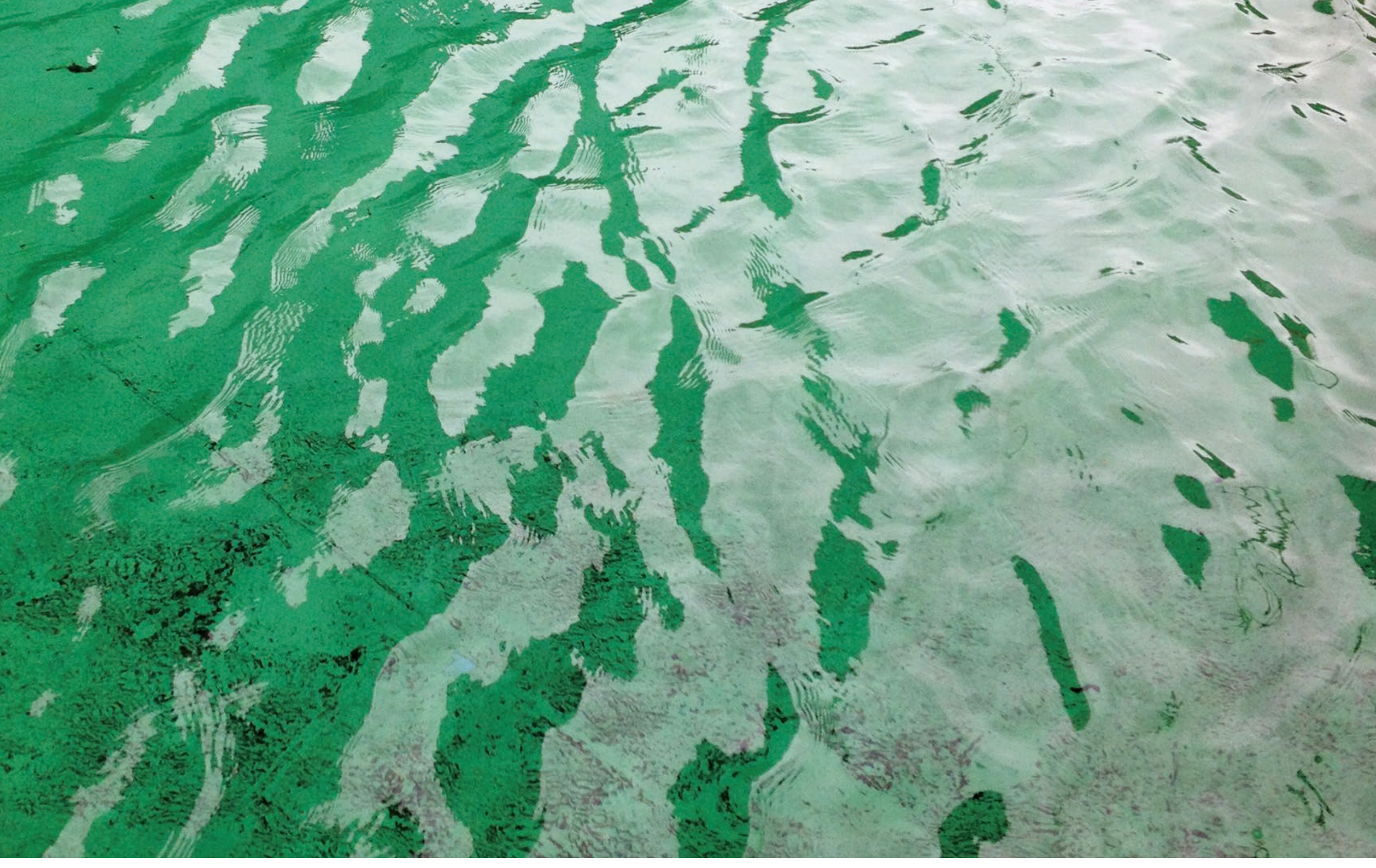



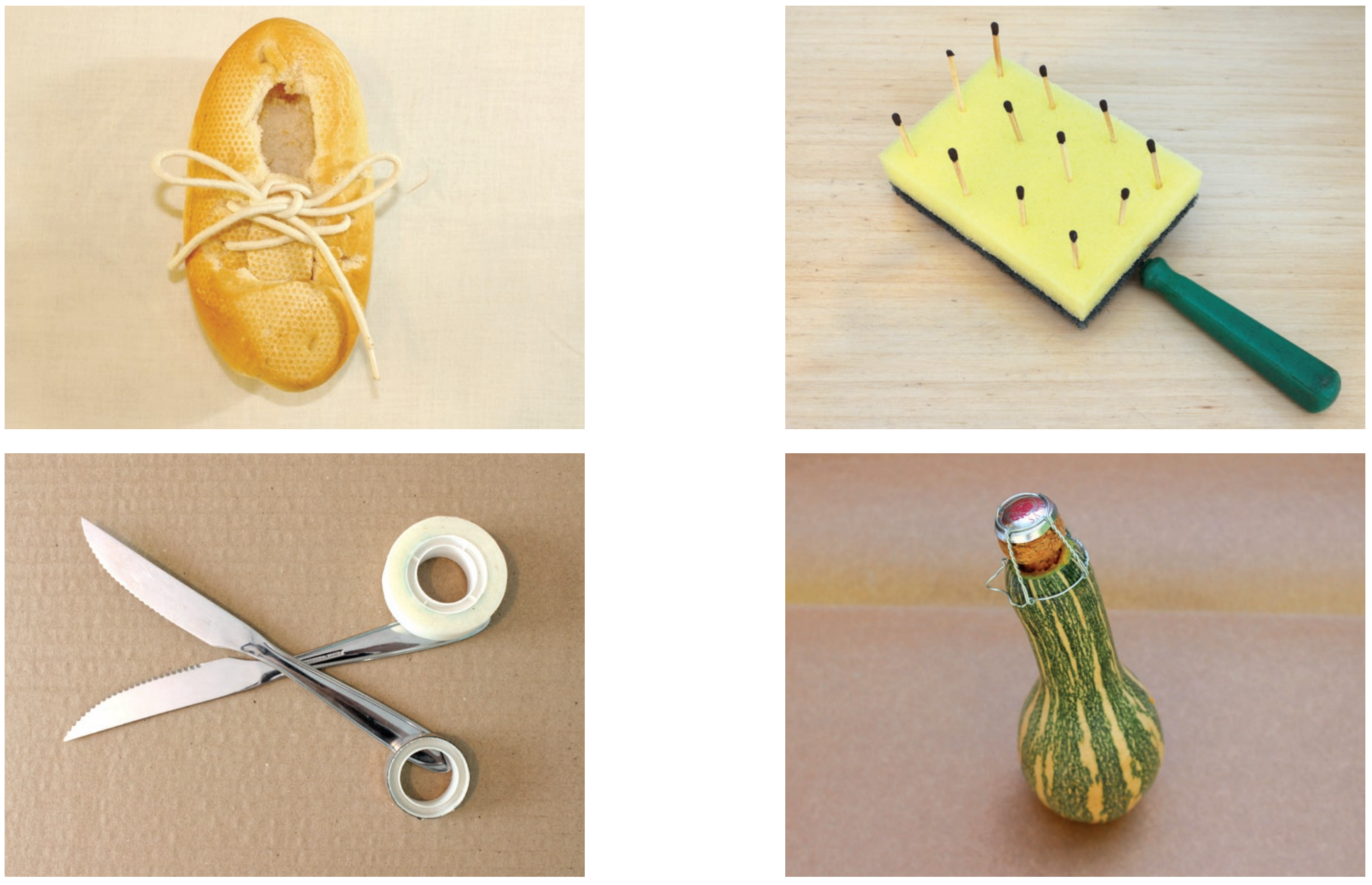


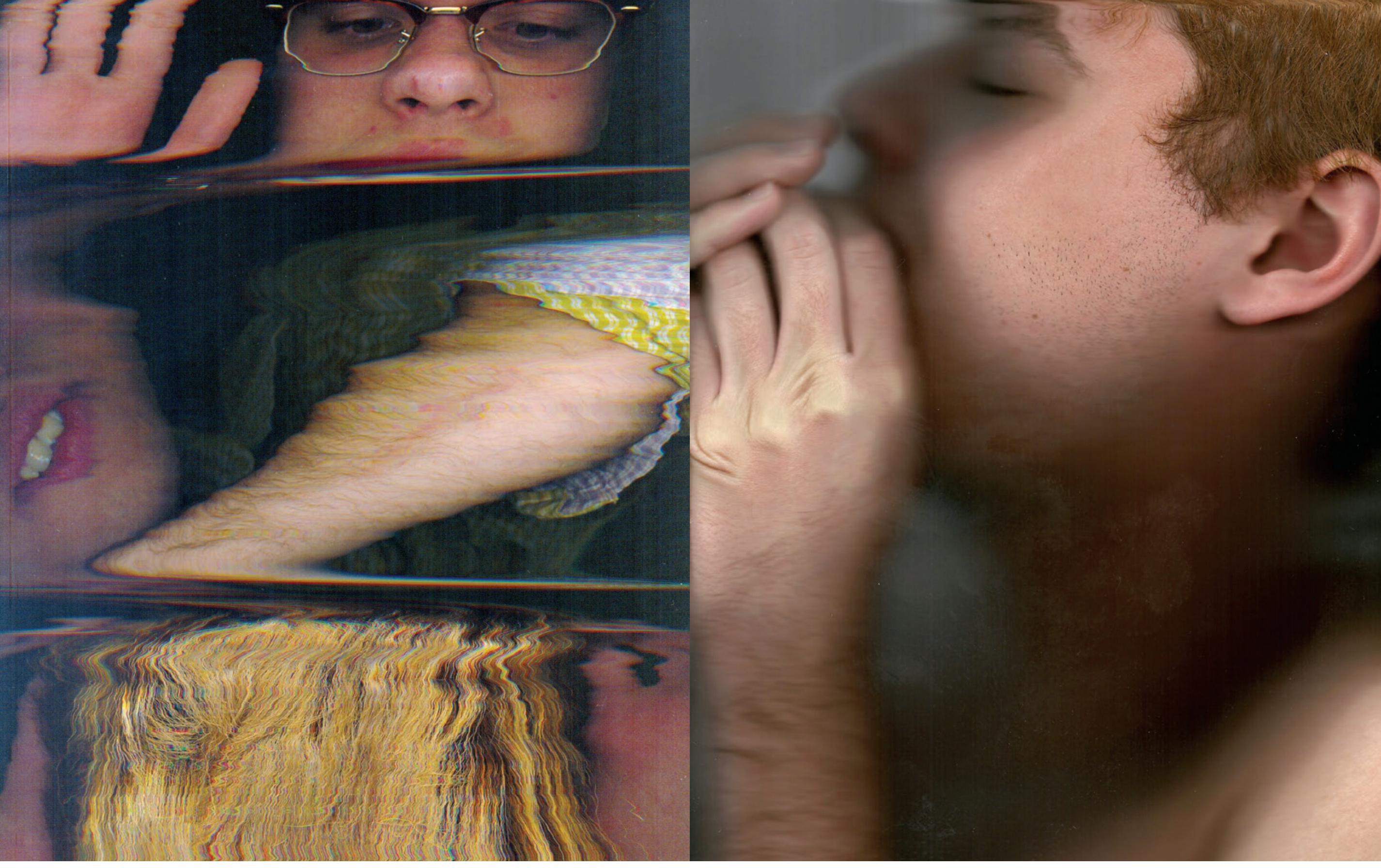





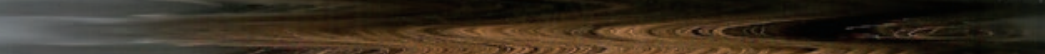

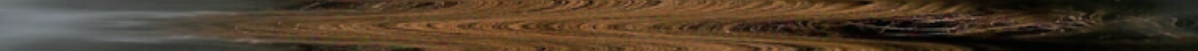
-

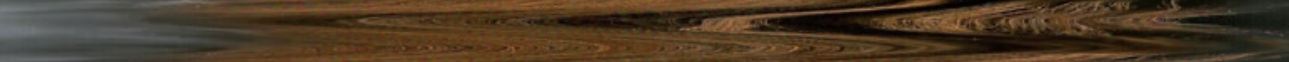

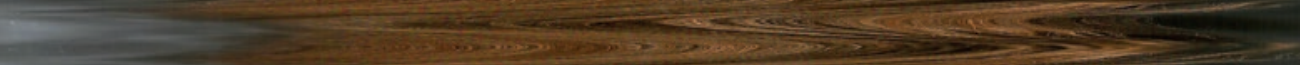

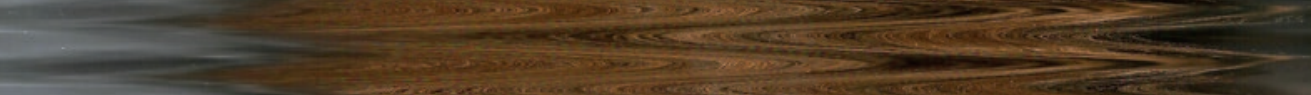

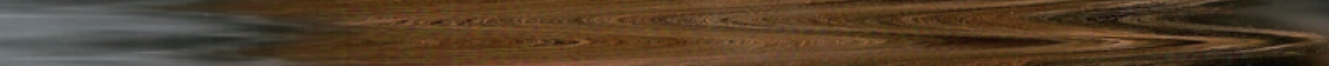

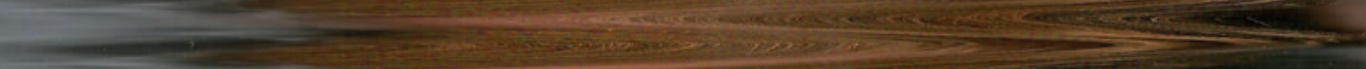
W

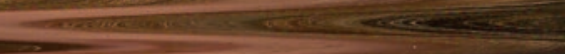

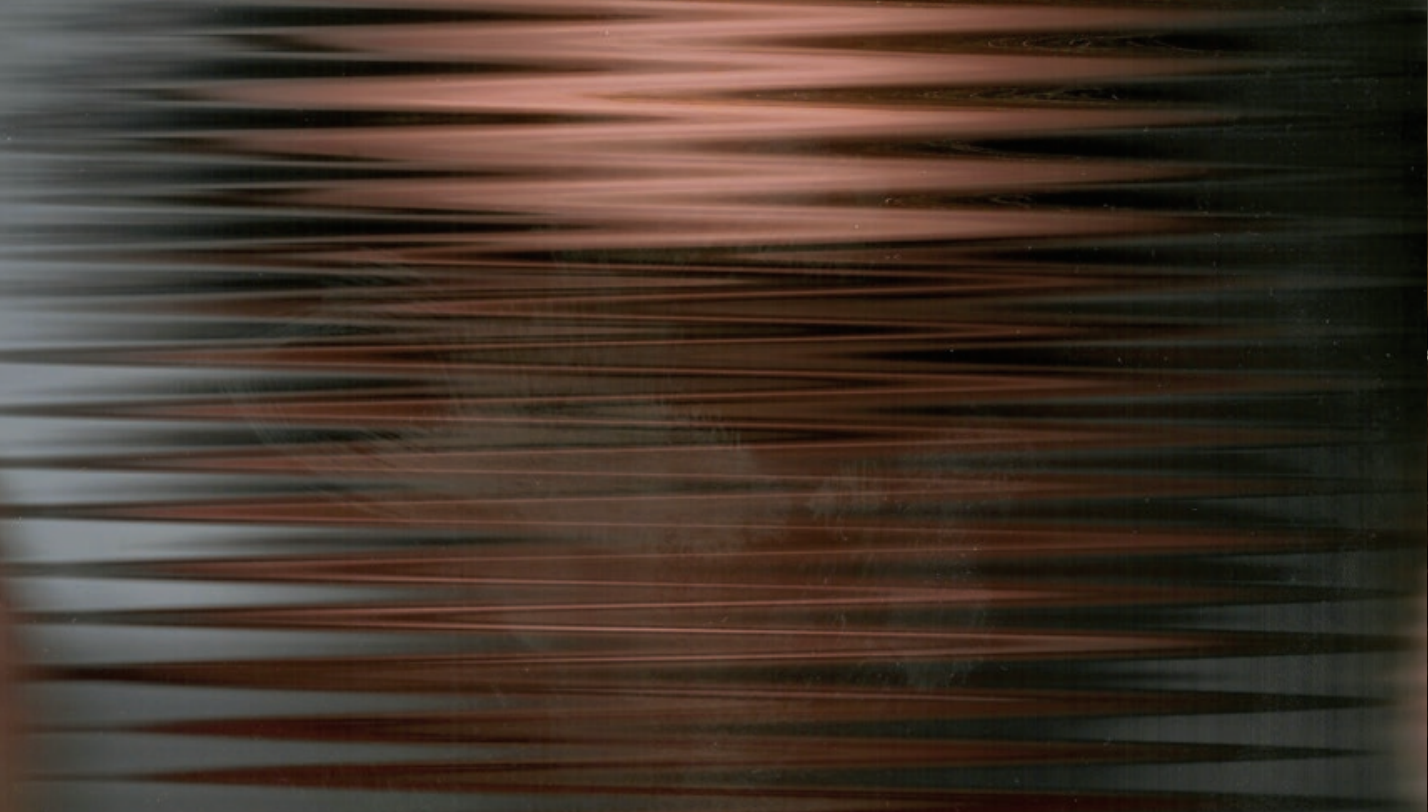



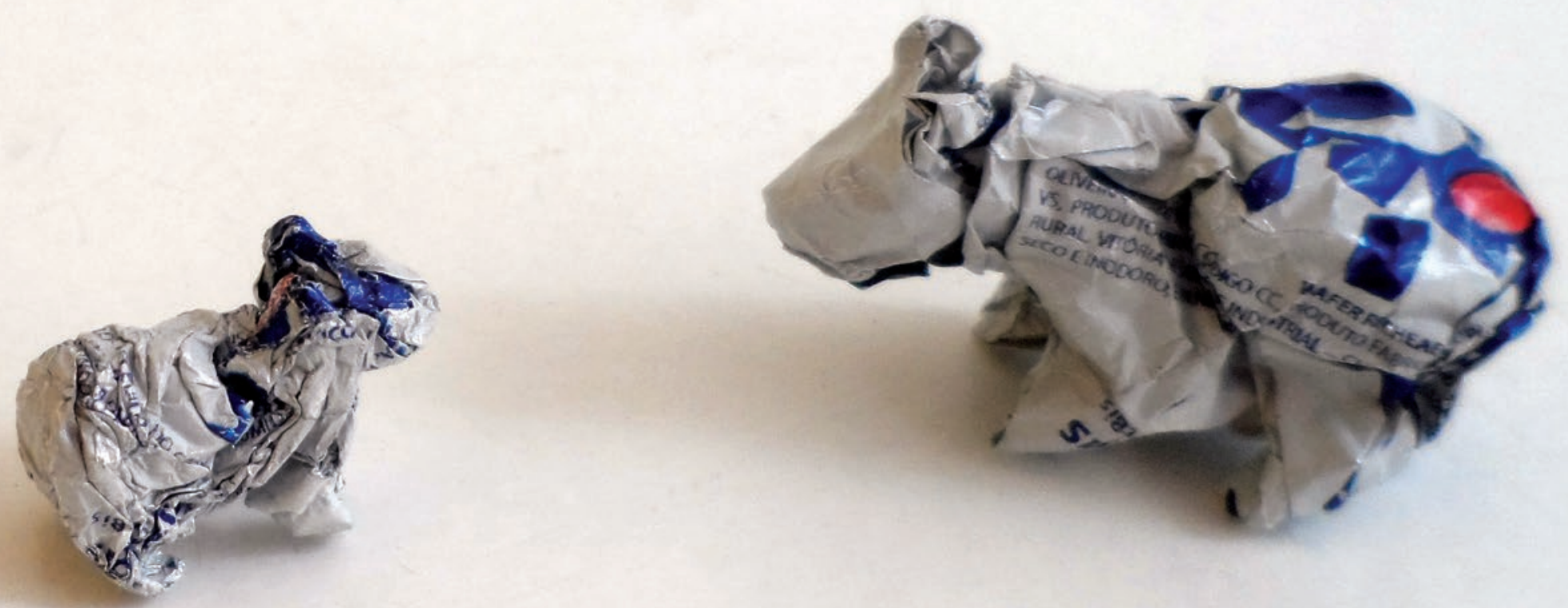


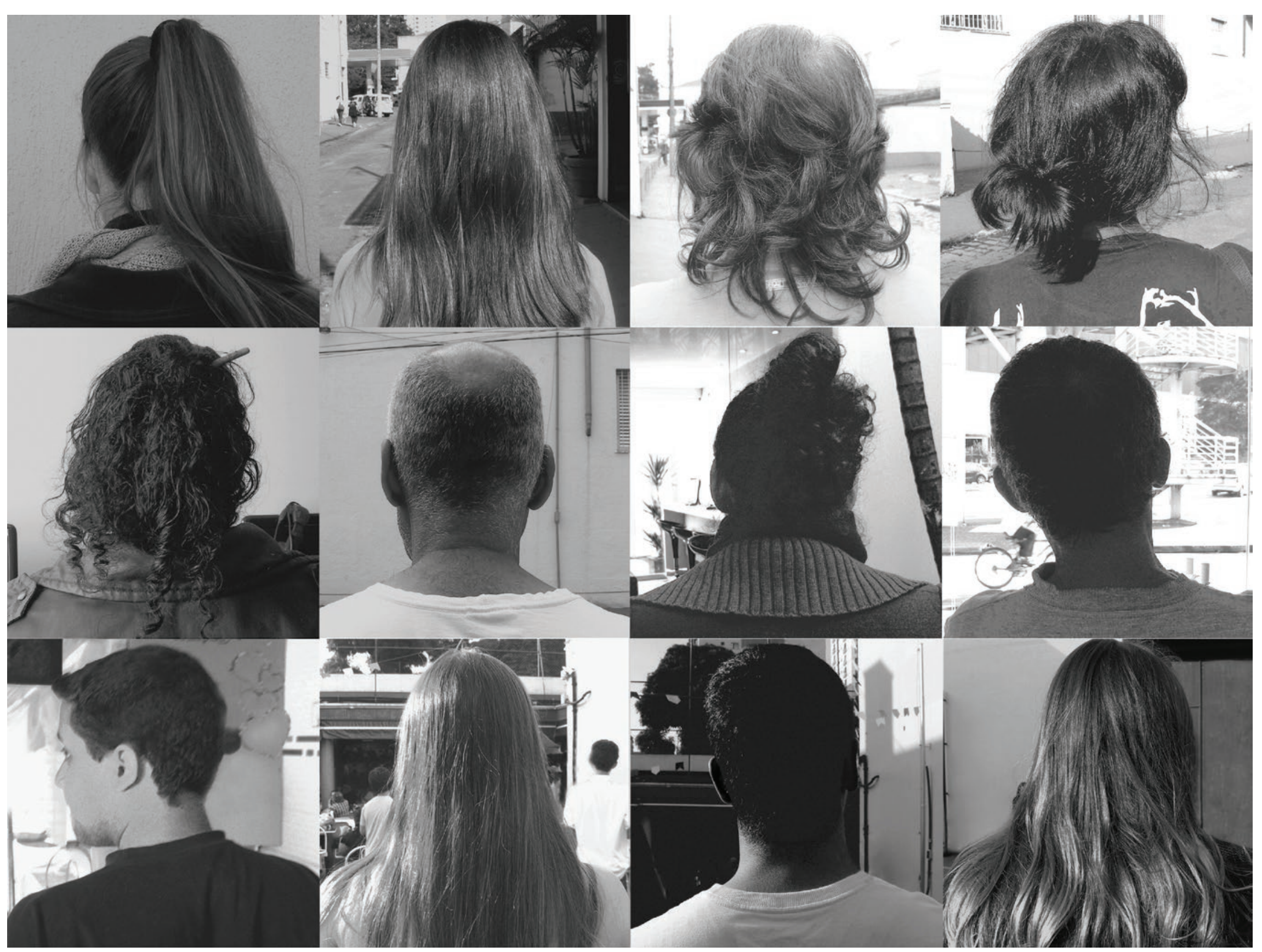




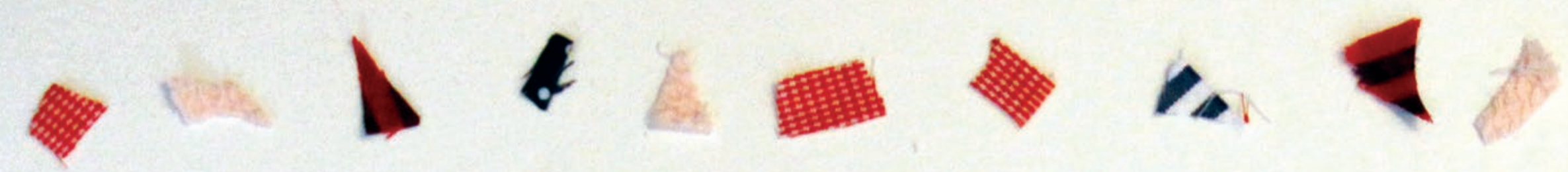
$07-1-D_{0}<1$ $114-4<\leqslant 079$

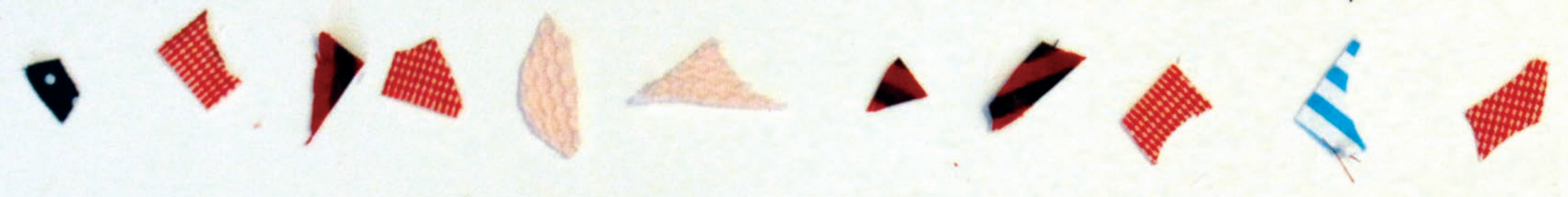

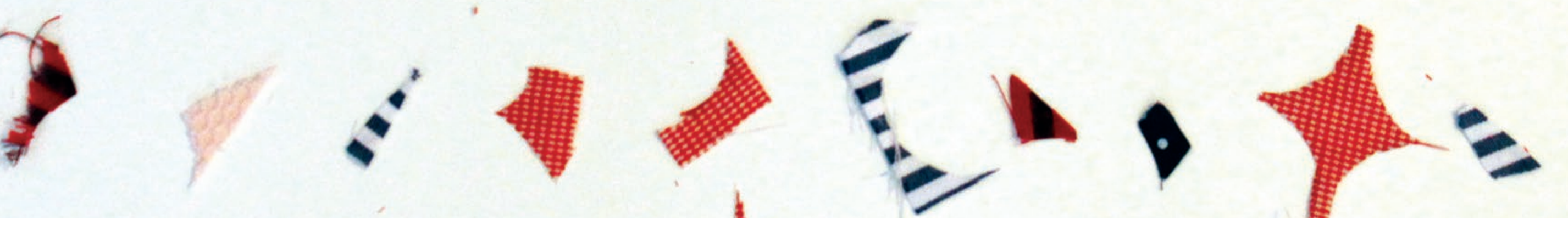





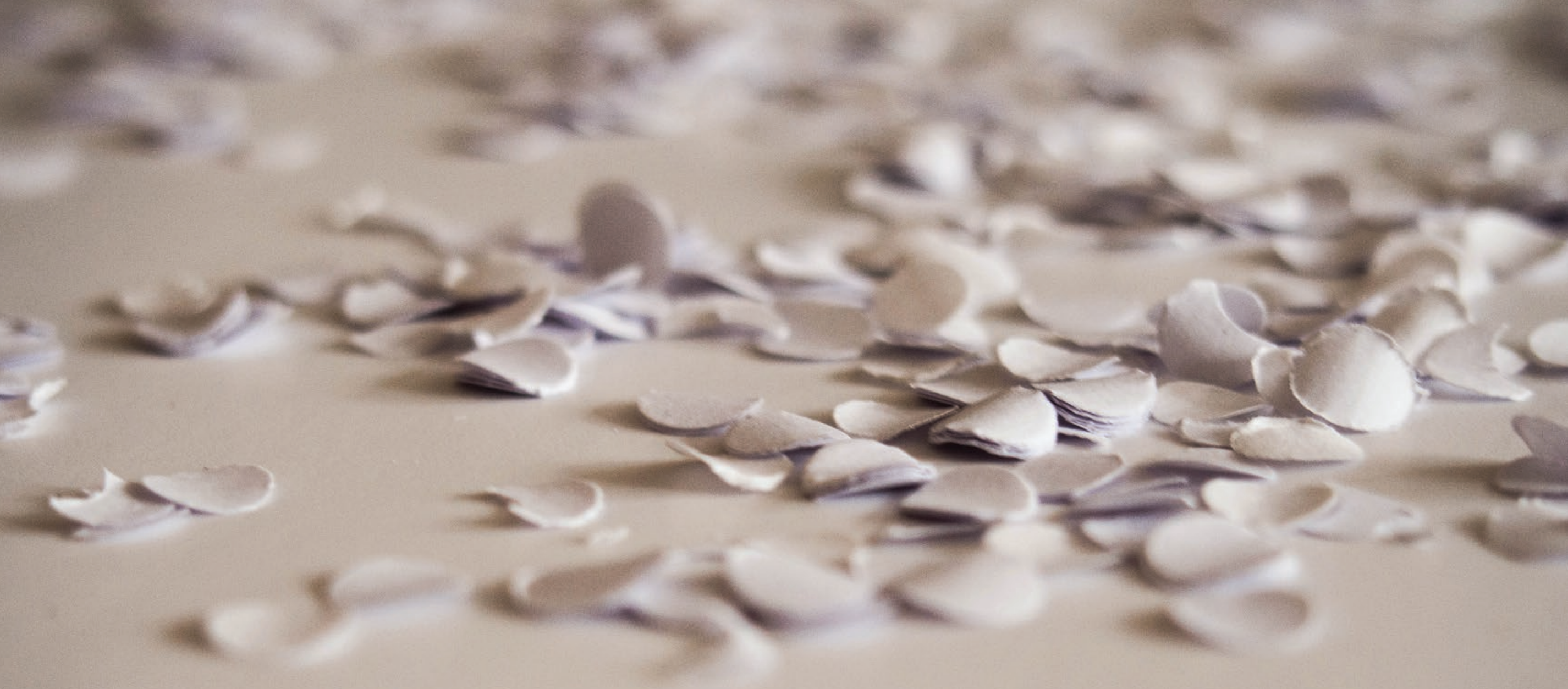



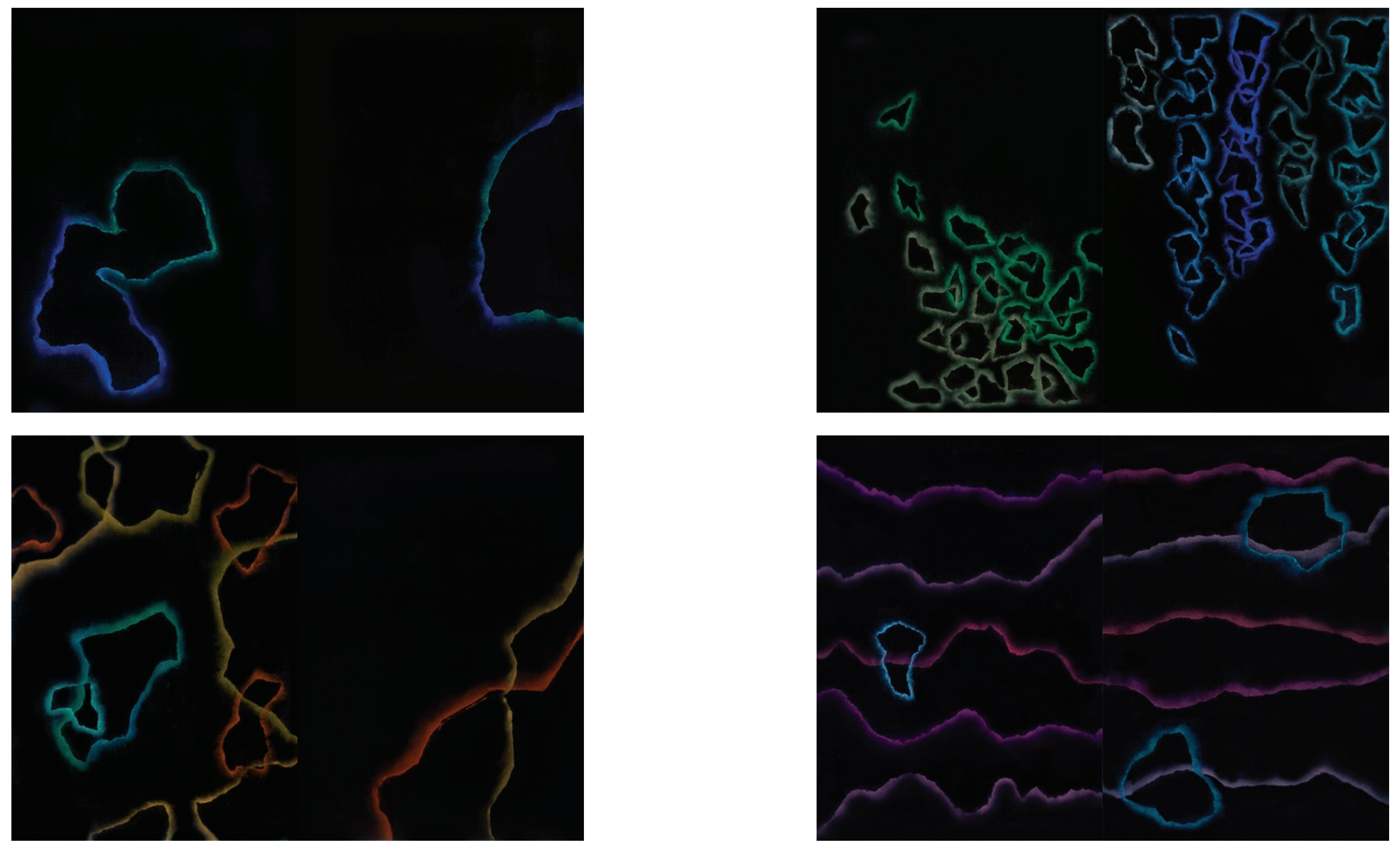

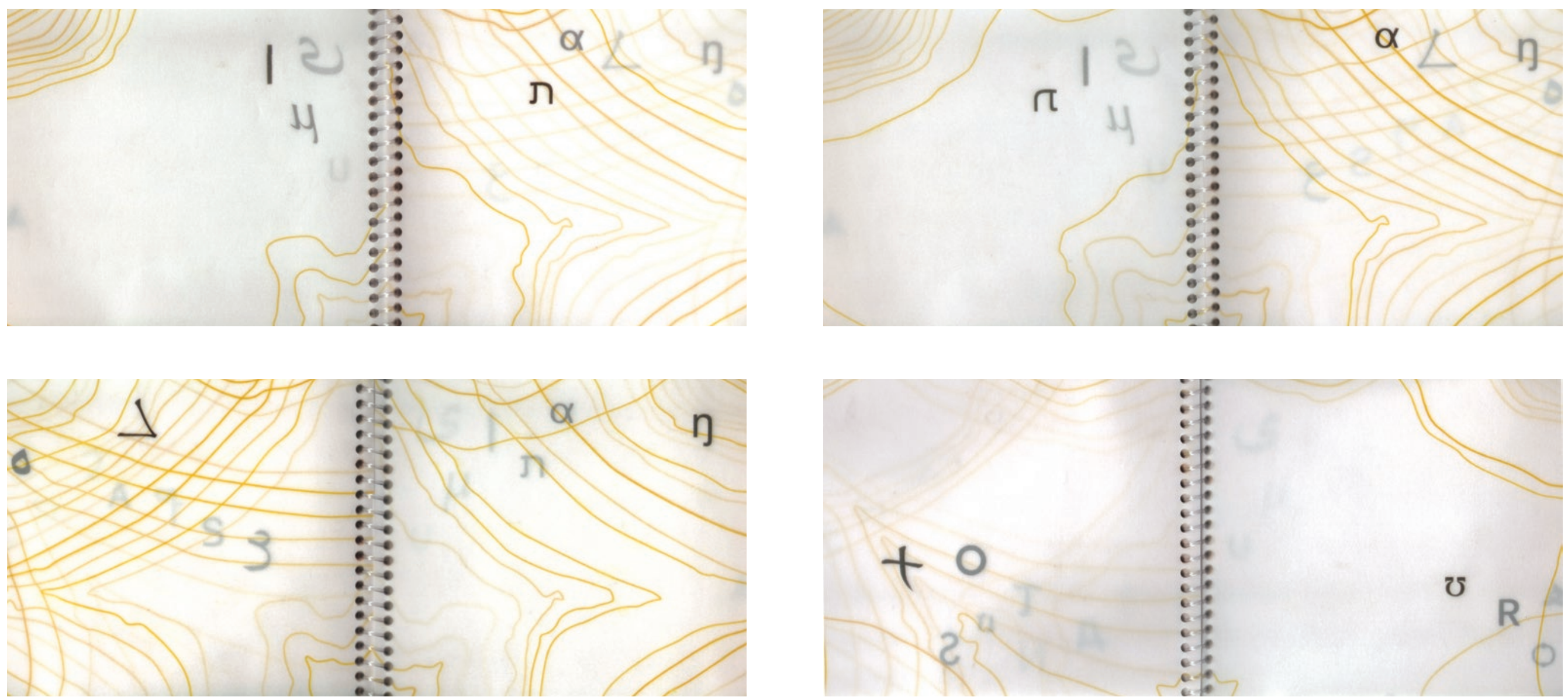


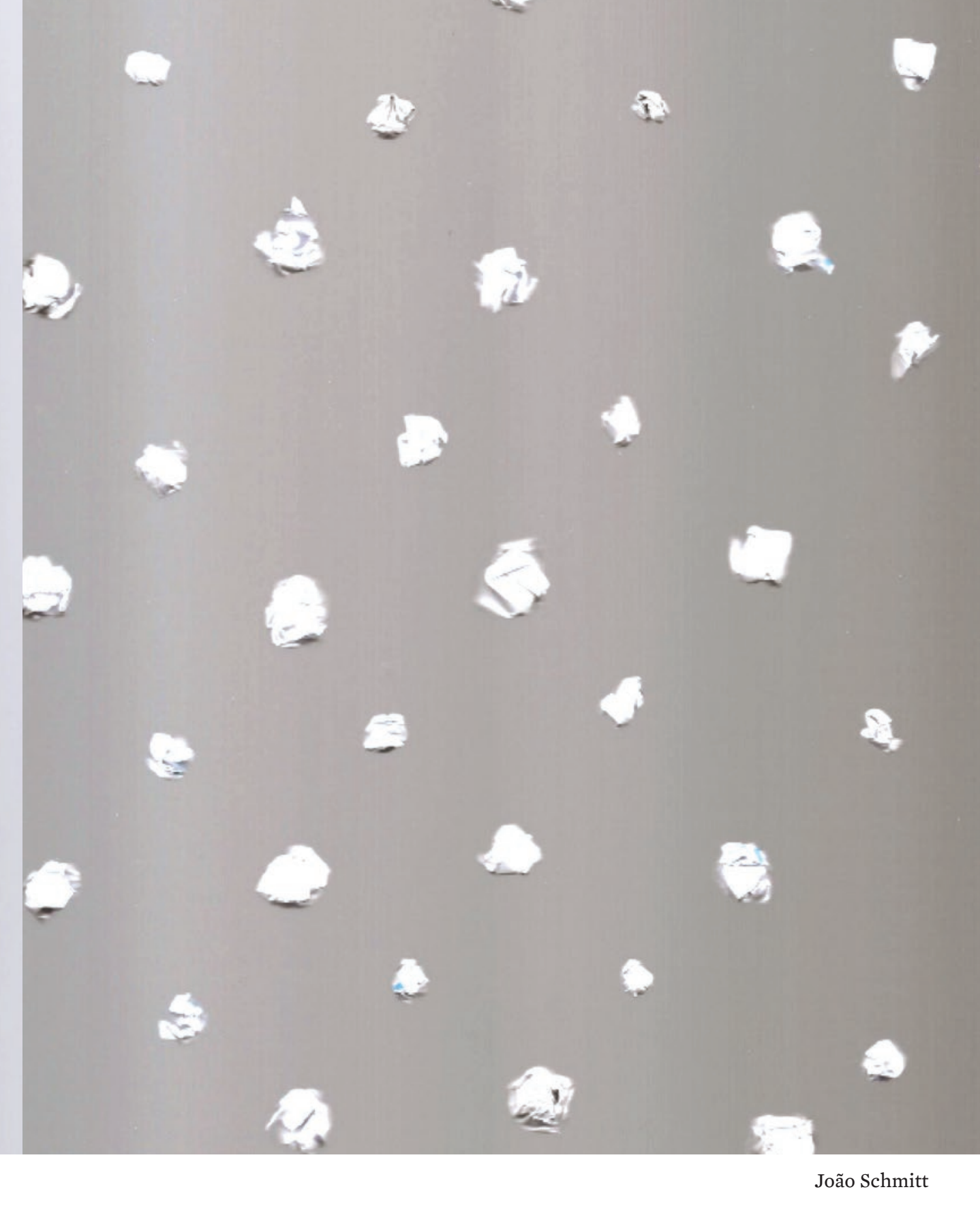




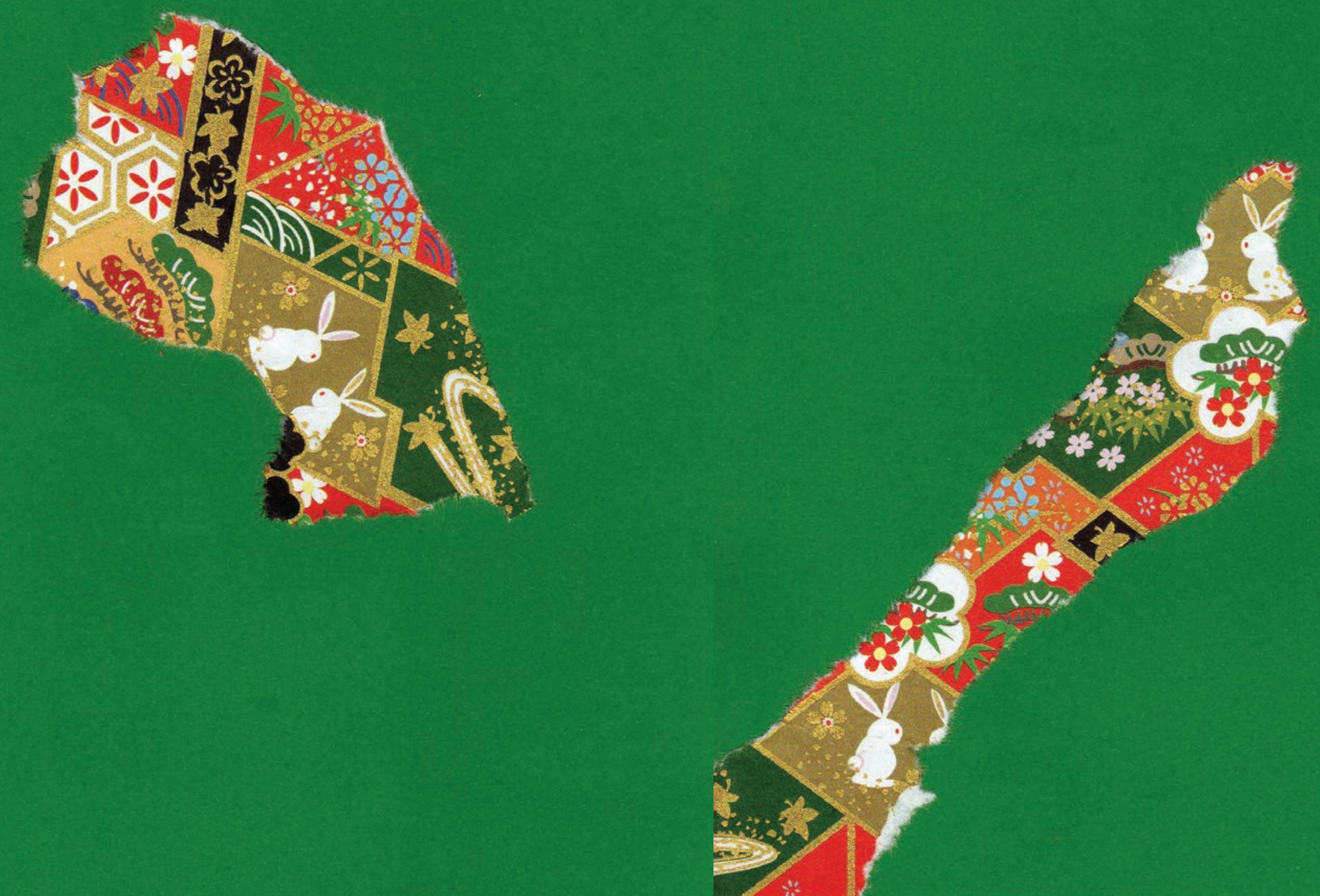

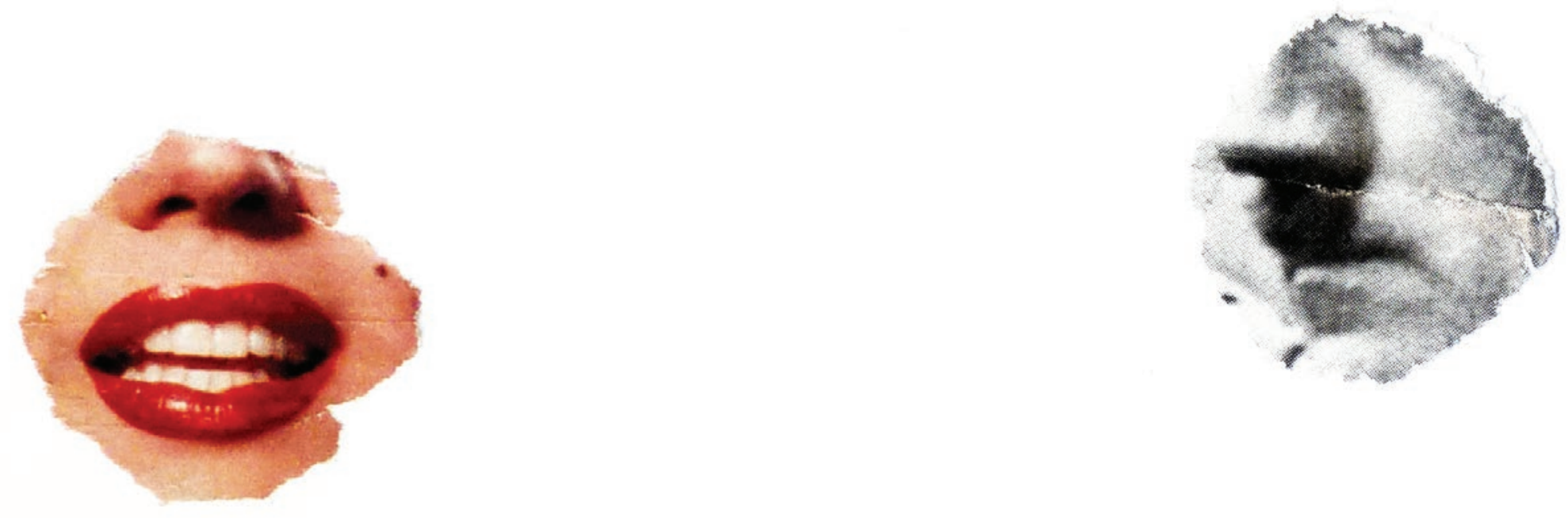

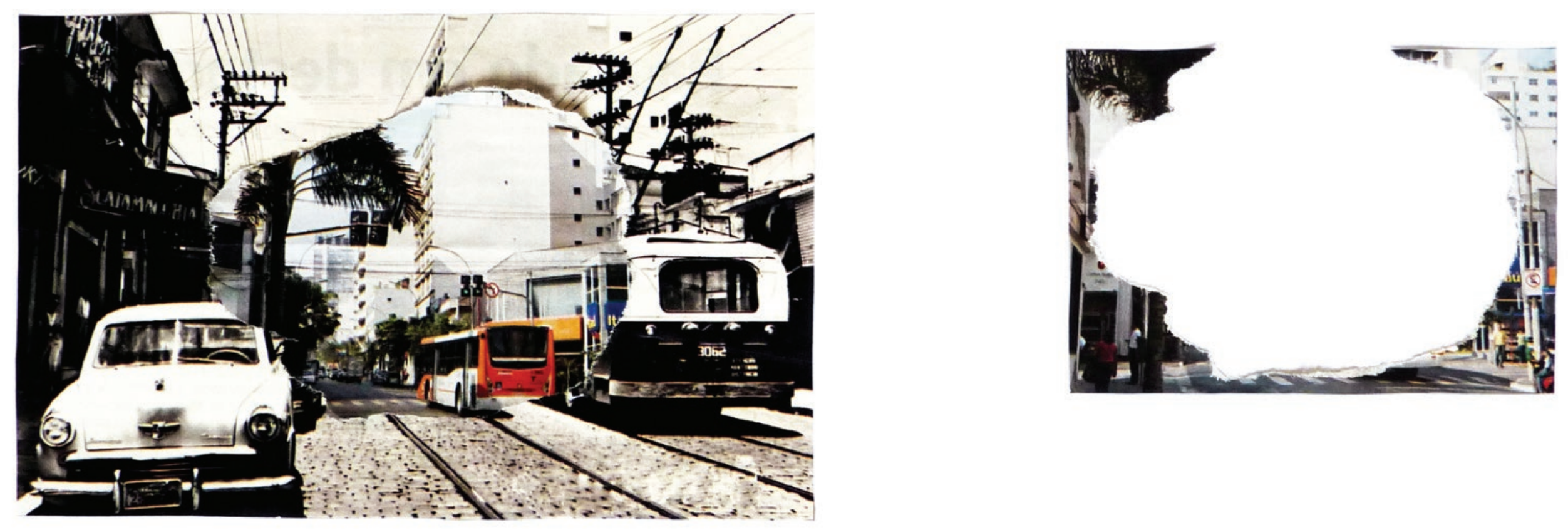


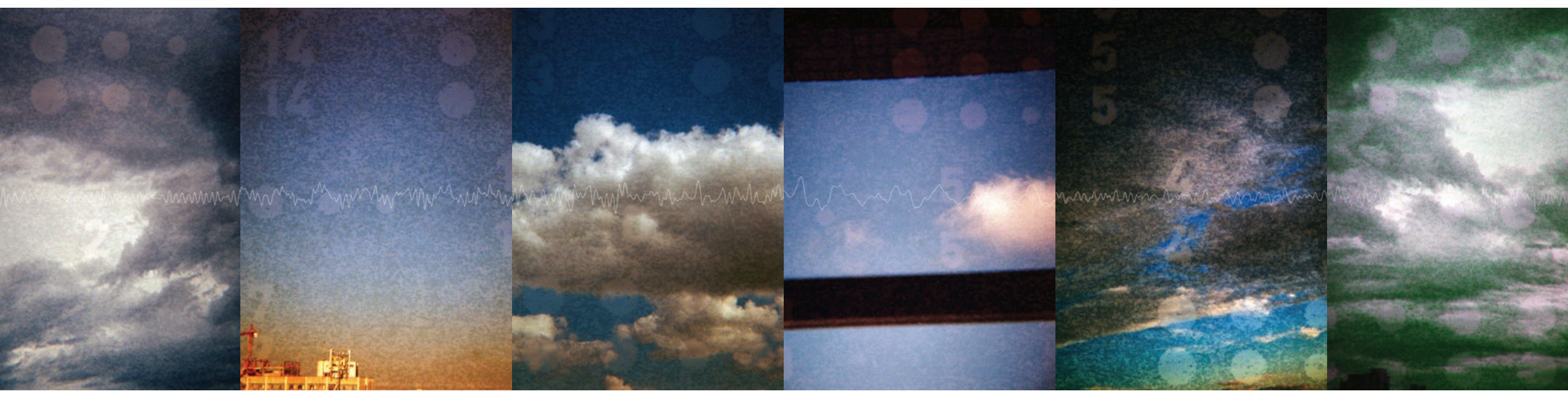



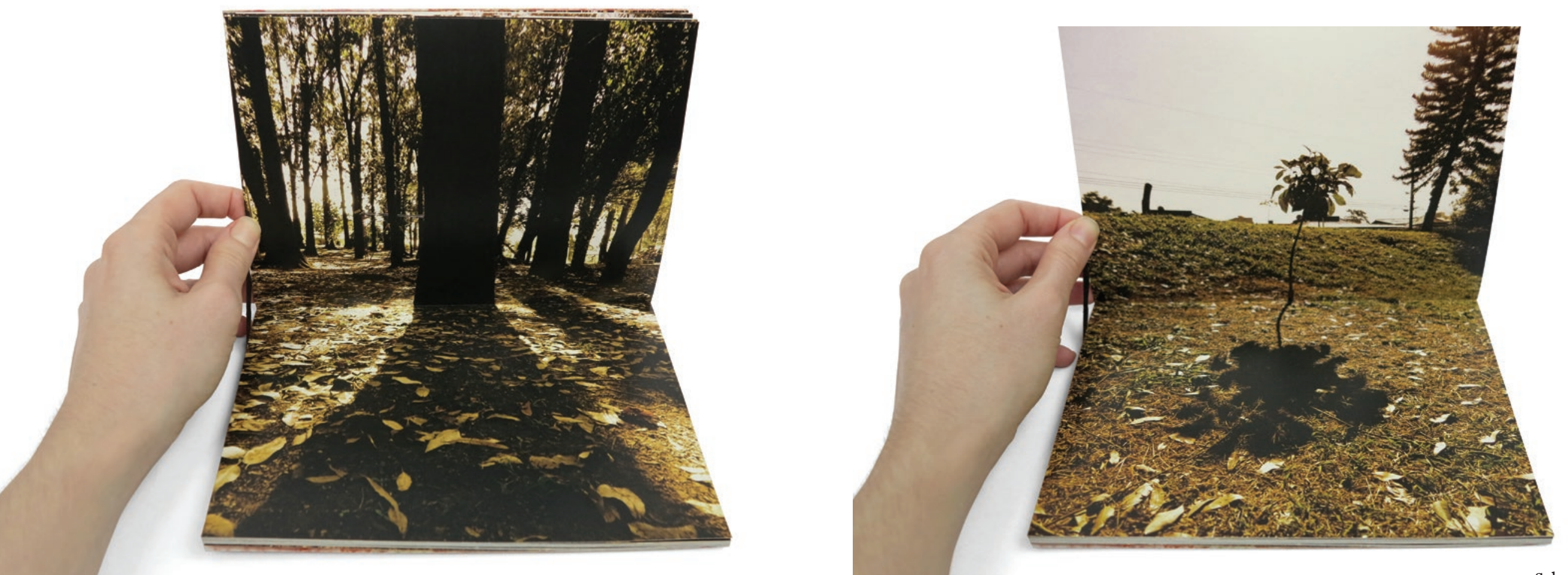

Sabrina Duarte 


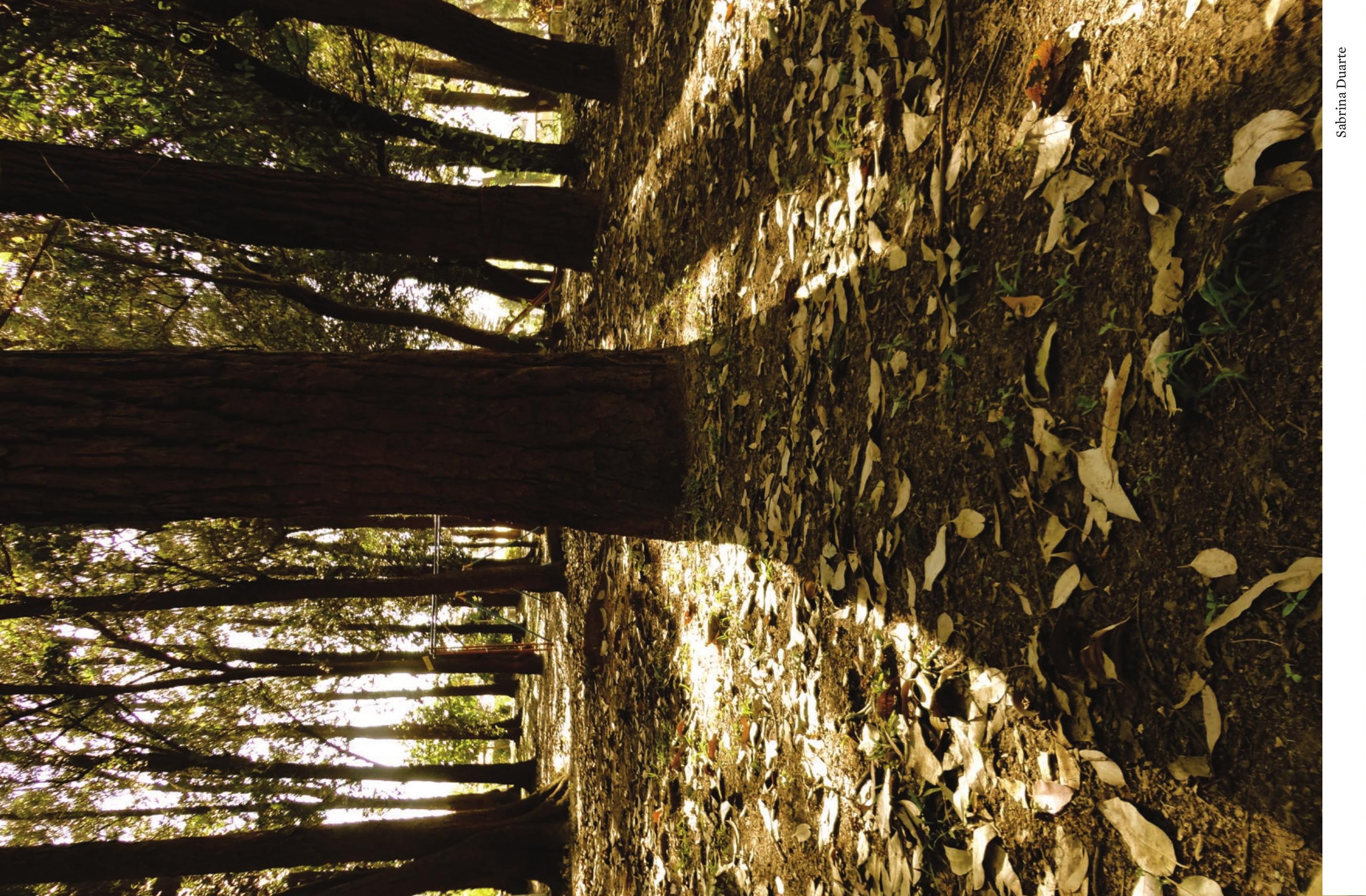




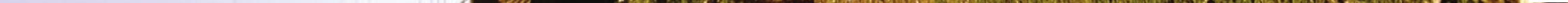




\section{O tempo da tese: pesquisa como vivência}

Ao vivenciar a produção artística em simultaneidade com a experiência didática, constato a necessidade de refletir sobre os fluxos existentes entre o fazer e o ensinar a fazer, no âmbito dos processos de criação da visualidade. É possível ensinar a criar imagens? Como ensinar?

Que a arte na realidade não se aprende. Existe, é certo, dentro da arte, um elemento, o material, que é necessário pôr em ação, mover, pra que a obra de arte se faça. [...] Mas nos processos de movimentar o material, a arte se confunde quase inteiramente com o artesanato. Pelo menos naquilo que se aprende. [...] Todo artista tem de ser ao mesmo tempo artesão. [...]

$\mathrm{O}$ artesanato, os segredos, os caprichos, as exigências do material, isto é assunto ensinável [...].

$\mathrm{O}$ artesanato é a parte da técnica que se pode ensinar. Mas há uma parte da técnica de arte que é, por assim dizer, a objetivação, a concretização de uma verdade interior do artista. Esta parte da técnica obedece a segredos, caprichos e imperativos do ser subjetivo, em tudo que ele é, como indivíduo e como ser social. Isto não se ensina e reproduzir é imitação. (ANDRADE, 1955, s.p.).

O desafio de ensinar me anima a pesquisar, que me anima a ensinar. Circuito contínuo de vivência e informação sempre em movimento: conhecer, perceber, sentir, aprender, ensinar, trocar, tornar a aprender.

Vivi uma experiência de ensino, concomitante à realização desta tese, particularmente estimulante, ao ministrar a disciplina Linguagens Visuais para os alunos do primeiro semestre do curso de Design da Faculdade de Arquitetura e Urbanismo da Univer- sidade de São Paulo (FAU-USP). Acompanhei cada aluno em seu caminho subjetivo rumo à criação de uma linguagem, ao mesmo tempo em que percorria meu próprio trajeto criativo e reflexivo na realização da tese. A simultaneidade dos nossos fazeres nos aproximou. O contato vivo com os alunos colocou-me em um estado permanente de desassossego. Durante o período de elaboração da tese, a atenção e a sensibilidade potencializam-se. Entro, a todo momento, em estado de investigação, movida pela curiosidade e pelo faro, à caça de descobertas. Nesse tempo auspicioso, os fatos vivenciados ganham tonalidades e relevos especiais.

Apesar de reconhecer a convergência extraordinária entre o fazer artístico, o ensino e a pesquisa possibilitada pela atuação como professora na FAU durante o doutorado, a proposta que elaborei para a disciplina Linguagens Visuais não tinha, a priori, nenhuma relação com o desenrolar da pesquisa. Ou seja, naquele momento inicial, não estabeleci uma metodologia a ser cumprida visando registrar a experiência de ensino na tese, tampouco me comprometi a analisar os processos e produtos dos alunos. No final do semestre, constatei que aquela experiência didática somada aos resultados alcançados pelos alunos estavam estreitamente vinculados com os pensamentos e ações presentes na concepção do Corpo de provas.

\section{Um sinal no espaço}

Sem deixar de considerar os objetivos pedagógicos da disciplina Linguagens Visuais, imaginei um exercício que interessasse aos alunos tanto quanto eu me interessaria em fazê-lo. Logo no início do curso, indiquei a leitura do conto "Um sinal no espaço", do livro As cosmicômicas, de Ítalo Calvino. Depois da leitura, cada aluno 
prosseguiria com a criação livre de imagens que, por fim, seriam editadas na forma de um pequeno livro.

Em As cosmicômicas, Calvino busca estímulos na ciência para fazer literatura: inicia cada conto com um enunciado científico a respeito da formação do cosmos e, a partir das epígrafes, desenrola narrativas cômicas, fantásticas, focadas nas relações humanas. Calvino deixa à mostra pistas sobre a construção de seu projeto literário, lembrando-nos de que a capacidade imaginativa é requisitada para dar visibilidade tanto à ciência quanto à literatura.

Imaginei que o contato com o conto "Um sinal no espaço" serviria como detonador de poéticas que dariam início ao trabalho de criação visual, levando a pensamentos associativos sobre sinais, gestos, desenho, traço, indivíduos, espaços etc.

A situação era, portanto, esta: o sinal servia para assinalar um ponto, mas ao mesmo tempo assinalava que ali havia um sinal, algo ainda mais importante porquanto pontos havia muitos enquanto sina só havia aquele, e ao mesmo tempo o sinal era o meu sinal, o sinal de mim, porque era o único sinal que eu já havia feito e eu o único desde sempre a fazer sinais. (CALVINO, 1992, p. 37).

Se cada um de nós é uma combinatória de experiências, informações, leituras, imaginações (CALVINO, 1990), o professor deixa-se conhecer pelos alunos ao emitir os sinais que configuram, em primeiro lugar, o seu repertório. Ao mostrar-se, aproxima-se. Nessa experiência de ensino, a opção por Calvino e por aquele conto surtiu um efeito mais potente que aquele que eu havia previsto: a voz de um autor tão vivo no meu rol de afetividades estava agora falando diretamente aos alunos. Eles se entusiasmaram pela proposta do trabalho ao relacionar os sinais no espaço cósmico narrados por Calvino com a multiplicidade de signos visuais que podem ser criados por designers.

Logo após a leitura do texto, seguida de discussão sobre ele, ainda na primeira ou segunda aula do curso, realizei um exercício livre de desenho: grafar um sinal ou vários sinais no espaço da folha de papel em branco. Mesmo tratando-se de alunos de um curso de Design, recém-aprovados em uma prova de habilidades específicas de desenho após meses de preparo, percebi que alguns se sentiram intimidados pela proposta, como se estivessem novamente sendo julgados sobre seus erros e acertos. Fiz o possível para dissipar a expectativa por certos resultados. Acatei e sugeri que acatassem toda expressão visual que surgisse nos desenhos, argumentando que os resultados imprevistos eram os mais interessantes. Alguns alunos pareciam redescobrir o sentido de gestos elementares como desenhar, rasgar um papel e brincar com os pedaços, que provavelmente teriam sido abandonados depois da alfabetização (DWORECKI, 1998). Aquela era a primeira oportunidade de começar a conhecer seus gestos, histórias, intenções plásticas e repertório.

$\mathrm{Na}$ apreciação coletiva dos desenhos realizados, vários alunos relataram dificuldades de toda ordem, como: não saber por onde começar, não ter nenhuma ideia, não gostar dos próprios desenhos, sentir-se incapaz de realizar o exercício.

Logo que chega, o aluno tem impregnada em si a atitude escolar, punitiva e medíocre, de que o que vale é o acerto, julgando o erro motivo de execração, falência e insucesso. (DWORECKI, 1998, p. 120).

A qualquer momento o aluno é capaz de expressar-se. Desde sua primeira aula. Esta é a matéria-prima do início de um processo: o professor, admitindo a capacidade do aluno, toma sua primeiríssima expressão plástica como ponto de partida; não fornece comparações qualitativas [...]. (DWORECKI, 1998, p. 127). 
Propus, em seguida, uma inversão do vetor perceptivo. Em vez de expressar figuras através do desenho, sugeri a coleta de impressões sobre os sinais e espaços que observassem no dia a dia. Recomendei descrevê-los em uma lista de palavras, registrá-los através de desenhos ou fotografias. Insisti na abertura para todas as interpretações possíveis, na atenção ${ }^{12}$ sobre olhar, intenção e percepção - lembrando que perceber não é um ato passivo.

[...] A percepção é um ato de saída da energia para receber, e não de retenção da energia. Para nos impregnarmos de uma matéria, primeiro temos de mergulhar nela. Quando somos apenas passivos diante de uma cena, ela nos domina e, por falta de atividade de resposta, não percebemos aquilo que nos pressiona. Temos de reunir energia e colocá-la em um tom receptivo para absorver. (DEWEY, 2010, p. 136)

Percebe-se a partir do que se sabe, num ato de ampliar o já sabido. Essa ampliação tem, na aprendizagem, um instrumento que oferece o caráter dinâmico da percepção, que se planta nas situações, com espaço e tempo finitos, e vai ao encontro da história, do universo e da geografia corporal daquele que a empreita. É fator que devolve a sensação de estar na história e no universo, que re-liga esses conjuntos. (DWORECKI, 1998, p. 115).
Nas aulas seguintes, os alunos começaram a trazer os registros de seus olhares sobre os sinais e espaços imaginados ${ }^{13}$ ou visitados - o cosmos, árvores em um parque, reflexos de luz em objetos, sombras em um papel amassado, uma janela para o céu, o espaço do corpo, o espaço da página etc. As imagens trazidas pelos alunos eram inesperadas e surpreendentes - como as do aluno que posicionou o rosto sobre o escâner e registrou diversas poses de si, com uma atitude de liberdade e engajamento que considerei corajosa. Cada aluno elegeu procedimentos, materiais e técnicas livremente: desenho com nanquim, aquarela, giz pastel, colagem, fotografia, escaneamento... Vários optaram pela fotografia, provavelmente pela facilidade e intimidade com esse meio, já incorporado em seus cotidianos. Enquanto na linguagem do desenho muitos alunos buscam a semelhança com o real - tomando como padrão exemplos provenientes da história da arte, de histórias em quadrinhos, desenhos animados, jogos eletrônicos etc. -, o que acaba resultando em estereotipias, o uso da fotografia, por outro lado, liberta-os da busca por semelhanças, pois o que o aparelho fotográfico capta é justamente uma parte do mundo visível.

No percurso criativo dos alunos, assim como no meu, constato que a opção pela fotografia confere leveza ao processo de trabalho: uma vez com uma câmera em mãos, a fotografia digital não impõe limites de custo ou espaço físico; a execução da imagem é automática, imediata, não há fabricação manual; em suma, é um trabalho mais mental que corporal, beneficia o pensamento e a formulação de ideias.

13 "O espaço compreendido pela imaginação não pode ficar sendo o espaço indiferente abandonado à medida e reflexão do geômetra. É vivido. E é vivido não em sua positividade, mas com todas as parcialidades da imaginação" (BACHELARD, 2008, p. 196).
12 "A atenção impregna todos os momentos e procedimentos do ato de figurar A atenção decorre do interesse, que se deseja continuamente avivado pelos estímulos. Sua presença é tão fundamental na atividade artística quanto no processo de aprendizagem" (DWORECKI, 1998, p. 194). 
[...] A manipulação do aparelho é gesto técnico, isto é, gesto que articula conceitos. O aparelho obriga o fotógrafo a transcodificar sua intenção em conceitos, antes de poder transcodificá-la em imagens. Em fotografia, não pode haver ingenuidade. Nem mesmo turistas ou crianças fotografam ingenuamente. Agem conceitualmente, porque tecnicamente. Toda intenção estética, política ou epistemológica deve, necessariamente, passar pelo crivo da conceituação, antes de resultar em imagem.

O aparelho foi programado para isto. Fotografias são imagens de conceitos, são conceitos transcodificados em cenas. (FLUSSER, 2011, p. 52-53).

Percebi, em conjunto com os alunos, que a fotografia pode ser mais que um recorte do real, quando deixa à mostra a intenção de quem a tirou, quando articula conceitos, quando o coeficiente artístico $^{14}$ da imagem ultrapassa o valor documental. Achei interessante a possibilidade de criar, temporariamente, outra realidade, fotografá-la e depois destruí-la, como ocorreu no trabalho de alunos

${ }^{14}$ Marcel Duchamp (1965) descreve o coeficiente artístico como sendo "o mecanismo subjetivo que produz a arte em estado bruto. [...]

No ato criador, o artista passa da intenção à realização, através de uma cadeia de reações totalmente subjetivas. Sua luta pela realização é uma série de esforços, sofrimentos, satisfações, recusas, decisões que também não podem e não devem ser totalmente conscientes, pelo menos no plano estético.

$O$ resultado deste conflito é uma diferença entre a intenção e a sua realização, uma diferença de que $o$ artista não tem consciência.

Por conseguinte, na cadeia de reações que acompanham o ato criador falta um elo. Esta falha que representa a inabilidade do artista em expressar integralmente a sua intenção; esta diferença entre o que quis realizar e o que na verdade realizou é o 'coeficiente artístico' pessoal contido na sua obra de arte.

Em outras palavras, o 'coeficiente artístico' pessoal é como que uma relação aritmética entre o que permanece inexpresso embora intencionado, e o que é expresso não intencionalmente. (DUCHAMP, Marcel. O ato criador, 1965. Disponível em: <http://www.scribd.com/doc/168777318/Duchamp>. Acesso em 30/09/2013). que montaram situações com objetos do cotidiano ou esculturas provisórias de papel e procederam com o registro fotográfico. Gosto dessa facilidade em montar e desmontar pequenas cenas efêmeras, brincar com a escala das coisas no jogo das distâncias, experimentar enquadramentos, modulações da luz, gradações cromáticas... tudo isso ao alcance de um clique. Percebi que os liames entre fotografia, pintura, cor e luz, presentes no meu raciocínio plástico, compareciam também nas imagens produzidas pelos alunos.

Notei, ainda, que o registro do cotidiano funciona como estratégia pedagógica eficaz, na medida em que suscita momentos de atenção poética, facilmente registráveis, integrando o exercício da sensibilidade ${ }^{15}$ no dia a dia.

[...] Quando o mundo não é mais acessível a não ser através de um sistema de midiatizações, que o modifica em espetáculo, quando um fluxo sempre crescente de imagens o encobre e substitui, quando o mundo está, assim, reduzido a uma abstração, a um signo, a uma mercadoria que circula e se troca, então, nessa situação (que é a que prevalece no Ocidente), fotografar o cotidiano pode surgir como um modo de reatar com o concreto, o tangível, o vivido, o uso. Isso talvez consista em defender os valores humanos da vida contra a predominância crescente do abstrato, do factício, do virtual, do alhures. Do superficial. (ROUILLÉ, 2009, p. 362).

15 “[...] a sensibilidade é uma porta de entrada das sensações. Representa uma abertura constante ao mundo e nos liga de modo imediato ao acontecer em torno de nós" (OSTROWER, 2010, p. 12). 
A despeito de todas as vantagens possibilitadas pela fotografia, ouvi de alguns alunos que lhes faltava o equipamento adequado ou o conhecimento técnico para tirar uma boa foto. Argumentei que o emprego correto da técnica não era o desafio maior a perseguir, mas sim o gesto ou intenção de quem fotografa ${ }^{16}$. A cada aula, eu devolvia uma observação, uma sugestão de como prosseguir. Mas o comentário crítico só era possível como resposta aos acontecimentos daquela semana, fossem eles avanços ou retrocessos.

Vivenciar a experiência, como respirar, é um ritmo de absorções e expulsões. Sua sucessão é pontuada e transformada em um ritmo pela existência de intervalos, períodos em que uma fase é cessada e uma outra é inicial e preparatória. William James fez uma comparação oportuna entre o curso de uma experiência consciente e os voos e pousos alternados de um pássaro. Os voos e pousos ligam-se intimamente uns aos outros; não são um punhado de alçamentos não relacionados, seguidos igualmente por alguns saltinhos não relacionados. Cada lugar de repouso, na experiência, é um vivenciar em que são absorvidas e incorporadas as consequências de atos anteriores, e, a menos que esses atos sejam de extremo capricho ou pura rotina, cada um traz em si um significado que foi extraído ou conservado. (DEWEY, 2010, p. 140).

16 “[...] A técnica jamais, em tempo algum, determinou isoladamente a forma de nossas ações; ela sempre forneceu os meios [...] a partir do momento em que o técnico superior cria não só um objeto mas uma forma, ele age como artista, isto é, como criador não apenas de conceitos ou de objetos mas de esquemas de pensamento" (FRANCASTEL, 1993, p. 3).
No decorrer do semestre, comecei a saber, gradativamente, que a vivência do ensino, as reflexões provocadas pelo encontro dos nossos caminhos criativos, o convívio e o aprendizado estavam compondo uma alquimia potente e transformadora. Sustentei tal estado de desassossego ao notar que acontecia algo novo, ainda impossível de ser nomeado. Mantive uma atitude experimental, tateante, porosa, sensível. Segui a intuição e alimentei a simpatia com o devir de cada encontro.

[...] a intuição é aquilo pelo qual entramos em contato com o outro em nós (o material, o vital, o social); nesse sentido, ela permanece uma relação de si para si, e não pode ser nada mais do que isso. Inversamente, a simpatia entra em relação com um outro, podemos até mesmo dizer que ela entra no interior desse outro projetando nele nossa interioridade, revelando nele uma direção, uma intenção, uma consciência - que são também os movimentos da nossa própria alteridade interior. (LAPOUJADE, 2013, p. 65-66).

\section{A sala de aula como heterotopia}

[...] As utopias são sítios sem lugar real. São sítios que têm uma relação analógica directa ou invertida com o espaço real da Sociedade. Apresentam a sociedade numa forma aperfeiçoada, ou totalmente virada ao contrário. Seja como for, as utopias são espaços fundamentalmente irreais.

Há também, provavelmente em todas as culturas, em todas as civilizações, espaços reais - espaços que existem e que são formados na própria fundação da sociedade - que são algo como contra-sítios, espécies de utopias realizadas nas quais todos os outros sítios reais dessa dada cultura podem ser encontrados, e nas quais são, simultaneamente, representados, contestados e invertidos. Este tipo de lugares 
está fora de todos os lugares, apesar de se poder obviamente apontar a sua posição geográfica na realidade. Devido a estes lugares serem totalmente diferentes de quaisquer outros sítios, que eles reflectem e discutem, chamá-los-ei, por contraste às utopias, heterotopias. (FOUCAULT, 1984, p. 46-49, tradução de Pedro Moura).

As heterotopias se produzem pela negação do instituído e pela ressignificação do marginal (no sentido de estar à margem). Do ponto de vista da emancipação, podemos pensar a heterotopia como espaço marginal, que engendra ações rebeldes - práticas que se materializam de forma diferenciada em lugares instituídos. Toda heterotopia engendra um acontecimento novo. (PÉREZ, 2007, p. 129).

Situações de contato humano são cada vez mais raras, dada a crescente migração de grande parte do convívio social para as redes virtuais. A sala de aula, modelo quase anacrônico, baseado na presença e na transmissão oral do conhecimento, ainda resiste como espaço de encontro, uma utopia situada em um lugar real. A aula é o evento que configura esse contralugar, dotado de um tempo próprio, onde é possível inventar novos modos de viver e conviver. No passo acelerado da contemporaneidade, em que tudo voa - homens, produtos, mercadorias, imagens e ideias (SANTOS, 2004) -, o contato ao vivo em uma situação de aprendizagem insere uma fratura no tempo e no espaço comum, convertendo-nos em um espaço-tempo da criação. Particulariza, sobretudo, a duração do momento vivenciado.
[...] somos apenas vibração, uma certa frequência de tom que dura, isso é a nossa própria essência. E é por aí que podemos nos abrir para outras realidades, entrar na sua perspectiva até onde seja possível ajustar as vibrações de dois instrumentos que se afinam. [...] Há algo mais profundo do que a nossa inteligência, mais profundo até mesmo do que nossa vida afetiva ou emocional: é o ritmo particular de duração pelo qual estabelecemos uma relação com outras realidades. (LAPOUJADE, 2013, p. 69).

Estamos lidando com uma duração na qual não há arrependimento, na qual não se sofre nenhuma perda, na qual não se conhece nenhum luto, na qual se vai sempre em frente, de acordo com o ritmo da novidade imprevisível própria do impulso vital..

(LAPOUJADE, 2013, p. 13).

\section{O artista-professor}

Hoje a informação desembestada dissipa-se em nuvens virtuais, disponível para livre acesso, ainda que confusa e indiferenciável para a maioria. Neste contexto recente, não é mais possível reproduzir estratégias de ensino consolidadas em outras circunstâncias, sem considerar o efeito de mudanças tão profundas na maneira de adquirir conhecimento e de conviver. O professor perdeu o seu posto central como emissor de conhecimento. Mas ganha ao abdicar de sua posição hierárquica e ao situar-se, sempre provisoriamente, como mais um ponto do rizoma contemporâneo (DELEUZE; GUATTARI, 1995b), de onde pode nutrir, em contrapartida, o seu processo reflexivo e criador. Entra em sintonia com o tempo presente ao colocar-se disponível para aprender e mudar. 
Resumamos os principais caracteres de um rizoma: diferentemente das árvores ou de suas raízes, o rizoma conecta um ponto qualquer com outro ponto qualquer e cada um de seus traços não remete necessariamente a traços de mesma natureza; ele põe em jogo regimes de signos muito diferentes, inclusive estados de não signos. O rizoma não se deixa reconduzir nem ao Uno nem ao múltiplo. Ele não é o Uno que se torna dois (...). Ele não é feito de unidades, mas de dimensões, ou antes de direções movediças. Ele não tem começo nem fim, mas sempre um meio pelo qual ele cresce e transborda. (...) Oposto a uma estrutura, que se define por um conjunto de pontos e posições, por correlações binárias entre estes pontos e relações biunívocas entre estas posições, o rizoma é feito somente de linhas (...). Oposto à árvore, o rizoma não é objeto de reprodução. (...) $\mathrm{O}$ rizoma procede por variação, expansão, conquista, captura, picada. Oposto ao grafismo, ao desenho ou à fotografia, oposto aos decalques, o rizoma se refere a um mapa que deve ser produzido, construído, sempre desmontável, conectável, reversível, modificável, com múltiplas entradas e saídas, com suas linhas de fuga. (...) Contra os sistemas centrados (e mesmo policentrados), de comunicação hierárquica e ligações preestabelecidas, o rizoma é um sistema a-centrado não hierárquico e não significante, sem General, sem memória organizadora ou autômato central, unicamente definido por uma circulação de estados. (DELEUZE; GUATTARI, 1995b, p. 33).

Considero que, hoje, a experiência de ensinar e aprender acontece como rizoma: não há hierarquia entre o saber do professor e o do aluno; não há centro ou periferia, mas sim uma multiplicidade de relações em constante movimento. O professor é o agenciador dessas relações.

Nas disciplinas práticas dos cursos de Arquitetura, Artes e Design, assim como na minha disciplina de Linguagens Visuais, o projeto desenvolvido pelo aluno norteia as atitudes do professor.
Portanto, uma conduta didática dinâmica é requisitada àquele que propõe ensinar, visto que "além de exposições e seminários, haverá uma apresentação contínua de trabalhos dos alunos, imprevisíveis, cuja orientação correta depende não só de teoria e palavras, mas de uma improvisação coerente, baseada na realização material do trabalho artístico" (BUTI, 2009). Nesse sentido, solicita-se, na atuação didática do artista-professor, a mesma atitude sensível, intuitiva e aberta ao imponderável com que conduz o seu trabalho de arte.

[...] Fundamental que o professor de artes seja, ele mesmo, um artista ou alguém que vivencia expressar-se na linguagem que solicita. Se for artista-educador, sua história na arte será importante para poder intuir caminhos ou detectar o abandono de projetos. Se já trabalhou com variadas técnicas de figuração, atento à produção que lhe é contemporânea e à História da Arte, se costuma refletir sobre alguns dos procedimentos do ato de produzir arte, saberá que esses fazeres têm muito um do outro. (DWORECKI, 1998, p. 104-105).

O acompanhamento de seus processos criativos levou-me a refletir intensamente sobre o papel do artista-professor no contexto contemporâneo da produção de imagens. Quais as diferenças e semelhanças entre os processos criativos dos alunos e o meu? Em que diferem os resultados visuais obtidos por eles daqueles que eu alcancei? Em que medida as facilidades técnicas oferecidas pelos aparelhos (câmeras fotográficas, escâneres, computadores, softwares) escamoteiam ou favorecem a consciência sobre a construção da visualidade? 
Aparelho é brinquedo e não instrumento no sentido tradicional. E o homem que o manipula não é trabalhador, mas jogador: não mais homo faber, mas homo ludens. $\mathrm{E}$ tal homem não brinca com seu brinquedo, mas contra ele. Procura esgotar-lhe o programa. Por assim dizer: penetra o aparelho a fim de descobrir-lhe as manhas. De maneira que o "funcionário" não se encontra cercado de instrumentos (como o artesão pré-industrial), nem está submisso à máquina (como o proletário industrial), mas encontra-se no interior do aparelho. Trata-se de uma função nova, na qual o homem não é constante nem variável, mas está indelevelmente amalgamado no aparelho. Em toda função aparelhística, funcionário e aparelho se confundem. (FLUSSER, 2011. p. 43).

O professor-artista, quando habituado a pensar por imagens e expressar-se por meio da visualidade, simpatiza com o movimento criador do aluno e se torna capaz de oferecer-lhe estímulos e despertar suas reflexões e ações. Mantendo sua fluência criativa, está em sintonia consigo e, portanto, mais atento ao outro. Mais que respeitar as diferenças de geração e identidade em relação aos alunos, questiono-me: como entrar em harmonia com seus desejos e sua visão de mundo? Como ser esse aluno sendo, ao mesmo tempo, seu professor?

\section{Notas sobre os processos e produtos dos alunos}

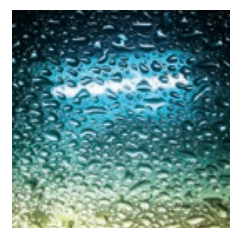

Ana Carolina Presta estuda a incidência da luz e reflexos na matéria, com variações possíveis entre seus estados sólido e líquido. A expansão da imagem na totalidade do campo visual faz com que a referência ao objeto fotografado desapareça. A imagem é uma parte do todo. “(...) Espelho é luz. Um pedaço mínimo de espelho é sempre o espelho todo" (LISPECTOR, 1998a, p. 71).

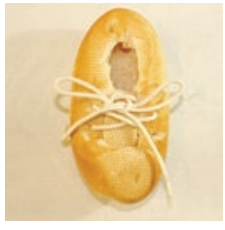

Caroline Ploennes constrói pequenos objetos inusitados, ao juntar o que jamais se esperaria ver junto. Optou por não trabalhar diretamente no computador, mas sim manipular objetos com as mãos. Caroline gosta de cozinhar e procura o que há em comum na artesania destes fazeres.

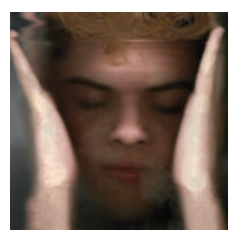

As imagens de Claudio Luiz falam de expansão e contenção a um só tempo. O espaço que seu corpo ocupa no escâner provoca uma pergunta sobre o espaço que Claudio ocupa no mundo.

"[...] Sou um formidável dinamismo obrigado ao equilíbrio

De estar dentro do meu corpo, de não transbordar da minh'alma" (PESSOA, 1983, p. 190).

Ao criar pequenas esculturas de papel amassado, Dream Choi forja a figura imaginada com as mãos, ou seja, emprega a inteligência

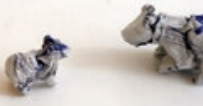
manual para dar visibilidade a fantasias. Na cena fotografada, expõe o diálogo mudo entre os animais, entre os animais e os homens. $\mathrm{O}$ embate entre natureza e fabricação. 
Erika Vanoni registra pessoas vistas de costas. Ela nos diverte com os desenhos de cada cabeça e nos faz refletir sobre o singular e o múltiplo, existência e identidade. "[...] que espécie de gente serei para os que me veem, como é a minha voz, que tipo de figura deixo escrita na memória involuntária dos outros, de que maneira os meus gestos, as minhas palavras, a minha vida aparente, se gravam nas retinas da interpretação alheia. Não consegui nunca ver-me de fora. Não há espelho que nos dê a nós como foras, porque não há espelho que nos tire de nós mesmos. (PESSOA, 2002, p. 313).

A Nas demais imagens de sua série, Fernanda Abe organiza formas - geométricas intencionalmente recortadas em tecidos. Nesta ima- $<$. gem, observa o desenho inesperado das contraformas e registra

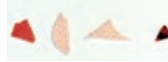
uma taxonomia das sobras, ensejando uma poética do descarte.

Fernanda Tottero e Felipe Cavalheiro dos Anjos entenderam que, para fotografar, é preciso estar próximo dos fatos. E que as imagens, apesar de mudas, comunicam. "[...] o justo emprego da linguagem é, para mim, aquele que permite o aproximar-se das coisas (presentes ou ausentes) com discrição, atenção e cautela, respeitando o que as coisas (presentes ou ausentes) comunicam sem o recurso das palavras" (CALVINO, 1990, p. 90-91).
Os desenhos de Isabela Costard nasceram a partir de um gesto livre de intenções. Ao brincar com papéis rasgados, a aluna experimentou riscar sobre seus contornos imprecisos, e o desenho naturalmente escapou para o papel de fundo. Isabela então percebeu aquilo que seria considerado um erro e o converteu em intenção, entendendo as relações existentes entre acaso e desígnio. "Bem sabemos que a palavra 'desenho' tem, originariamente, um compromisso com a palavra ‘desígnio'. Ambas se identificavam. Na medida em que reestabelecermos, efetivamente, os vínculos entre as duas palavras, estaremos também recuperando a capacidade de influir no rumo do nosso viver" (MOTTA, 1970, s.p.).

As cartografias de Isabela Monteiro Sanches acumulam-se em camadas transparentes, misturam-se com signos alfabéticos de outro tempo e espaço, configurando um livro circular, sem começo nem fim. "[...] Num livro, como em qualquer coisa, há linhas de articulação ou segmentaridade, estratos, territorialidades, mas também linhas de fuga, movimentos de desterritorialização e desestratificação. As velocidades comparadas de escoamento, conforme estas linhas, acarretam fenômenos de retardamento relativo, de viscosidade ou, ao contrário, de precipitação e de ruptura. [...]" (DELEUZE; GUATTARI, 1995b, p. 11-12).

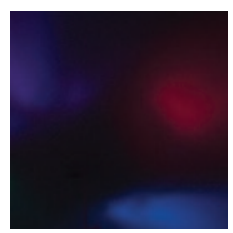

Jessica Strazzi não sabia por onde começar o trabalho. Sugeri que começasse pelo meio, que é "o lugar onde as coisas adquirem velocidade. Entre as coisas não designa uma correlação localizável que vai de uma para outra e reciprocamente, mas uma direção perpendicular, um movimento transversal que as carrega uma e outra, riacho sem início nem fim, que rói suas duas margens e adquire velocidade no meio" (DELEUZE; GUATTARI, 1995b, p. 37). A aluna não sabia o que procurava, mas soube quando encontrou. 
João Eduardo Pinhata já havia estudado na faculdade de química antes de entrar no curso de design. Propus que explorasse a matéria, e as relações entre matéria e imagem. João realizou diversos experimentos com o zoom da câmera e do photoshop. Mas, ao final das aulas, decidiu-se por perseguir e documentar os insetos, como sinais vivos no espaço da natureza. "[...] Faz parte do trabalho registrar o óbvio. Na pequena formiga cabe todo um mundo que me escapa se eu não tomar cuidado. [...] Tomar conta do mundo exige também muita paciência: tenho que esperar pelo dia que me apareça uma formiga" (LISPECTOR, 1998a, p. 56-57).

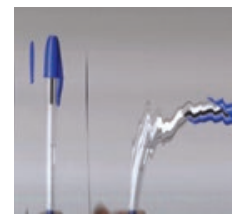

João Schmitt posiciona objetos sobre o escâner e abre a tampa do aparelho durante o processo de escaneamento. Ou seja, joga com o aparelho de uma maneira inesperada. A imagem resultante é um diagrama da sua ação. "[...] O ready-made é uma crítica da arte 'retiniana' e manual: depois de provar a si mesmo que 'dominava o ofício', Duchamp denuncia a superstição do ofício. $O$ artista não é um fazedor; suas obras não são feituras mas atos" (PAZ, 2008, p. 25).

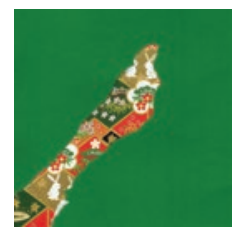

Julia Kao Igarashi trouxe para as aulas papéis de origami. Em vez das dobras precisas, típicas dessa prática oriental, sugeri que rasgasse os papéis com as mãos, sem usar tesoura ou estilete. Após a tensão do exame de vestibular, o aluno do primeiro semestre, especialmente, merece o privilégio de produzir sem almejar resultados e encontrar certa alegria na duração própria do fazer. "A criação pertence ao mundo do prazer e ao universo lúdico: um mundo que se mostra um jogo sem regras. [...] Jogar é sempre estar na aventura com palavras, formas, cores, movimentos. $\mathrm{O}$ artista vê-se diante das possibilidades lúdicas de sua matéria" (SALLES, 2004, p. 85).

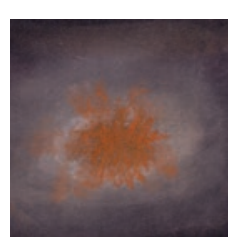

Laraíne Roque optou por realizar uma série de desenhos com giz pastel. Na apreciação do conjunto, percebo que, em alguns casos, ela atinge o estado desejável de pensar-fazendo, em vez de desenhar ideias planejadas previamente. "Agora vou escrever ao correr da mão: não mexo no que ela escrever. Esse é um modo de não haver defasagem entre o instante e eu: ajo no âmago do próprio instante" (LISPECTOR, 1998a, p. 49).

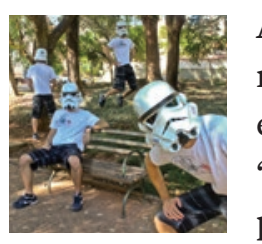

A performance de Leonardo Abreu nos lembra de que a mais anônima presença no mundo, indubitavelmente, deixará um sinal... e que não é possível separar os sinais daqueles que os emitem. "[...] o sinal lá estava onde o havia deixado para assinalar aquele ponto, e ao mesmo tempo assinalava a mim mesmo, trazia-o comigo, habitava-me, possuía-me inteiramente, intrometia-se entre mim e todas as coisas com as quais pudesse tentar relacionar-me" (CALVINO, 1992, p. 37).

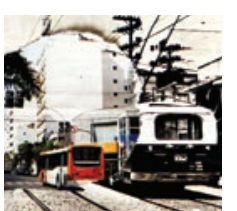

Lívia Naomi Takemura fez colagens a partir de fotografias encontradas em revistas antigas. Passeia à deriva entre os signos da cultura. Seu interesse se expande para os fatos do mundo, que manipula por meio de imagens fotográficas. "As fotos são, é claro, artefatos. Mas seu apelo reside em também parecerem, num mundo atulhado de relíquias fotográficas, ter o status de objetos encontrados lascas fortuitas do mundo. Assim, tiram partido simultaneamente do prestígio da arte e da magia do real. São nuvens de fantasia e pílulas de informação" (SONTAG, 2004, p. 84). 
Mateus Dal Vesco registra da sua janela nuvens e ruídos, vestígios informes e passageiros de cada dia.

"sem sair de casa

conhece-se o mundo

sem espiar pela janela

quanto mais longe se vai

vê-se o curso do céu

tanto menos se conhece"

(LAOZI, 2002, p. 47).

Ao captar a sombra da árvore no chão, Sabrina Duarte desenha um desejo de lugar. Posiciona a linha do horizonte fotografado, precisamente, na espinha do livro. Os planos horizontal e vertical - chão e ar - dividem-se nas páginas opostas, formando também no livro um ângulo de $90^{\circ}$. 
[...] Não é a questão da liberdade, mas a da saída. Onde está aquela pequena linha heterogênea que escapa ao sistema, qual o elemento que vai desempenhar o papel da singularidade, o que é aquilo que fará o conjunto fugir? Nesse sentido, é sempre de uma política que se trata, de um protocolo de experimentações, por meio da voz, do som, dos gestos, dos devires mais insólitos. A pergunta não é que se quer dizer, mas como se entra, como se sai, como se foge, como se escapa - ou seja, mais do que posições, estados do desejo em relação a uma máquina: a máquina da justiça, a máquina familiar, a máquina capitalista, a máquina tecnocrática... Que linhas, que processos, que caminhos, que adjacências se inventam ao abrir os becos sem saída, ao desbloqueá-los. É uma leitura mais intensiva do que significante, mais geográfica do que histórica, mais da ordem das linhas do que das estruturas. (PELBART, 2007, p. 287-288). 


\section{Lista de imagens}

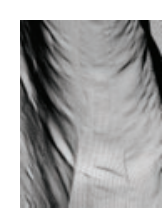

p. 23

p. 23
Ventos, 2002

Fotografia digital

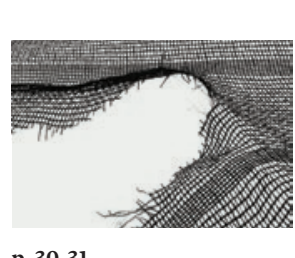

p. $\mathbf{3 0 - 3 1}$
Ventos, 2002

Fotografia digital

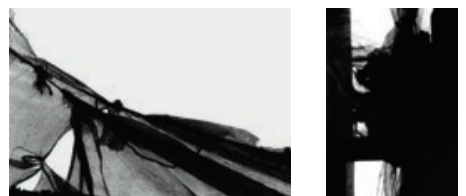

p. 36

Ventos, 2005

digita

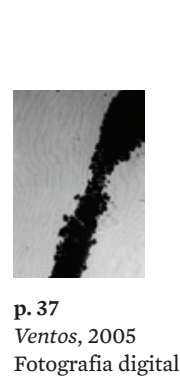

p. 37

Ventos, 2005

Fotografia digital p. 36

Ventos, 2005

Fotografia digital

p. 37
Ventos, 2005

Fotografia digita

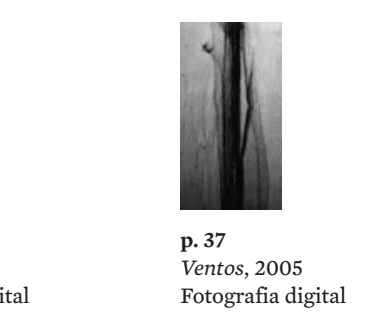

p. 24-25

Fotografia digital

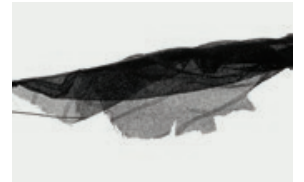

p. 32-33

Fotografia digital

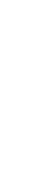

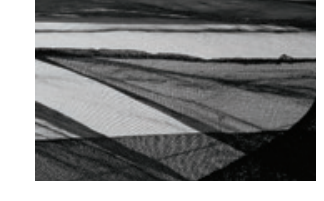

p. 26-27

Ventos, 2002

Fotografia digita

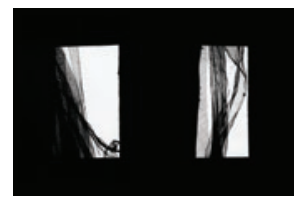

p. 34-35

Fotografia digital

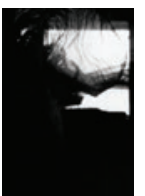

p. 36

Ventos, 2005

Fotografia digital

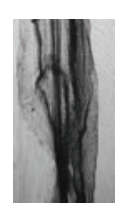

p. 37
Ventos, 2005

Fotografia digita

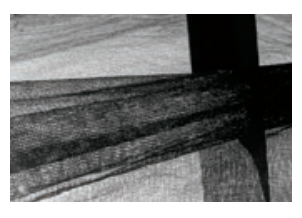

p. 28-29

Ventos, 2002

Fotografia digital

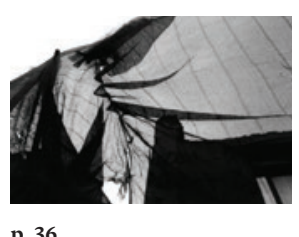

p. 36

Fotografia digital
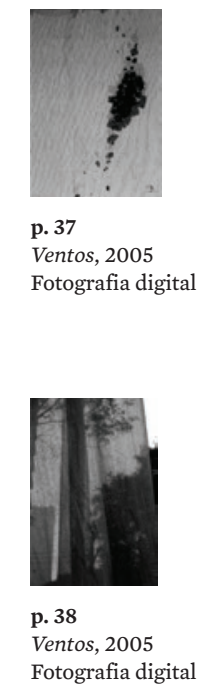


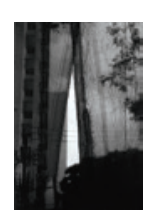

p. 38

Ventos, 2005

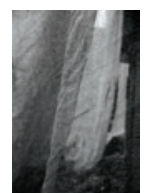

p. 39

Ventos, 2005

Fotografia digital

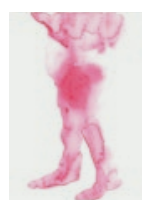

Desenho de observação, 2010 Aquarela sobre papel

de algodão

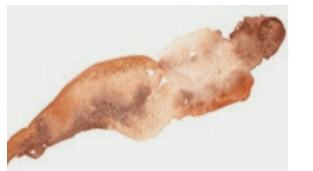

p. 48-49
Desenho de observação, 2011

Aquarela sobre papel

de algodão

$12,5 \times 18 \mathrm{~cm}$

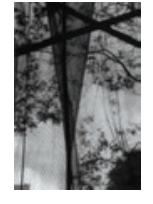

p. 38
Ventos, 2005

Fotografia digital

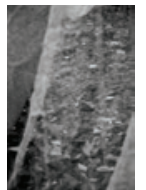

p. 39

Ventos, 2005

Fotografia digital

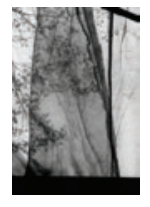

p. 38

Ventos, 2005

Fotografia digital

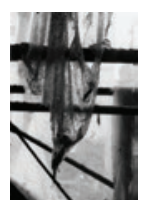

p. 3

Fotografia digital

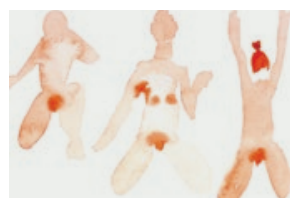

p. 44
Desenho de observação, 2010 Aquarela sobre papel

de algodão

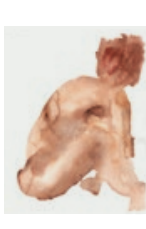

Desenho de observação, 2011 Aquarela sobre papel de algodão

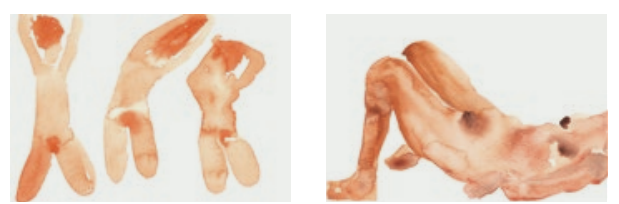

Desenho de observação, 2010 Aquarela sobre papel

de algodão

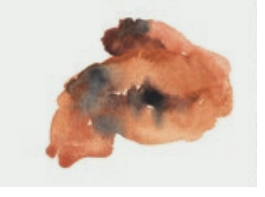

Desenho de observação, 2011 Aquarela sobre papel de algodão
$12,5 \times 18 \mathrm{~cm}$

Desenho de observacão, 201 Bico de pena e tinta sobre papel Fabriano Schizzi

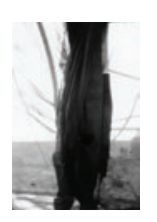

p. 39

Ventos, 2005

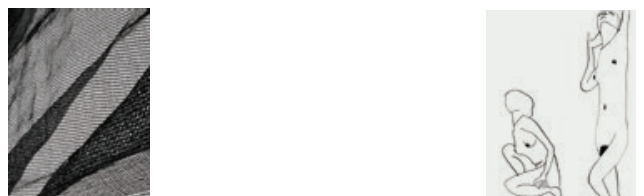

p. 40

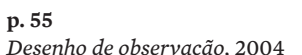

Desenho de observação, 2004
Lápis grafite sobre

papel sulfite

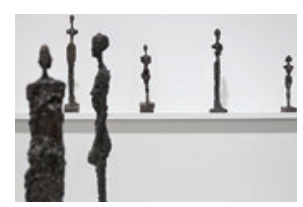

p. 61

() Zé Carlos Barretta/

Folhapress, 2012

Exposicăo de Giacometti na

Pinacoteca de São Paulo

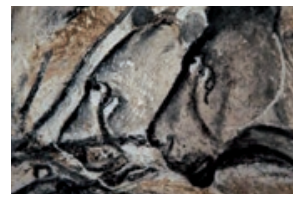

Desenho de observação, 20 Bico de pena e tinta sobre $29,7 \times 21 \mathrm{~cm}$

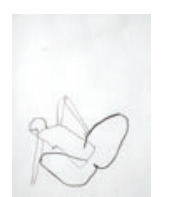

Desenho de observacĩo, 2003 Monotipia sobre papel japonês

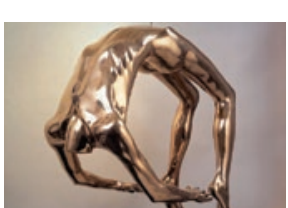

p. 61

Louise Bourgeois Arco da histeria, 1993 Exposição no Instituto Tomie Ohtake

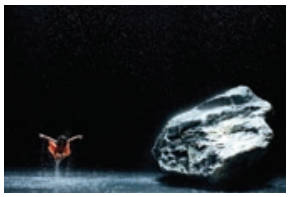

p. 61
Filme A caverna dos sonhos esquecidos, 2010 p. 61 Wim Wenders

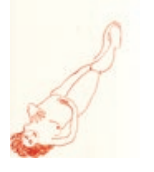

Desenho de observação, 201 Bico de pena e tinta sobre papel Fabriano Schizzi $29,7 \times 21 \mathrm{~cm}$

\section{$D=-$ \\ p. 57}

Desenho de observação, 2003 Monotipia sobre $29 \times 21 \mathrm{~cm}$

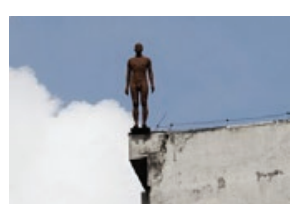

\section{p. 61}

() Caio Kenji/G1

Antony Gormley

Event Horizon, 201

são Paulo, Brasil

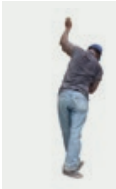

p. 63

Fotografia e recorte digital

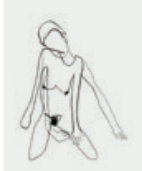

Desenho de observação, 2004 Lápis grafite sobre $29,7 \times 21 \mathrm{~cm}$
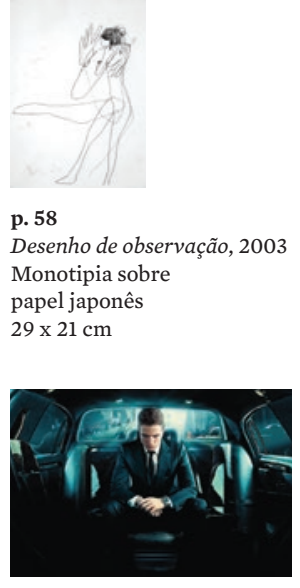

p. 61

Filme Cosmópolis, 2012 David Cronenberg

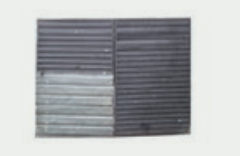

p. 64

Fotografia e recorte digital 


\section{Sty}

p. 65
Vazios, 2005

Fotografia e recorte digital

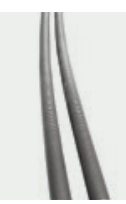

p. 69

Vazios, 2005

Fotografia e recorte digital

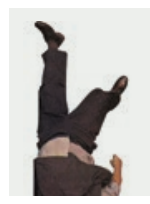

p. 75
Vazios, 2006

Escaneamento

recorte digital

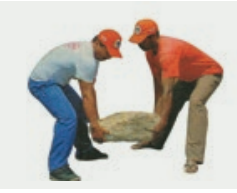

p. 79

Vazios, 2006

recorte digital

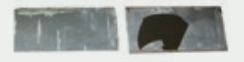

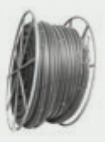$$
\text { p. } 66
$$

p. 66
Vazios, 2005

p. 67

Fotografia e recorte digital

Vazios, 2005

Fotografia e recorte digital

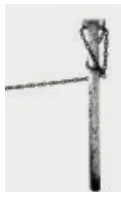

p. 71

p. 70

Vazios, 2005

so, 2005

Fotografia e recorte digital

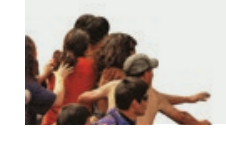

p. 72

Vazios, 2006

Escaneamento

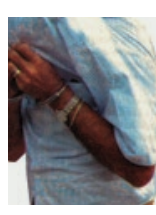

p. 78

Vazios, 2006

Escaneamento

recorte digital

Escaneamento

recorte digital

Escaneamento e

recorte digital

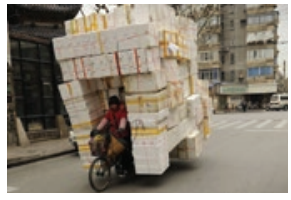

p. 84
(c) Peter Parks/France Press folha.uol.com.br

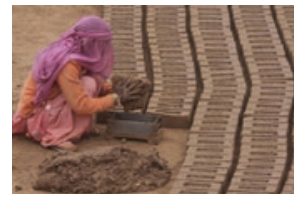

p. 84 Ajay Verma/Reuters folha.uol.com.br

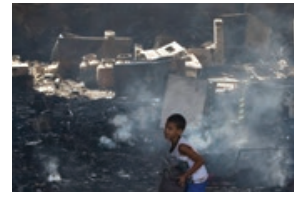

p. $\mathbf{8 4}$
c) Apu Gomes/Folhapress folha.uol.com.br

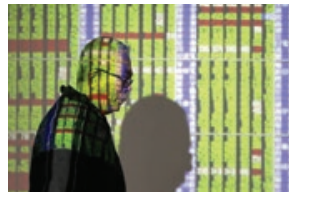

p. 84
(c) Pichi Chuang/Reuters folha.uol.com.br
Taipei, Taiwan

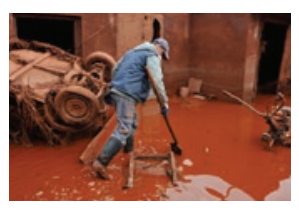

p. 84

๑ AP Photo/Bela Szandelszky cbsnews.com

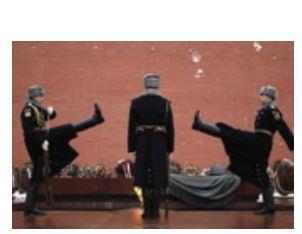

p. 84

(c) Pawel Kopczynski/

Reuters

folha.uol.com.b

Moscou, Rússia

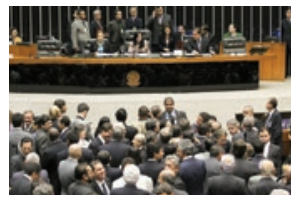

p. 85

(c) Lula Marques/Folhapress Brasília, Brasil

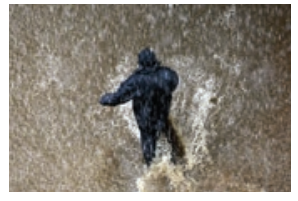

p. 84

c) Hussein Malla/Associated

folha.uol.com.br

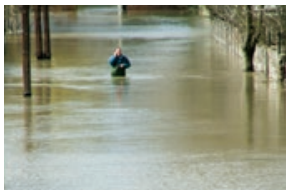

p. 84

commons.wikimedia.or Esztergom, Hungria

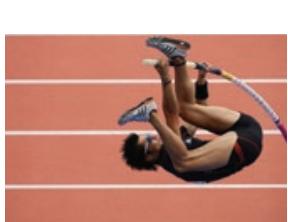

(c) Tsutomu Takasu

Creative Commons

commons.wikimedia.org

Kanagawa, Japão

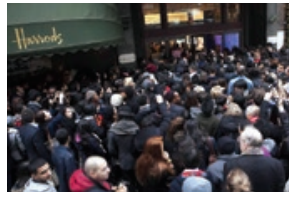

p. 85
(c) Finbarr O'Reilly/Reuters folha.uol.com.br

Londres, Reino Unido

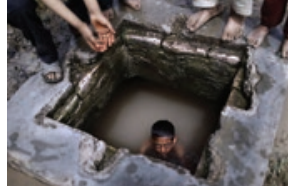

p. 84 Associated Press

Islamabad, Paquistão

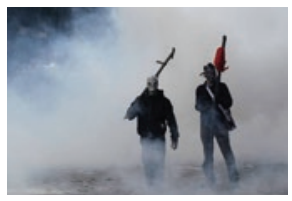

p. 84

(c) Petros Giannakouris/ Associated Press

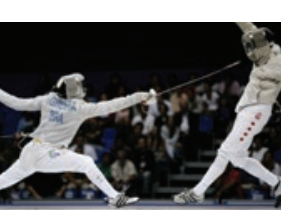

\section{p. 84}

C. Lalo de Almeida/

Folhapress

Rio de Janeiro, Brasi

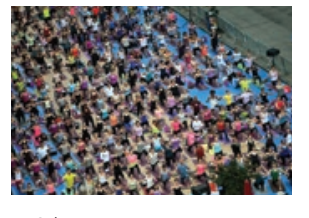

p. 85 Emmanuel Dunand/

France Presse

folha.uol.com.br

Nova York, Estados Unidos

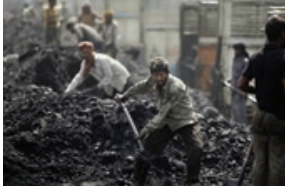

p. 84

Channi Anand/ Associated Press Jammu, Îndia

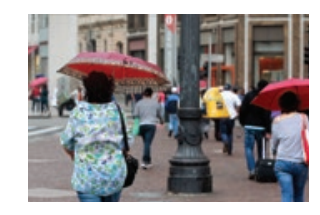

p. 84

c) Rivaldo Gomes/

Folhapress

São Paulo, Brasil

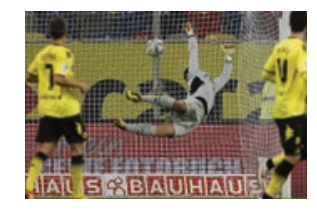

p. 84 Ina Fassbender/Reuters

folha.uol.com.br

Düsseldorf, Alemanha

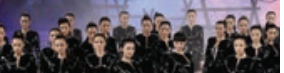
athen Hotog $4 \%$ \& ${ }^{2}=$ p. 85 Jason Lee/Reuter Pequim, China 


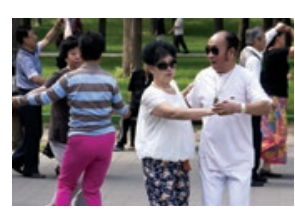

p. 85
(c) Adrian Bradshaw/Efe folha.uol.com.br

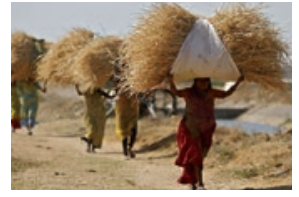

p. 85
(c) Amit Dave/Reuter folha.uol.com.br Ahmedabad, Índia

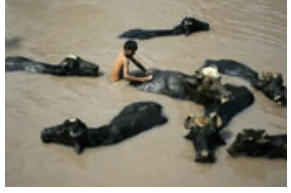

p. 85
() Fayyaz Hussain/Reuters folha.uol.com.br Faisalabad, Paquistão

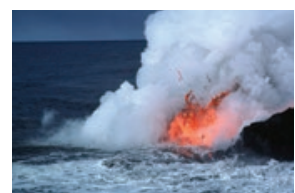

p. 85

commons.wikimedia.org

Havaí

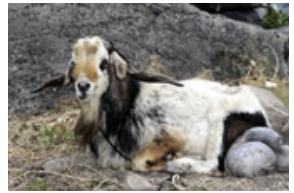

p. 85

(c) Carlos Fernandez/Ef

folha.uol.com.br

Hermigua, Espanha

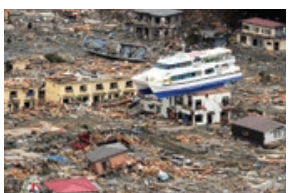

Asahi Shimbun/Efe

folha.uol.com.br

(c) Sana/Associated Pres

folha.uol.com.b

Kyodo News

folha.uol.com.

Ibaraki, Japão
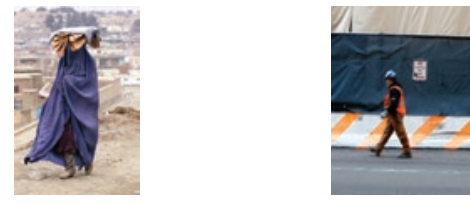

p. 86

Afeganistão p. 86
Foto da autora, 2008

Nova York, Estados Unidos

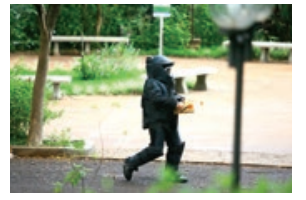

p. 87

Divulgação $\mathrm{HC}$

Ribeirão Preto, Brasi

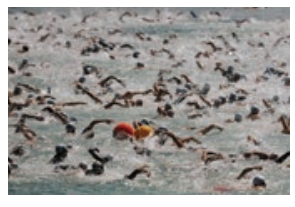

p. 85
(c) Vanderlei Almeida/

France Presse

Rio de Janeiro, Brasil

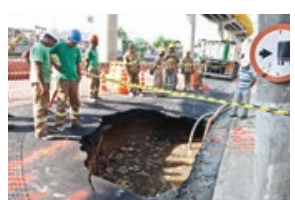

p. 85

(c) Danilo Verpa/Folhapress

folha.uol.com.br

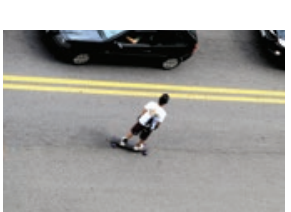

\section{p. 86}

Foto da autora, 2012

São Paulo, Brasil

(c) Victoria Hazou/

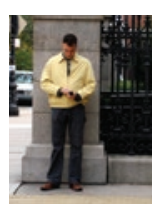

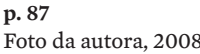

Nova York, Estados Unidos

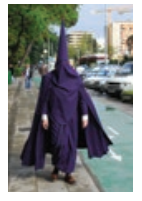

p. 87

Creative Commons

commons.wikimedia.org Sevilha, Espanha

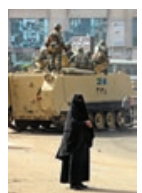

p. 89 Associated Press/AE/

ae.com.br

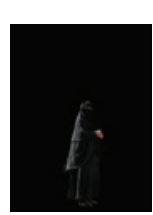

p. 93
Cenas, 2012

Cenas, 2012

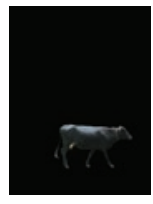

p. 97

Colagem digital

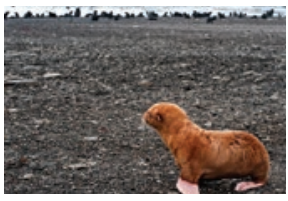

p. 88

Carters News Agency gl.globo.com

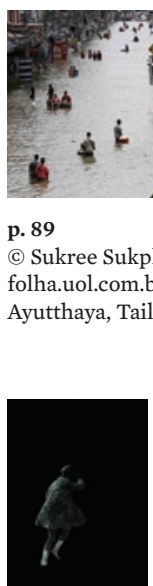

p. 94
Cenas, 2012

Colagem digital

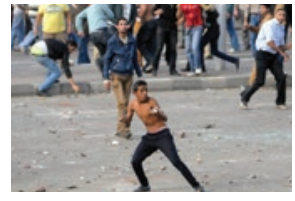

p. 88

folha.uol.com.br

Alexandria, Egito

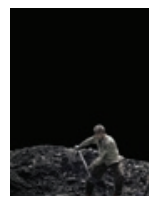

p. 91

Cenas, 2012
Colagem digital

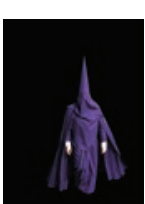

p. 95

Cenas, 2012

Colagem digital

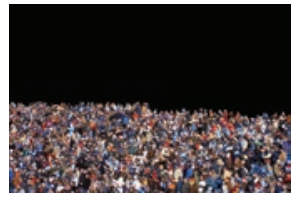

p. 98-99

Cenas, 2013
Colagem digital

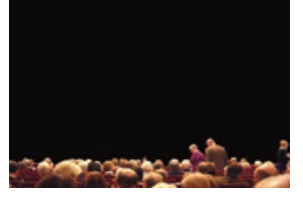

p. 100-101

Colagem digital

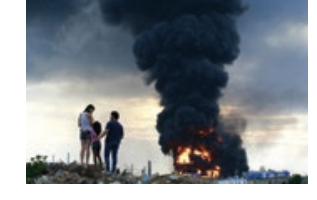

p. 88-89

( $)$ Gil Montano/Reuter

folha.uol.com.br

Punto Fijo, Península

de Paraguaná
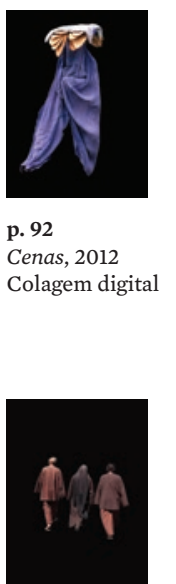

p. 96
Cenas, 2013

Colagem digital

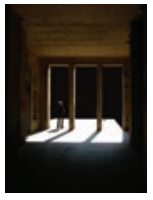

p. 102 


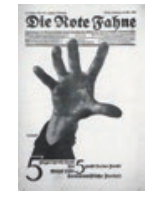

p. 103

Heartfield The Hand Has Five Fingers,

johnheartfield.com

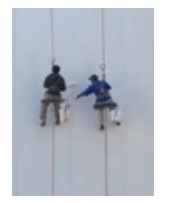

p. 104

Foto da autora, 2012

São Paulo, Brasil

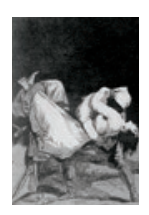

p. 105

Francisco Goya

Capricho No. 08 Que se

la llevaron!, 1797-1799

Gravura em met

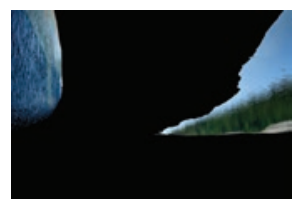

p. 112-113

Corpos de água, 2013

Colagem digital

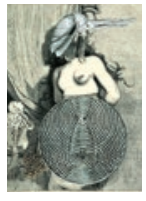

p. 103

Max Ernst

Colagem La clé des chants 1 da série Une semaine de

bonté, 1933
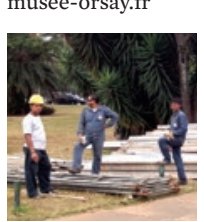

p. 104

Foto da autora, 201

São Paulo, Brasil

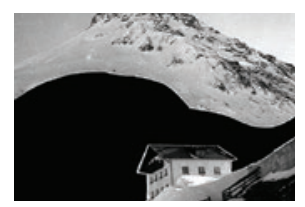

p. 105

Geraldo de Barros

Sobras, 1998

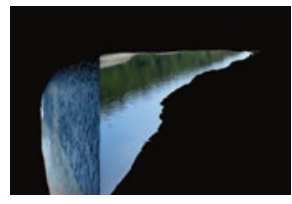

p. 114-115

Corpos de água, 2013

Colagem digital

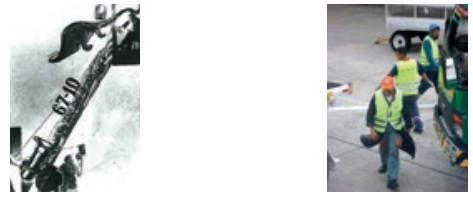

p. 103
Alexander Rodchenko

Fotomontagem para poema Pro Eto de Vladimir

p. 104

São Paulo, Brasil

museenkoeln.de

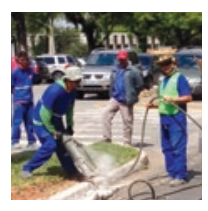

p. 104

Foto da autora, 2013

São Paulo, Brasil

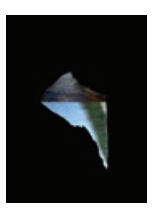

p. 109

Corpos de água, 2013

Colagem digital

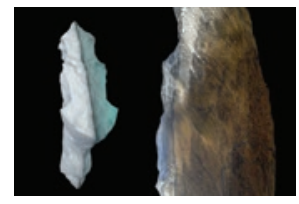

p. 116-117

Corpos de água, 2013

Colagem digital

p. 105

Fotografia

p. 110-111

Corpos de água, 2013

Colagem digital

p. 118-119

Colagem digital

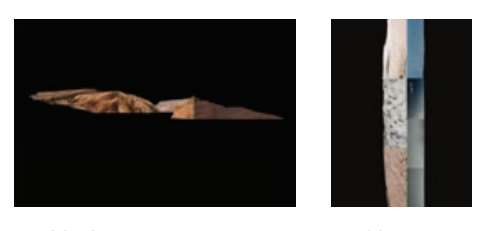

p. 120-121

Colagem digital

p. 122

Corpos de água, 2013

Colagem digital

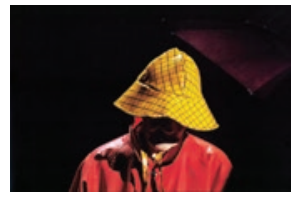

Philip-Lorca diCorci
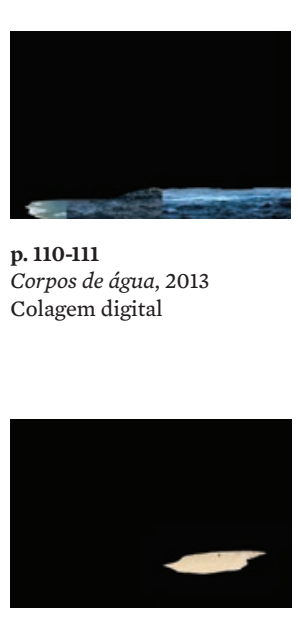

Corpos de água, 2013

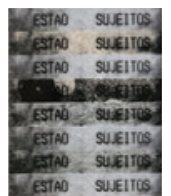

p. 128-129

Comprovantes, 2012

bre papel colo

plus e papel timbo

$48 \times 40 \mathrm{~cm}$

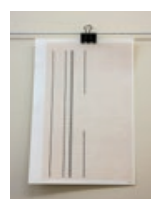

p. 132

Comprovantes, 2012

Impressão jato de tinta sobre

papel milimetrado

$08: 23: 52$
$08: 43: 42$

09:52:31

10:21:11

11:06:30

17:06:34

18:14:23

p. 138

Impressão jato de tinta sobr

papel roller $62 \times 22 \mathrm{~cm}$ p. 130-131

$36 \times 80 \mathrm{~cm}$

*7+

点番

$4 * 4$

p. 125

Arquivo digital 2012

p. 126-127

Arquivo digital
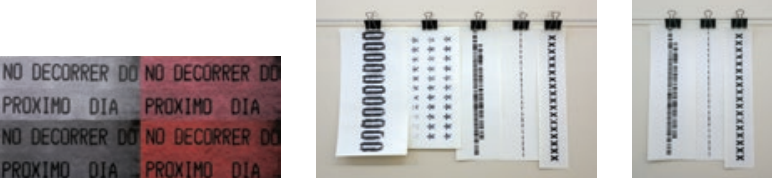

p. 132

pel colo

essão jato de tinta sobre

Dimensões variáveis

p. 132

Comprovantes, 2012

ressão jato de tinta sobre papel Fabriano Schizzi Dimensões variáveis

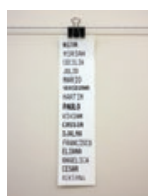

Comprovantes, 201

papel Fabriano Schizzi

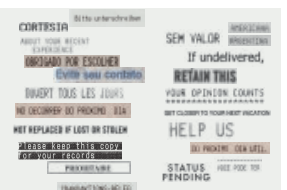

p. 134-135

Arquivo digital

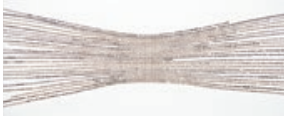

p. 14

Jorge Macchi

Cuerpos sin vida, 2003 Colagem sobre papel

Comprovantes, 20

Arquivo digital
Impressão jato de tinta so

ARRIVE ALIVEEvite seu contato w $\mathrm{I}$ 두믄

p. 136-137

Comprovantes, 2013 Arquivo digital p. 14

Cuerpos sin vida, 2003 Colagem sobre papel 


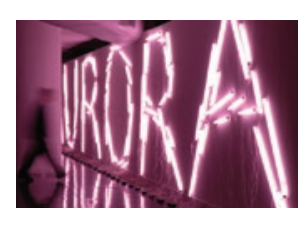

p. 144

Carmela Gross

Lâmpadas tubulares

$3 \times 30 \mathrm{~m}$

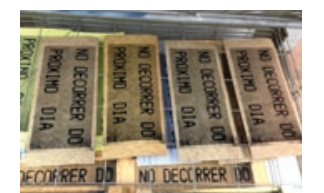

p. 147

Foto da autora, 2012

Provas impressa

em serigrafia

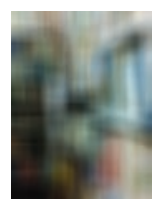

p. 154

Cor-luz, 2013

Fotografia digital

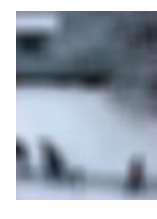

p. 158
Cor-luz, 20

Fotografia digital

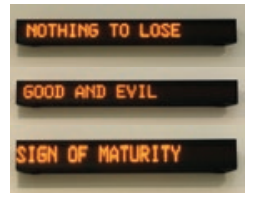

p. 144

Jenny Holzer

Truisms, 1984

$169 \times 1539 \times 162 \mathrm{~mm}$

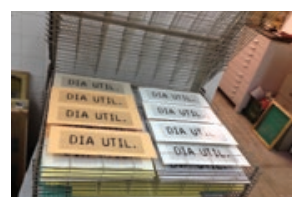

p. 147

Foto da autora, 2012

Provas impressas

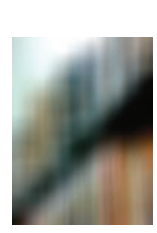

p. 155
Cor-luz, 2013

Fotografia digital

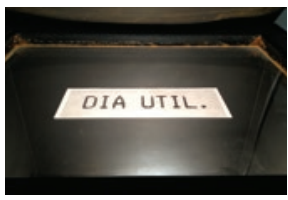

p. 146

p. 146
Foto da autora, 2012

Gravação da tela

de serigrafia

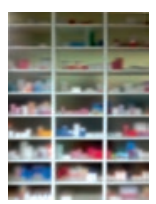

p. 151

Fotografia digital

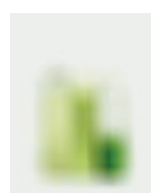

p. 156
Cor-luz, 2013

Fotografia digital

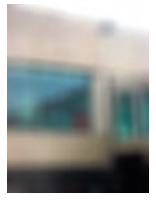

p. 160

Fotografia digital
Cor-luz, 2013

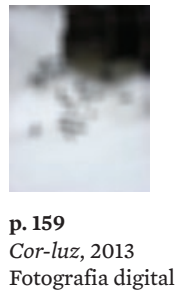

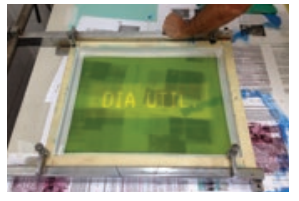

p. 146

Posicionamento da tel

de serigrafia para impressão

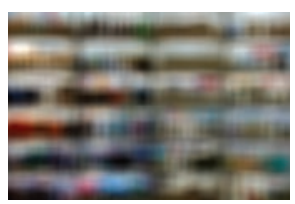

p. 152-153

Fotografia digital

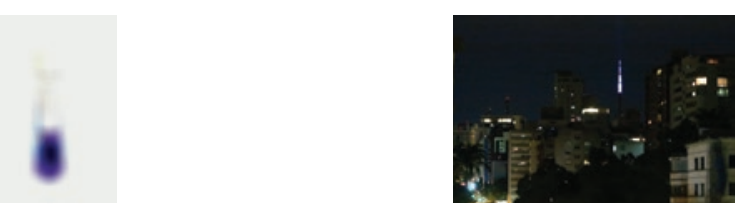

Cor-luz, 2013

Fotografia digital

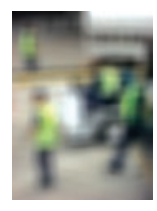

p. 161

Fotografia digital

p. 162

For-luz, 2013

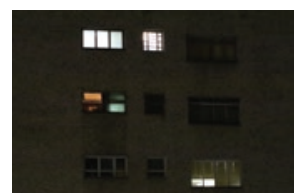

p. 166

Cor-luz, 2013

-

Fotografia digital p. 166

Cor-luz, 2013

Fotografia digital

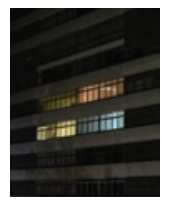

p. 167
Cor-luz, 2013

Fotografia digital

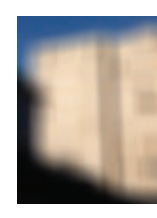

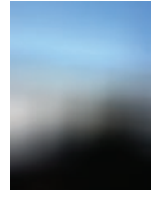

p. 163
Cor-luz, 20

Fotografia digital

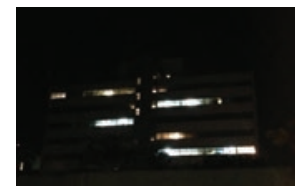

p. 166

Cor-luz, 2013

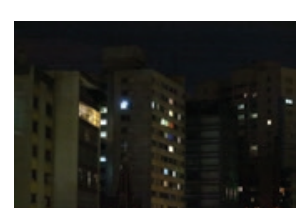

p. 166
Cor-luz, 2013

Cor-luz, 2013

Fotografia digita

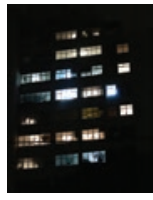

p. 167

Fotografia digital

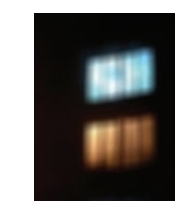

p. 164
Cor-luz, 2013

Fotografia digital

p. 165

Cor-luz, 2013

Fotografia digital

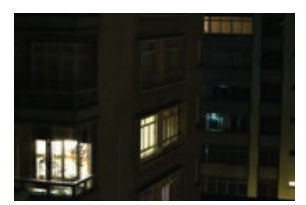

p. 166

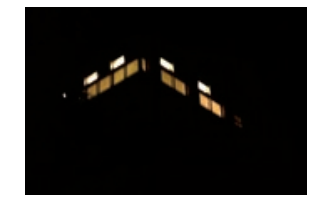

p. 166

Cor-luz, 2013

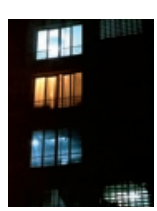

\section{p. 167}

Cor-luz, 2013

Fotografia digital

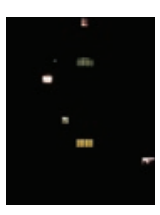

p. 167

Cor-luz, 2013

Fotografia digital

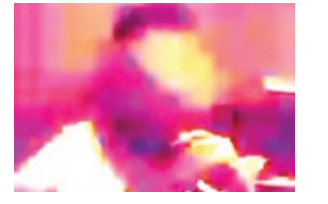

p. 168-169

Fotografia digital

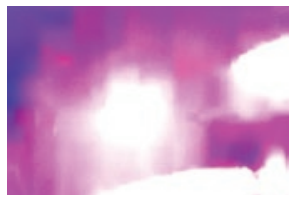

p. 170-171
Cor-luz, 2013

Fotografia digital 


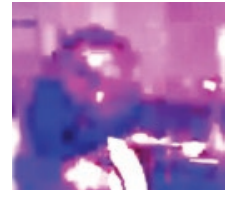

p. 172

Cor-luz, 2013

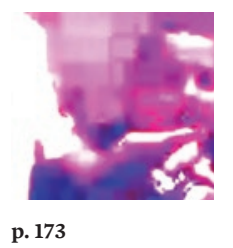

Cor-luz, 2013

Fotografia digital

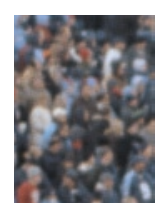

p. 174
Cor-luz, 2013

Fotografia digital

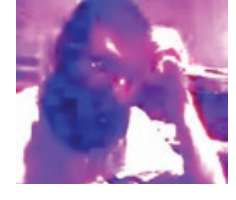

p. 172
Cor-luz, 2013

Fotografia digital

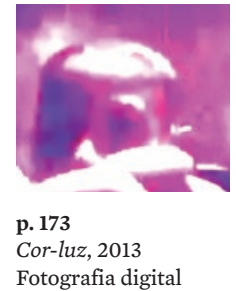

Fotografia digital

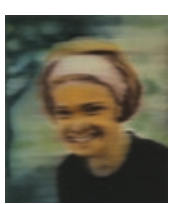

p. 17

Gerhard Richter

Inge, 1965

$40 \times 35 \mathrm{~cm}$

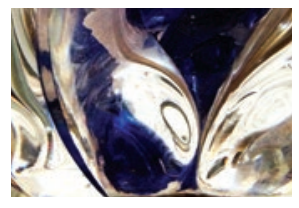

p. 180-181

(c) Ana Carolina Presta

Fotografia digital

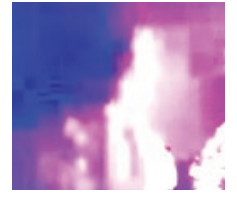

p. 172

Cor-luz, 2013
Fotografia digital

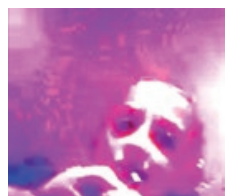

p. 173

Cor-luz, 2013

Fotografia digital

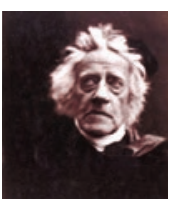

p. 176

Julia Margaret Camero

Sir John Herschel, 1867

Fotografia

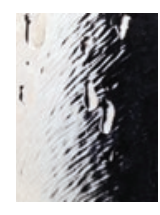

p. 184
( Ana Carolina Presta Um sinal no espaço, 2013
Fotografia digital

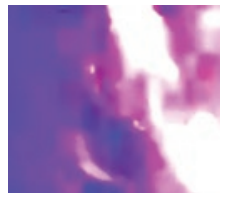

p. 172

Fotografia digit
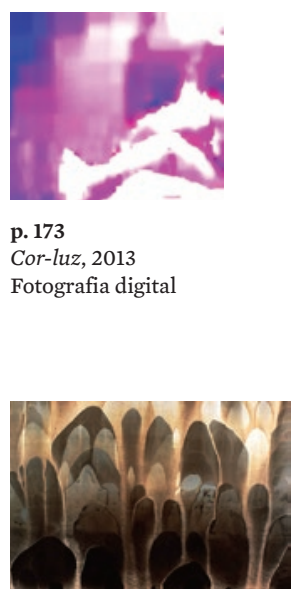

p. 176
Pierre Cordier

Quimigrama, 200

Fotografia

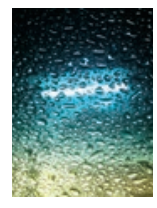

p. 185
(c) Ana Carolina Presta

Um sinal no espaço, 2013

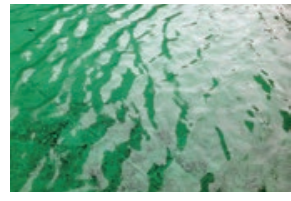

p. 186-187

(c) Ana Carolina Presta

Fotografia digital

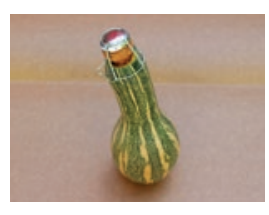

p. 189

(c) Caroline Ploennes

Um sinal no espaço, 20

Montagem de obje

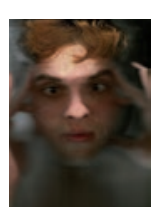

p. 193
(c) Claudio Luiz

Um sinal no espaço, 2013

Escaneamento

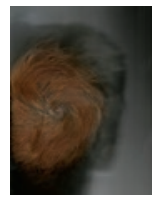

p. 197

Um sinal no espaço, 2013 Escaneamento

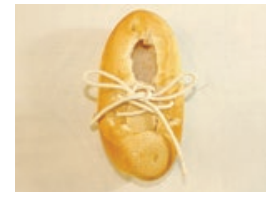

p. 188 Um sinal no espaço, 2013 e fotografia digital

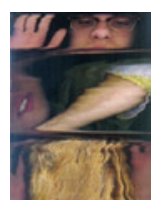

p. 190

c) Claudio Luiz

Um sinal no espaço, 2013

Escaneamento

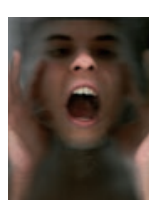

p. 194

P. 194

Um sinal no espaço, 201

Escaneamento

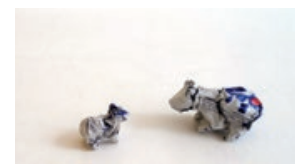

p. $198-199$

(c) Dream Choi

Um sinal no espaço, 2013

Escultura e fotografia

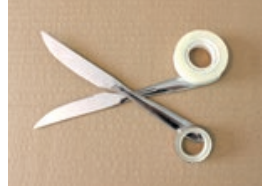

p. 188

p. 188 Caroline Ploennes

Um sinal no espaço, 201 Montagem de objetos e fotografia digital

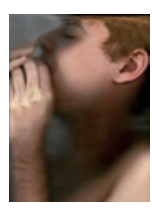

p. 191

() Claudio Luiz

espaço, 2013

Escaneamento

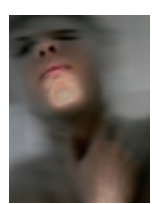

p. 195

(c) Claudio Luiz

Um sinal no espaço, 2013

Escaneamento

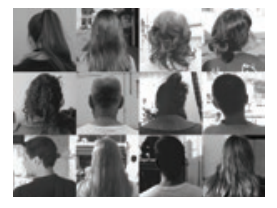

p. 200-201

(c) Erika Vanoni

Um sinal no espaço, 2013

Fotografia digital

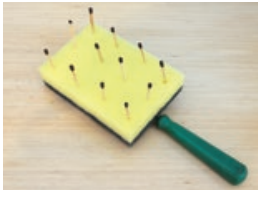

p. 189

c) Caroline Ploennes e fotografia digital

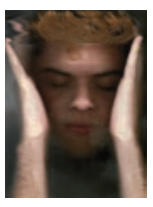

p. 192

(c) Claudio Luiz

Um sinal no espaço, 2013

Escaneamento

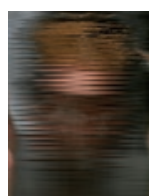

p. 196

() Claudio Luiz

Um sinal no espaço, 2013 Escaneamento

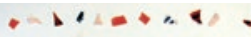
man

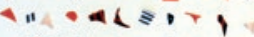
- inalans 1, , , :, $1=$ p. 202-203

(c) Fernanda Abe

Um sinal no espaço, 2013 Colagem 


\section{re} p. 204-205

(c) Fernanda Tottero e Felipe Cavalheiro dos Anjos Um sinal no espaço, 2013

Fotografia digital

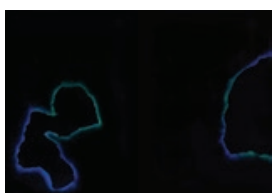

p. 210

(c) Isabela Costard

Um sinal no espaço, 2013

Lápis de cor sobre papel

$29,7 \times 42 \mathrm{~cm}$

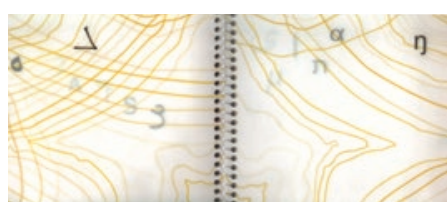

p. 212-213

(c) Isabela Monteiro Sanches

Um sinal no espaço, 2013

Desenho sobre papel vegeta

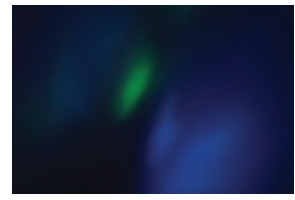

p. 218-219

(c) Jessica Strazzi

Um sinal no espaço,

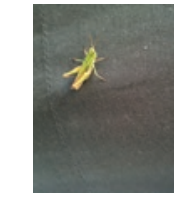

p. 220

Um sinal no espaço Pinhata Fotografia digital

p. 210

Um sinal no espaço, 201

or sobre papel

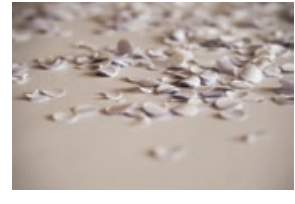

p. 208-209

(c) Fernanda Tottero e

Felipe Cavalheiro dos Anjos

Um sinal no espaço, 2013

Fotografia digital

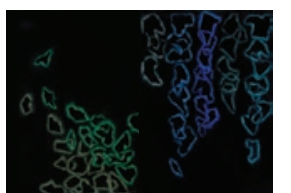

p. 211

Isabela Costard

Um sinal no espaço, 2013

Lápis de cor sobre papel

$29,7 \times 42 \mathrm{~cm}$

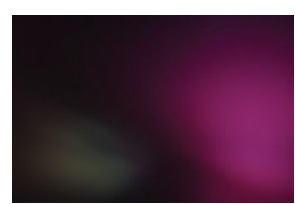

p. 214-215

(c) Jessica Strazzi

Um sinal no espaço, 201

Fotografia digita

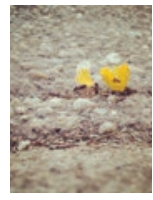

p. 221

p. 221 João Eduardo Pinhata

Um sinal no espaço, 2013
Fotografia digital

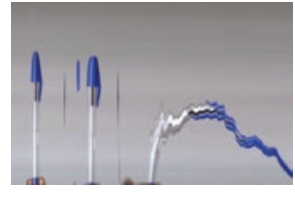

p. 224-225

() João Schmitt

Um sinal no espaço, 2013

Escaneamento

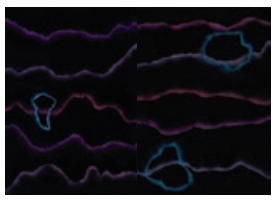

p. 211

Um sinal no espaço, 2013

re papel

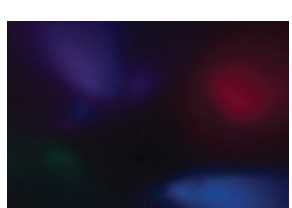

p. 216-217

๑) Jessica Strazzi

Um sinal no espaço, 2013

Fotografia digital

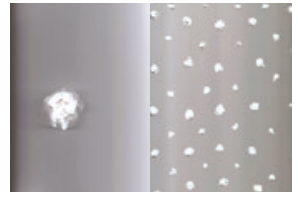

p. 222-223

() João Schmitt

Um sinal no espaço, 2013

Escaneamento

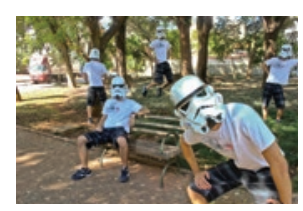

p. 232-233

(c) Leonardo Abreu

Fotografia digital

p. 238-239

(c) Mateus Dal Vesco

Um sinal no espaço, 2013

Fotografia e colagem digital

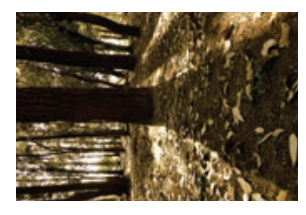

p. 242-243

Um sinal no espaco, 2013

Fotografia digital

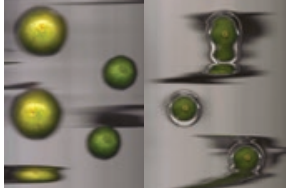

p. 226-227

(๔) João Schmitt

Um sinal no espaço, 201

Escaneamento
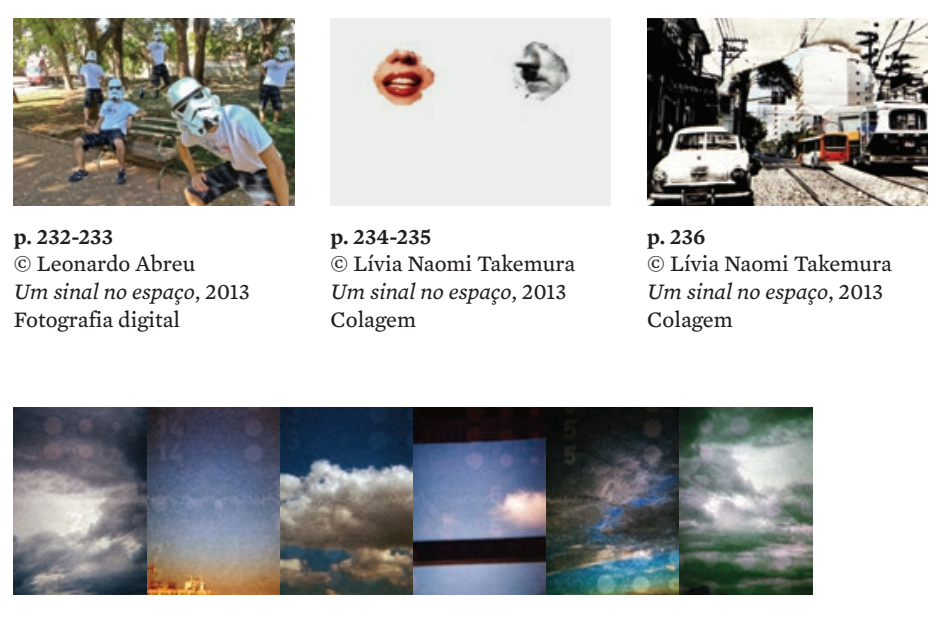

p. 234-235

(c) Lívia Naomi Takemura

Um sinal no espaço, 2013

Colagem

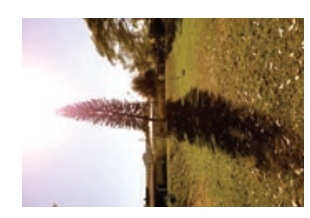

p. 244-245

Um sinal no espaço, 2013 p. 236

c) Lívia Naomi Takemura

Um sinal no espaço, 2013

Colagen

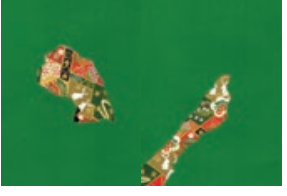

p. 228-229

Julia Kao Igarashi

Colagem

Laraíne Roque

Um sinal no espaço, 2013

Pastel seco sobre papel

$14,8 \times 21 \mathrm{~cm}$

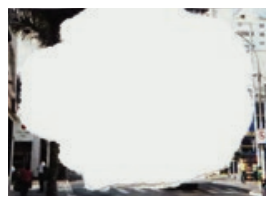

p. 237

Lívia Naomi Takemura

Um sinal no espaço, 2013

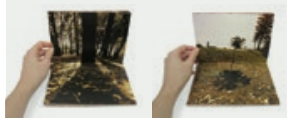

p. 240-241

pabrina Duarte fotografado pela autora, 2013 


\section{Referências bibliográficas}

AGAMBEN, Giorgio. O que é o contemporâneo? e outros ensaios. Chapecó: Argos, 2009.

ANDRADE, Mário de. O artista e o artesão. In: Curso de filosofia e história da arte; Anteprojeto do Serviço do Patrimônio Histórico e Artístico. São Paulo: Centro de Estudos Folclóricos do Gfau, 1955.

ARCHER, Michael. Arte contemporânea: uma história concisa. São Paulo: WMF Martins Fontes, 2012.

BACHELARD, Gaston. A poética do espaço. São Paulo: Martins Fontes, 2008.

BARTHES, Roland. A câmera clara: notas sobre a fotografia. Rio de Janeiro: Nova Fronteira, 1984

BENJAMIN, Walter. A obra de arte na era de sua reprodutibilidade técnica. In: Magia e Técnica, Arte e Política. Ensaios sobre literatura e história da cultura. Obras Escolhidas. Vol. 1. São Paulo: Brasiliense, 1994.

BENSON, Richard. The printed picture. New York: The Museum of Modern Art, 2009.

BOURGEOIS, Louise. Destruição do pai, reconstrução do pai: escritos e entrevistas 1923-1997. São Paulo: Cosac Naify, 2000.

BOURRIAUD, Nicolas. Estética relacional. São Paulo: Martins, 2009.

$$
\text { Pós-produção: como a arte reprograma o mundo }
$$

contemporâneo. São Paulo: Martins, 2009.

BUCKLEY, Brad; Conomos, John. Rethinking the contemporary art school: the artist, the $P h D$, and the academy. Halifax: The press of Nova Scotia College of Art and Design, 2009. 
BUTI, Marco. 8.03: A Arte na Universidade, A Universidade na Arte. ARS (São Paulo), São Paulo, v. 7, n. 14, 2009. Disponível em: <http://www. scielo.br/scielo.php?script=sci_arttext\&pid=S1678-

53202009000200009\&lng=en\&nrm=iso>. Acesso em: 16/05/2013.

\section{Caros artistas, pesquisem. É suficiente. ARS (São}

Paulo), São Paulo, v. 3, n. 6, 2005. Disponível em: < http://www.scielo.br/ scielo.php?script=sci_arttext\&pid=S1678-53202005000200007\&lng=en\& $\mathrm{nrm}=$ iso $>$. Acesso em: 16/05/2013.

CALVINO, Ítalo. As cosmicômicas. São Paulo: Companhia das Letras, 1992.

Palomar. São Paulo: Companhia das Letras, 1994.

Companhia das Letras, 1990.

CANTON, Katia. Coleção temas da arte contemporânea. São Paulo: WMF Martins Fontes, 2009.

CELANT, Germano. Arte Povera. Milano: Mazzotta, 1969.

CHAUÍ, Marilena. Laços do desejo. In: NOVAES, Adauto. O desejo. São Paulo: Companhia das Letras, 1990.

CHENG, François. Empty and full: the language of Chinese painting. Boston: Shambhala, 1994.

COTTON, Charlotte. A fotografia como arte contemporânea. São Paulo: WMF Martins Fontes, 2010

DEBORD, Guy. A sociedade do espetáculo. Rio de Janeiro: Contraponto, 2004.

DELEUZE, Gilles; GUATTARI, Félix. Como criar para si um corpo sem órgãos. In: Mil Platôs: capitalismo e esquizofrenia, vol. 3. São

Paulo: Editora 34, 1995a.
Introdução: Rizoma. In: Mil

Platôs: capitalismo e esquizofrenia, vol. 1. São Paulo: Editora 34, 1995b.

DERDYK, Edith (org.). Disegno. Desenho. Desígnio. São Paulo: Senac, 2007. São Paulo: Senac, 2013.

DEWEY, John. Arte como experiência. São Paulo: Martins Fontes, 2010

DOMINGUES, Diana. Arte e vida no século XXI: tecnologia, ciência e criatividade. São Paulo: Unesp, 2003.

DUBOIS, Philippe. $O$ ato fotográfico e outros ensaios. Campinas: Papirus, 1993.

DUCHAMP, Marcel. O ato criador, 1965. Disponível em: <http://www. scribd.com/doc/168777318/Duchamp>. Acesso em: 30/09/2013.

DWORECKI, Silvio. Em busca do traço perdido. São Paulo: Scipione Cultural: Edusp, 1998.

ECO, Umberto. Obra aberta: forma e indeterminação nas poéticas contemporâneas. São Paulo: Perspectiva, 2005.

FARIAS, Agnaldo. Aurora. In: São Paulo das mil e uma faces. São Paulo: Galeria Olido, 2004. Disponível em: <http://www.carmelagross.com.br/ portu/depo2.asp?flg_Lingua=1\&cod_Depoimento=17>. Acesso em: $29 / 04 / 2013$

FERRARA, Lucrécia D'Alessio. Olhar periférico: informação, linguagem, percepção ambiental. São Paulo: Editora da Universidade de São Paulo, 1999.

FERREIRA, Aurélio Buarque de Holanda. Dicionário Aurélio. Rio de Janeiro: Nova Fronteira, 1975.

Minidicionário da língua

portuguesa. Rio de Janeiro: Nova Fronteira, 1993. 
FERREIRA, Glória; COTRIN, Cecília (org.). Escritos de artistas.

Rio de Janeiro: Jorge Zahar Editor, 2007.

FLORES, Laura González. Fotografia e pintura: dois meios diferentes? São Paulo: WMF Martins Fontes, 2011.

FLUSSER, Vilém. Filosofia da caixa preta: ensaios para uma futura filosofia da fotografia. São Paulo: Annablume, 2011.

O mundo codificado: por uma filosofia do design e da comunicação. São Paulo: Cosac Naify, 2007.

FOSTER, Hal. The ABCs of contemporary design. October 100, Spring 2002, pp. 191-199.

FOUCAULT, Michel. De outros espaços. 1984. Tradução de Pedro Moura. Disponível em: <http://www.virose.pt/vector/periferia/foucault_pt.

html >. Acesso em: 06/10/2013.

FRANCASTEL, Pierre. A realidade figurativa. São Paulo: Perspectiva, 1993.

GIANNOTTI, Marco. Breve história da pintura contemporânea. São Paulo: Claridade, 2009

\section{GUIMARÃES, Cao. Histórias do não ver. Rio de Janeiro: Cobogó, 2013.}

HASLAM, Andrew. O livro e o designer II: como criar e produzir livros.

São Paulo: Rosari, 2010

HELLER, Steven. The education of a graphic designer. New York:

Allworth Press, 1998.

HOFMANN, Armin. Graphic design manual: principles and practice. Sulgen: Niggli Verlag, 1965.

JUNIOR, Rubens Fernandes (org.). Geraldo de Barros: sobras mais fotoformas. São Paulo: Cosac Naify, 2006.

KLEE, Paul. Pedagogical sketchbook. London: Faber and Faber, 1981.
LAOZI. Dao de jing. São Paulo: Hedra, 2002.

LAPOUJADE, David. Potências do tempo. São Paulo: N-1 Edições, 2013.

LISPECTOR, Clarice. Água viva. Rio de Janeiro: Rocco, 1998a.

A paixão segundo G.H. Rio de Janeiro: Rocco, 1998b.

LORD, James. Um retrato de Giacometti. São Paulo: Iluminuras, 1998.

LUPTON, Ellen; PHILLIPS, Jennifer Cole. Novos fundamentos do design. São Paulo: Cosac Naify, 2008.

MANTOVANI, Anna. Cenografia. São Paulo: Ática, 1989.

MARZANO, Michela (org.). Dicionário do corpo. São Paulo: Edições Loyola, Centro Universitário São Camilo, 2012

MELVILLE, Herman. Bartleby, o escrivão. Uma história de Wall Street. São Paulo: Cosac Naify, 2005.

MONFORTE, Luiz Guimarães. Fotografia pensante. São Paulo: Senac, 1997.

MORAES, Sumaya Mattar. Descobrir as texturas da essência da terra: formação inicial e práxis criadora do professor de arte. São Paulo: Faculdade de Educação; Universidade de São Paulo, 2007. Tese de Doutorado.

MOSER, Benjamin. Clarice. São Paulo: Cosac Naify, 2009.

MOTTA, Flavio. Desenho e emancipação. In: Universidade de São Paulo. Faculdade de Arquitetura e Urbanismo. Desenho industrial e comunicação visual / Faculdade de Arquitetura e Urbanismo, Universidade de São Paulo. São Paulo: FAU-USP, 1970.

Textos informes. São Paulo: Faculdade de Arquitetura e Urbanismo da Universidade de São Paulo, 1971.

OSTROWER, Fayga. Criatividade e processos de criação. Petrópolis: Vozes, 2010. 
PAZ, Octavio. Marcel Duchamp ou o castelo da pureza. São Paulo: Perspectiva, 2008.

Signos em rotação. São Paulo: Perspectiva, 2005.

PEDROSA, Israel. O universo da cor. Rio de Janeiro: Senac Nacional, 2006.

PELBART, Peter Pál. A arte de viver nas linhas. In: DERDYK, Edith

(org.). Disegno. Desenho. Desígnio. São Paulo: Senac, 2007.

O avesso do niilismo: cartografias do esgotamento.

São Paulo: N-1 Edições, 2013.

PÉREZ, Carmen Lúcia Vidal. A lógica e o sentido da formação:

heterotopias, acontecimentos e sujeitos. Revista do Departamento de Psicologia UFF, v. 19, jan./jun. 2007.

PESSOA, Fernando. Ficções do interlúdio: poesias de Álvaro de Campos. Rio de Janeiro: Nova Fronteira, 1983.

\section{Letras, 2002.}

O livro do desassossego. São Paulo: Companhia das

RANCIÈRE, Jacques. O destino das imagens. Rio de Janeiro:

Contraponto, 2012.

RICHTER, Gerhard. Atlas. New York: D.A.P./Distributed Art

Publishers, 2011.

RILKE, Rainer Maria. Cartas a um jovem poeta e A canção de amor e de morte do porta-estandarte Cristóvão Rilke. São Paulo: Globo, 1999.

ROUILLÉ, André. A fotografia: entre documento e arte contemporânea. São Paulo: Senac, 2009.

SALLES, Cecília Almeida. Gesto inacabado: processo de criação artística. São Paulo: Fapesp: Annablume, 2004.

SAMAIN, Etienne. Como pensam as imagens. Campinas: Unicamp, 2012.
SANTOS, Milton. A natureza do espaço: técnica e tempo, razão e emoção. São Paulo: Edusp, 2004.

Da totalidade ao lugar. São Paulo: Editora da Universidade de São Paulo, 2005.

SARAIVA, Roberta. Saul Steinberg: as aventuras da linha. São Paulo: Instituto Moreira Salles e Pinacoteca do Estado de São Paulo, 2011.

SENNET, Richard. O artífice. Rio de Janeiro: Record, 2012.

SHONAGON, Sei. O livro de travesseiro. Porto Alegre: Escritos, 2008.

SONTAG, Susan. Sobre fotografia. São Paulo: Companhia das Letras, 2004.

TÀPIES, Antoni. A prática da arte. Lisboa: Edições Cotovia, 2002.

VALÉRY, Paul. Degas dança desenho. São Paulo: Cosac Naify, 2003.

Eupalinos ou o arquiteto. Rio de Janeiro: Editora 34, 2006.

VAN GOGH, Vincent. Cartas a Théo. Porto Alegre: L\&PM, 2002.

WARBURG, Aby. Der bilderatlas mnemosyne. Berlin: Akademie Verlag $\mathrm{GmbH}, 2003$.

WOOD, Paul. Arte conceitual. São Paulo: Cosac Naify, 2002.

\section{Filmes}

A caverna dos sonhos esquecidos. Werner Herzog. Canadá, EUA, França, Alemanha, Inglaterra, 2010.

Cosmópolis. David Cronenberg. Canadá, França, Itália, Portugal, 2012.

Pina. Wim Wenders. Alemanha, França, Inglaterra, 2011.

Um conto chinês. Sebastián Borensztein. Espanha, Argentina, 2011. 
